MARIANA GOMES MUSETTI MUNCK

CONCEPÇÕES ORGANIZACIONAIS E OS CONSTRANGIMENTOS AO PROCESSO DE FORMAÇÃO E APRENDIZAGEM: UM ESTUDO À LUZ DO AGIR ORGANIZACIONAL 
MARIANA GOMES MUSETTI MUNCK

\section{CONCEPÇÕES ORGANIZACIONAIS E OS CONSTRANGIMENTOS AO PROCESSO DE FORMAÇÃO E APRENDIZAGEM: UM ESTUDO À LUZ DO AGIR ORGANIZACIONAL}

Tese apresentada à Escola Politécnica da Universidade de São Paulo para a obtenção do título de Doutor em Engenharia de Produção.

Área de Concentração:

Engenharia de Produção 


\section{FICHA CATOLOGRÁFICA}

\section{Munck, Mariana Gomes Musetti}

Concepções organizacionais e os constrangimentos ao processo de formação e aprendizagem:

: um estudo à luz do agir organizacional / M.G.M. Munck. -São Paulo, 2009.

$148 \mathrm{p}$.

Tese (Doutorado) - Escola Politécnica da Universidade de São Paulo. Departamento de Engenharia de Produção.

1.Ergonomia no trabalho 2.Trabalho 3.Trabalho em grupo I.Universidade de São Paulo. Escola Politécnica. Departamento de Engenharia de Produção II.t. 


\section{CONCEPÇÕES ORGANIZACIONAIS E OS CONSTRANGIMENTOS AO PROCESSO DE FORMAÇÃO E APRENDIZAGEM: UM ESTUDO À LUZ DO AGIR ORGANIZACIONAL}

Tese apresentada à Escola Politécnica da Universidade de São Paulo para a obtenção do título de Doutor em Engenharia de Produção.

Área de Concentração:

Engenharia de Produção

COMISSÃO EXAMINADORA

Prof. Orientador Dr. Laerte Idal Sznelwar

Prof.

Prof.

São Paulo, de de 2009. 


\section{DEDICATÓRIA}

Dedico este trabalho a Deus e a minha família! 


\section{AGRADECIMENTOS}

- A Deus, por ter me propiciado a oportunidade de passar por esta experiência tão valiosa para a minha vida pessoal e profissional;

- Ao meu marido, companheiro de todas as horas, mesmo nas muitas dificuldades, sempre firme me apoiando nesta árdua, mas prazerosa caminhada. Não mediu esforços para me ajudar a concretizar este sonho, nunca me deixando desistir;

- Ao meu filho, Guilherme, que mesmo tão pequenino, sempre esteve do meu lado, me mostrando o valor da vida e me dando forças para lutar e vencer;

- Aos meus pais, por todo apoio e preocupação que dispensaram nestes longos anos;

- Ao Prof. Laerte Idal Sznelwar, meu orientador, minha eterna gratidão, pela enorme compreensão, apoio e acima de tudo pela sua bondade. Sem ele, este trabalho não existiria;

- A Dinorá e família, pela hospitalidade e apoio nos dias em que eu passei em São Paulo. Muito obrigada por sempre me receber tão bem na sua casa;

- Aos meus amigos e a todos que direta ou indiretamente sempre torceram e torcem pelo meu sucesso! 
O crescimento pessoal não pode ocorrer isoladamente. É através de interação com os outros que descobrimos a nós mesmos.

David Kolb 


\section{RESUMO}

As organizações se encontram em ambientes de gradativa competitividade. Conscientiza-se que as respostas a esse cenário passam pelas competências que renovam o aprendizado e por ele são renovadas. Pessoas competentes no sentido de inovar e lidar com imprevistos são cada vez mais exigidas em lugar de pessoas que respondam adequadamente a desafios previstos. Percebe-se que a estrutura e a forma de organizações adotadas favorecem ou prejudicam o aprendizado nessa direção. Este trabalho pretende evidenciar essa relação fazendo uso da perspectiva proposta por Maggi (2006), o agir organizacional, na qual as organizações são vistas como um processo de ações e decisões dinâmico e com possibilidades efetivas de intervenção por parte dos indivíduos. Antes, discutem-se três pontos de vista ou formas de ver a organização para analisar seus constrangimentos à aprendizagem e, conseqüentemente, suas conseqüências. Além disso, buscou-se relacionar os processos de cooperação e coordenação, bem como a coordenação do processo de desenvolvimento de ações em relação à formação. Temas como autonomia, discricionariedade, heteronomia e processo decisório permearam o estudo. Por fim, analisaram-se os constrangimentos que cada concepção de organização impõe sobre os processos de aprendizagem e, a partir daí, discutiu-se as contribuições do agir para a aprendizagem organizacional. Utilizourse como estratégia de pesquisa o estudo de caso, realizado em um hospital universitário, especificamente em sua diretoria de enfermagem, por apresentar características próximas da economia de serviços e que, por isso, exigiria a postura proposta pelo "agir organizacional". Os resultados demonstraram uma vinculação forte das práticas de aprendizagem, bem como das ações de formação com as características de formação apresentadas pelas diferentes concepções organizacionais apresentadas por Maggi (2006).

Palavras-chave: concepção organizacional; aprendizagem; constrangimentos; autonomia; coordenação de ações. 


\begin{abstract}
The corporations are in environments of gradual competitiveness. It has been assumed that the answers to this scenario pass through the competences that renew the learning and are renewed by it. Competent people in the sense of innovating and dealing with the unpredictable are more and more needed replacing those who answer adequately to the predictable challenges. It's apparent that the structure and the form of organization adopted favor or damage the learning towards this direction. This report intends to make this relation evident by using the perspective proposed by Maggi (2006), the organizational behaving, in which the organizations are seen as a dynamic process of actions and decisions and effective possibilities of intervention coming from the individuals. Before, it's discussed three points of view or forms of seeing the organization to analyze its embarrassments to the learning and, therefore, its consequences. Besides, it has been tried to relate the processes of cooperation and coordination, as well as the coordination of the developing of actions process in relation to the formation. Themes like autonomy, discretionarity, heteronomy, and decision process are within the study. At last, it has been analyzed the embarrassments that each conception of organization impose over the learning processes and, from there on, it has been discussed the contributions of the behaving in the organizational learning. It has been used as strategy of research the study of case, taken place at a university hospital, specifically in its nursing directory for presenting characteristics resembling to the economy of services and which, by its characteristics, would demand the positioning proposed by the "organizational behaving". The results demonstrated a strong relationship of the nursing practices, as well as the actions of formation with the actions of formation presented by the different organizational conceptions presented by Maggi (2006).
\end{abstract}

Keywords: Organizational conception; learning; autonomy; coordination of actions. 


\section{SUMÁRIO DE ILUSTRAÇÕES}

Quadro 1 - Os modelos de ação 70

Quadro 2 - Quatro modos de conversão do conhecimento 75

Figura 2 - Ciclo "observar-avaliar-projetar-implementar" (OADI) 78

Figura 3 - Modelo simples da aprendizagem individual: Ciclo OADI de modelos mentais individuais 79

Figura 4 - Modelo integrado de AO: ciclo OADI de modelos mentais compartilhados. 81

Quadro 3 - Condições necessárias ao processo de aprendizagem 90

Quadro 4 - Relações hipotéticas entre concepções e constrangimentos à aprendizagem_ 91

Quadro 5 - Protocolo dos Mecanismos (Instrumentos) de coleta de dados 96

Quadro 6 - Protocolo do Estudo de Caso 97

Quadro 7 - Relação de Entrevistados 99

Quadro 8 - Categorias e Unidades de Análise 104

Figura 5 - PROCESSO DE DIAGNÓSTICO DO DESENVOL VIMENTO DE PESSOAL 118

Figura 6 - ESQUEMA SIMPLIFICADO PARA A ELABORAÇÃO DE CURSO/TREINAMENTO 119

Figura 7 - ESQUEMA COMPLEXO PARA A ELABORAÇÃO DE CURSOS/TREINAMENTO 120

Quadro 9 - VISÃO GERAL DO CONTEXTO DE APRENDIZAGEM 136

Quadro 10 - CONSTRANGIMENTOS 137 


\section{SUMÁRIO}

1.) INTRODUÇÃO

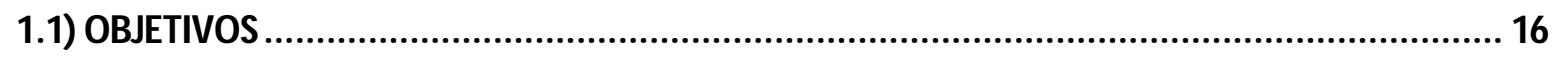

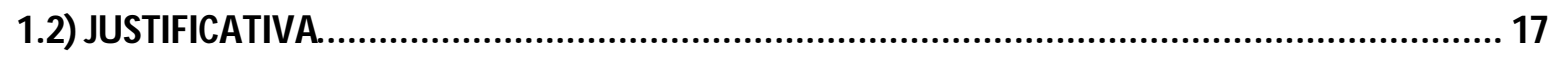

2.) $O$ ESTUDO DAS TEORIAS ORGANIZACIONAIS E OS FUNDAM ENTOS DO AGIR

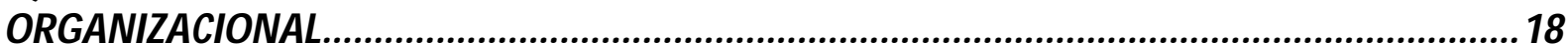

3.) CONCEPÇÃO DE ORGANIZAÇÃO COMO SISTEM A SOCIAL PRÉ-DETERM INADO ...............25

4.) CONCEPÇÃO DE ORGANIZAÇÃO COMO SISTEMA SOCIAL CONSTRUÍDO........................38

5.) CONCEPÇÃO DE ORGANIZAÇÃO COM O AGIR SOCIAL, COM O PROCESSO DE AÇÕES E

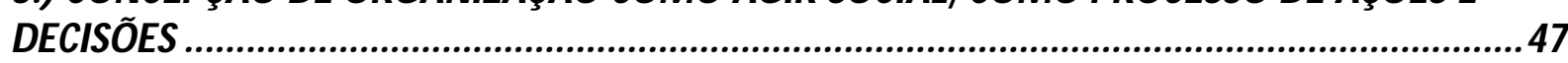

5.1) Níveis de Decisão e Modos de Regulação: A Autonomia e a Discricionariedade no Processo de Trabalho

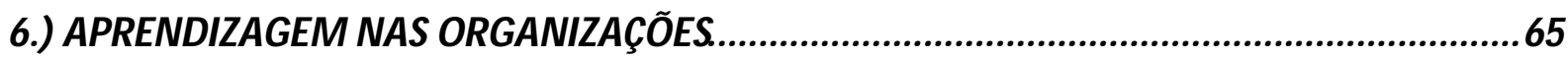

6.1) Aprendizagem Individual e Aprendizagem Organizacional............................................ 71

6.2) A Integração da Aprendizagem Individual e Organizacional ........................................... 78

6.3) Concepções Da Formação Na Perspectiva Do Agir Organizacional.................................. 82

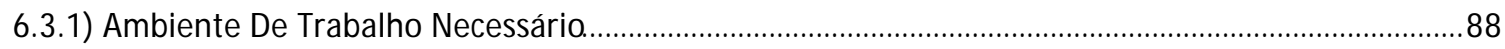

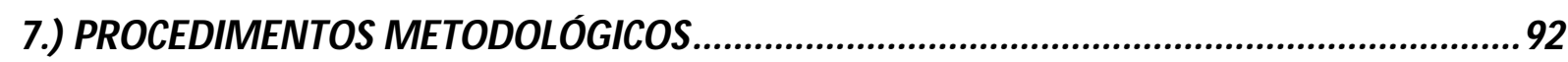

7.1) Detalhamento dos procedimentos metodológicos ................................................. 94

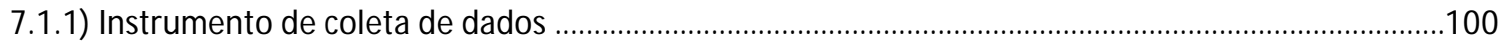

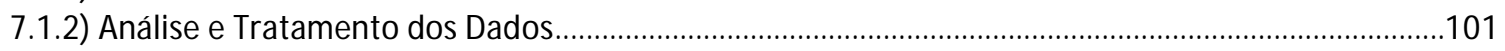

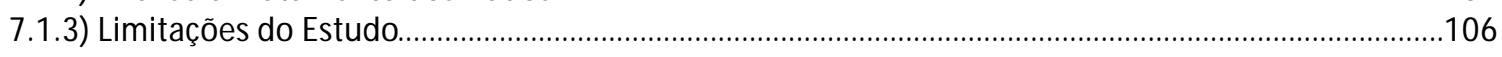

8. INTERPRETAÇÃO E ANÁLISE DOS DADOS....................................................108

8.1) Apresentação da Organização ..............................................................................108

8.2) Justificativa da Escolha do Hospital como objeto de estudo e da Diretoria de Enfermagem e sua Breve Descrição .................................................................................................110

8.3) Orientações Para a Definição de Treinamentos e Aperfeiçoamento de Pessoal ..................117

8.3.1) Programa De Treinamento Para Funcionário Recém-Admitido .........................................................121

8.3.2) Apresentação e Análise das Entrevistas.............................................................................................121

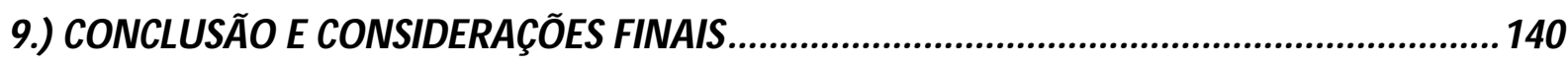

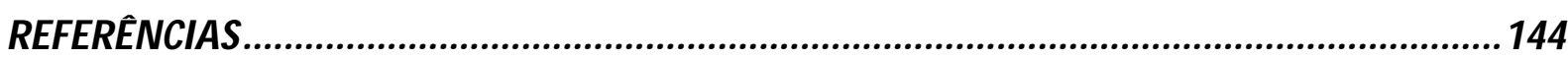

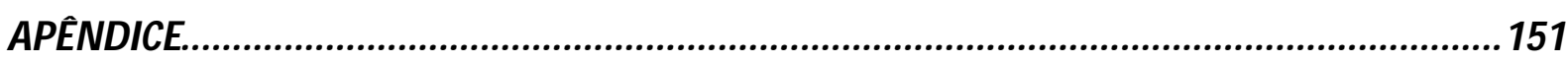

I - ROTEIRO NORTEADOR E DE CHECAGEM

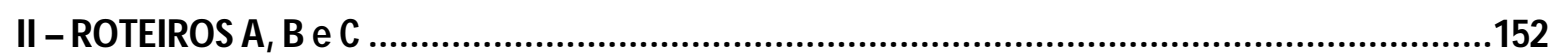

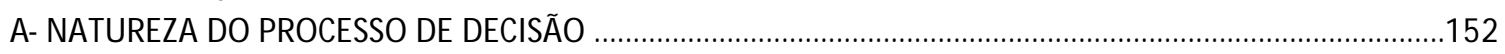

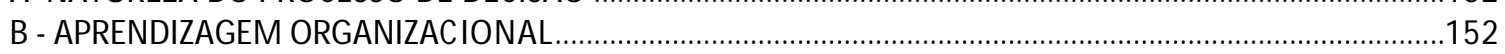

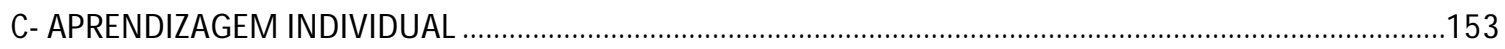




\section{1.) INTRODUÇÃO}

Mudanças significativas impostas ao mundo do trabalho provocam revisões nos modelos de gestão. Nbvas configurações buscam responder às necessárias variações nas rotinas de trabalho, colocando em "xeque" desenhos organizacionais rigidamente descritos e inflexíveis.

O surgimento das grandes empresas a partir da revolução industrial trouxe consigo grandes estruturas organizacionais que separaram o trabalho do trabalhador, delimitando claramente atividades e definindo o sujeito com capacidades físicas de realizá-las. As mesmas empresas também focavam suas ações no fluxo produtivo visando aumentar a produtividade por meio do incremento da velocidade das operações realizadas, no intuito de aumentar a quantidade produzida. Os processos eram desenhados para a constância, prescritos para não sofrer alterações de percurso, pois o ambiente competitivo à época era considerado estável.

Entretanto, os designs organizacionais pré-formatados que afastam 0 trabalho do trabalhador vêm cedendo lugar aos designs que criam possibilidades de ação autônoma do homem. Na mesma medida, a discussão de novos conceitos como evento, serviço e comunicação sugerem modificações no sentido da flexibilização, que seja capaz de atender ao ambiente altamente competitivo da chamada economia dos serviços, que substituirá em grande parte a chamada economia industrial. (ZARIFIAN, 2003)

A ocorrência de eventos (situações parcialmente imprevistas que perturbam o sistema produtivo); a velocidade crescente e necessária de inovações para manter clientes satisfeitos e a necessidade de comunicação irrestrita, características da economia de serviço, são elementos que demonstram a necessidade de maior interação entre trabalhadores, trabalho e modelos de gestão, para que interajam e haja acúmulo de aprendizado capaz de lidar com as adversidades inexoráveis do atual contexto das organizações. Classificar funcionários em postos de trabalho, com tarefas estritamente 
definidas, como ocorreu nos modelos do início do século passado e ainda presente hoje, implica em vários constrangimentos à aprendizagem.

$\mathrm{Na}$ chamada economia de serviços, onde o ambiente é dinâmico e passível de mudanças, há que se haver interferência recíproca entre funcionário e sistema. Para isso, o funcionário precisa entender seu trabalho e ser capaz, por meio de aprendizado constante, de nele interferir para assegurar respostas eficientes, não só às situações previstas, mas também frente aos eventos. Zarifian (2001) indica que todos devem trabalhar para satisfazer necessidades do cliente, ou seja, independente do posicionamento no processo (início ou fim), toda atividade é realizada para alcançar um resultado comum. Percebe-se também, além disso, que a diversidade nas atividades dos trabalhadores, excede as capacidades de um único indivíduo. O que exige equipes capazes de integrar conhecimentos e experiências. Segundo Zarifian (2003), o sucesso dessas ações conjuntas depende do entendimento recíproco e do compromisso com o grupo, aumentando a relevância da eficácia na comunicação.

Neste novo cenário, o trabalhador passa a ser visto como sujeito ativo e não mais delimitado pelas descrições do cargo, o conceito de competência ganha espaço. "Se reunirmos as mutações profundas do trabalho que os três conceitos: evento, comunicação e serviço, recobrem, veremos esboçar-se plenamente o conteúdo do que se pode entender por competência [...]" (ZARIFIAN, 2001; p. 55). Competência, segundo Maggi (2006) é a capacidade de saber avaliar a situação, as alternativas de resultado, a regulação das ações e suas relações e saber julgar a ação em relação ao processo, ou seja, competência está relacionada ao próprio trabalho e não pode ser dissociada dele. Contudo, isso somente será possível se forem quebradas as barreiras ao aprendizado. Boterf (2003) explica que cada ação do sujeito constitui-se em ação competente se ele fizer uso adequado dos recursos que dispõe. Reforça o autor, "apenas o profissional capaz de aprender com suas experiências é capaz de agir com competência".

Portanto, mostram-se indispensáveis ambientes de aprendizagem permanente, pois o próprio trabalho como uma atividade de aprendizagem 
necessita que sua organização envolva a liberdade para lidar com eventos, aprender com eles e daí satisfazer seus clientes. Para que a aprendizagem ocorra, segundo Kolb (1984) são necessárias algumas características dos sujeitos e do ambiente: disposição do sujeito em aprender e liberdade para realizar experimentações.

Percebe-se que cada ambiente de trabalho, com suas peculiaridades, proporciona ambientes distintos de aprendizagem, segundo Maggi (2006), isso ocorre porque a formação dos sujeitos é inevitavelmente concebida, realizada e interpretada segundo as perspectivas do sistema social na qual está inserida. Desse modo, cada organização, conforme concebida por seus gestores proporcionará diferentes ambientes de aprendizagem. Entender, tendo em vista os processos de formação, como são construídos os processos de cooperação e coordenação em relação ao tempo (estabilidade/mutabilidade) e à forma (homogeneidade/heterogeneidade); as ações técnicas e a coordenação das ações para o desenvolvimento de ações, bem como as ações que regulam as ações permite ampla visão dos fatores que constrangem a aprendizagem. Se a organização se produz pela produção de sua ordem: só é possível compreender o trabalho de organização abordando-o pela estruturação do processo, no caso, do processo de aprendizagem. Assim, respostas sobre: quais são as maneiras de ver a formação? Como se dá a busca do saber, do saber-fazer e do saber-ser? Eles estão voltados para quê? Como se dá a vinculação do que se aprende com a realidade operacional? Qual "sistema" predomina? São alvos deste estudo.

A referência para a compreensão dos diferentes ambientes proporcionados pelas diferentes visões organizacionais é 0 debate epistemológico das ciências sociais (MAGGI, op. cit.), despontando daí quatro maneiras de ver as organizações: lógica do sistema pré-construído: mecanicista e organicista, que percebe as organizações de forma prédeterminada, fundamentada nos preceitos positivistas; lógica do ator, que percebe as organizações descritas a posteriori, fundamentada no pensamento interacionista e fenomenológico; e o agir organizacional, o qual percebe as organizações como processos de ações e decisões, que admite tanto a 
prescrição (existência de regras pré-determinadas) quanto à descrição dos fenômenos depois de ocorridos.

As concepções organizacionais distinguem-se em termos da estrutura de organização do trabalho, natureza da autoridade e processos de decisão, a partir daí é possível identificar níveis de autonomia e discricionariedade e a heteronomia existentes na organização. Todavia, cada concepção, assim como proporciona direcionamentos aos processos de formação também proporciona constrangimentos. Portanto, é possível compreender como cada concepção em particular constrange a aprendizagem. Por constrangimento entende-se, segundo Maggi (2006) toda ação ou situação que dificulta a realização dos processos de aprendizagem, principalmente. Segundo Shuwartz (1998) podese impedir o movimento; a ação; a identificação com o trabalho; o pleno exercício das componentes cognitivas da atividade; a comunicação; o afeto, chegando até o "uso - de - si".

Numa lógica de prestação de serviços, na qual se insere um hospital, o processo de atendimento é moldado segundo a racionalidade da empresa, que impõe ao trabalhador aquilo que pode e aquilo que não pode ser feito. Contudo, a qualidade, exigida tanto pela empresa quanto pelo cliente, muitas vezes convida a uma ruptura com as regras estabelecidas dentro da racionalidade regente, que prioriza a lógica de colocação mercantil ou do fluxo, que ressaltam e supervalorizam parâmetros quantitativos. (Zarifian, 2001); (Arbix \& Sznelwar, 2002). A fronteira entre o que pode e o que não pode ser feito não é nítido. O que, em determinado momento pode ser sido tido como adequado para garantir a qualidade, em outro, pode ser contestado.

Considerando-se a importância da aprendizagem que permite trânsito frente à complexidade exigida em um hospital, tendo em vista a alteração da relação trabalho/trabalhador, antes, uma relação de subordinação, de submissão à regulação do trabalho e, atualmente, uma relação de recíproca interferência, percebe-se importante que o ambiente de trabalho proporcione condições adequadas ao desenvolvimento. Surge então a questão a ser respondida: como a construção e o desenvolvimento do agir estruturante 
(regulação de ações e decisões) impactam nos processos de formação e aprendizagem e vice-versa?

\section{1) OBJETIVOS}

GERAL

Analisar a construção e o desenvolvimento do agir estruturante, ou seja, os processos de regulação de ações e decisões, frente aos processos de formação e aprendizagem.

No intuito de desvelar o objeto da pesquisa e cumprir o objetivo geral, guiar-se-á pelos seguintes passos:

a) Explicar o processo de aprendizagem e seus respectivos constrangimentos em cada uma das concepções de organização sugeridas por Maggi (2006);

b) Descrever os processos de cooperação e coordenação em relação ao tempo (estabilidade/mutabilidade) e à forma (homogeneidade/heterogeneidade) no que tange à formação;

c) Descrever a coordenação das ações técnicas e a coordenação das ações para o desenvolvimento de ações, tendo em vista a formação.

d) Descrever como os sujeitos dominam o processo de trabalho frente à regulação de suas ações. (de forma discricionária, autônoma ou heterônoma?)

e) Organizar um quadro que ilustre as relações causais entre as concepções organizacionais e os constrangimentos à aprendizagem; 


\section{2) JUSTIFICATIVA}

Observa-se, tanto na instância acadêmica quanto empresarial, debates crescentes sobre os temas conhecimento, competência e aprendizagem. Os novos cenários macro-econômicos exigem novos perfis profissionais avessos aos perfis consolidados no século passado, pois a sobrevivência depende deles. Tomando-se a competência como a capacidade de agir satisfatoriamente frente a eventos e que ela exige tempo e direcionamento para se desenvolver, conforme Boterf (2003) e Zarifian (2001), ao se analisar o ambiente de trabalho em que ela é demandada, é possível identificar as limitações ou os constrangimentos à sua formação, tendo em vista o processo de aprendizagem que a precede. Essa informação permite uma reflexão sobre como as organizações, a partir da conscientização dos impactos de seu modelo de gestão na condução da formação, podem rever seus processos produtivos, no sentido de alinhá-los ao processo de aprendizagem, necessário para que existam as competências a elas necessárias.

Se, por um lado, é vantajoso para as organizações conhecerem os constrangimentos à aprendizagem, por outro, o próprio profissional terá a oportunidade de ampliar sua ação competente e aumentar seu valor social. Segundo Kolb (1984), o desenvolvimento pessoal depende do processo de aprendizagem. Apenas os sujeitos que realmente concluem o processo alcançam auto-realização, independência e auto-direcionamento, habilitandoos a julgar as situações de forma apropriada, lidar com dilemas e realizar novas contribuições para seu ambiente. Conforme ressalta Maggi (2006): as condições de formação de competência levam ao bem-estar dos trabalhadores.

Assim, este estudo pretende, sob a perspectiva prática, auxiliar as organizações na discussão sobre o direcionamento de seus processos de desenvolvimento, bem como possibilitar informações sobre maiores e melhores oportunidades de desenvolvimento aos próprios trabalhadores. Do ponto de vista acadêmico, almeja apresentar uma primeira discussão sobre as propostas de Maggi (2006), testando-as em uma realidade que, por princípio, exigiria o agir organizacional. 


\section{2.) O ESTUDO DAS TEORIAS ORGANIZACIONAIS E OS FUNDAMENTOS DO AGIR ORGANIZACIONAL}

Iniciar-se-á a explanação a partir das observações de Maggi (2006) e autores complementares, delimitando o caminho trilhado para se chegar à teoria do agir organizacional. Em seguida explorar-se-á o conceito de aprendizagem e sua função de adaptação ao meio, distinguindo duas categorias: a individual e a organizacional, baseando-se, essencialmente, nas obras de Kolb (1984); Nonaka e Takeuchi (1995); Kim (1998) e Maggi (2006).

REED (1999) expõe que a teoria da organização envolve um campo de conflitos históricos envolvido em um contexto social. Sugere que diferentes perspectivas podem ser organizadas não baseadas na visão histórica linear, como é praxe, mas em narrativas analíticas em torno da questão de como a organização pode e dever ser. As diferentes perspectivas abordadas pelo autor, tratadas como metanarrativas, envolvem: racionalidade, integração, mercado, poder, conhecimento e justiça; relacionadas, respectivamente, às problemáticas de ordem, consenso, liberdade, dominação, controle e participação.

Tais narrativas envolvem explicações rivais sobre conceitos de "atuação" e "estrutura", enfoques epistemológicos, "construtivismo" e "positivismo"; nível "local" em oposição ao nível "global" e, por último, "individualismo" e "coletivismo". O autor aponta também as supressões de maior significado que não são compreendidas nessas principais tradições narrativas, sendo elas: gênero, raça e etnicidade, tecnociência e desenvolvimento global e subdesenvolvimento.

No modelo de análise racional, início dos estudos das organizações, os autores partiam do princípio que a sociedade era regida por uma linha lógica e racional, e a organização era um instrumento racional utilizado para a solução de problemas coletivos, como pode ser visto nos trabalhos de Frederic Taylor nos Estados Unidos e de Henri Fayol na França, entre outros. Neste modelo, as técnicas usadas e os princípios epistemológicos tendiam a transformar 
preceitos normativos questionáveis em verdades absolutas e incontestáveis, exercendo profunda influência na forma de pensar dos estudiosos da organização.

Entretanto, alguns críticos do modelo racional começaram a questionar a incapacidade das organizações resolverem os problemas coletivos e de integração social. No fim dos anos 40 o modelo de integração começou a se firmar como modelo predominante na análise organizacional, baseando-se na teoria dos sistemas e no bem estar dos funcionários e da sociedade como fim.

Porém, o modelo de integração também apresentava seus vícios, e no final dos anos 60 também mostrou que as realidades sociais, econômicas e políticas não se ajustavam as teorias preconizadas. Ai surge o modelo do mercado, no qual uma onda neoliberal considera que os valores e interesses individuais e grupais se tornam irrelevante frente a uma estrutura de interesses do mercado, tido como impessoal.

Surge, então, o modelo de análise do poder, que não aceita 0 determinismo mercadológico e propõe uma análise baseada na sociologia de dominação de Weber. Nesse modelo, é analisado o movimento progressivo do poder dentro da organização, passando do confronto aberto e identificado à manipulação (bastidores) do dominante até chegar ao poder hegemônico.

O quinto modelo de análise é definido como "conhecimento", e se baseia nas redes instáveis de poder que se formam e se desfazem dentro das organizações fundamentadas no conhecimento dos grupos, colocando o papel central no conhecimento e no poder que ele potencialmente confere ao seu detentor. Esse modelo passa da análise organizacional de nível macro para um nível de análise micro.

Os modelos anteriores não apresentavam resposta para questões importantes como ética, justiça, igualdade, democracia e suscitaram debates sobre as perspectivas imediatas e mediatas da ameaça à liberdade e democracia nas estruturas organizacionais burocráticas e controladoras. $O$ que contribuiu para o surgimento do modelo baseado na justiça. 
Ao redor dessas seis estruturas ou modelos de análise organizacional, vários temas interligados são abordados, mostrando a contestabilidade das teorias. O debate atuação/estrutura mostra que os pesquisadores que trabalham com os modelos racionais, de integração e de mercado preferem a visão estrutural da organização, enquanto aqueles que utilizam os modelos de poder, conhecimento e justiça adotam o conceito de atuação organizacional. $\mathrm{Na}$ mesma linha seguem os debates construtivista/positivista, local/global, individualista/coletivista, mostrando claramente os diferentes paradigmas adotados pelas linhas de conhecimento.

Reed (1999) também ressalta alguns pontos de exclusão, não devida e abrangentemente tratados pelos trabalhos científicos na área organizacional, mas que certamente exercem influência nas dinâmicas organizacionais, a saber: a questão do gênero, da etnicidade, da tecnociência e da globalização política, econômica e cultural. Por fim, aborda-se a polarização inconciliável dos modelos ortodoxos versus os modelos relativistas radicais como uma alternativa atraente e uma saída para esse conflituoso campo intelectual.

Burrell e Morgam (2006) auxiliam no entendimento e posicionamento dos estudos organizacionais ao proporem um quadro constituído por dois extremos de cada um dos quatro pressupostos: Nominalismo/Realismo no debate ontológico; Anti-positivismo/Positivismo no debate epistemológico; Voluntarismo/Determinismo no debate sobre a natureza humana; Ideográfico/Nomotético no debate metodológico. O nominalismo considera que o mundo social externo ao indivíduo, não é mais que nomes, conceitos e rótulos, enquanto que o realismo considera esse mundo real, tangível e com estruturas imutáveis. O positivismo procura explicar e predizer o que acontece no mundo social procurando regularidades e relações de causas entre seus elementos, enquanto que 0 anti-positivismo rejeita o ponto de vista de observador que caracteriza o positivismo, sendo que a compreensão somente pode ocorrer quando se considera a participação do observador na ação. $O$ determinismo considera que o homem e suas atividades são completamente determinados pela situação ou ambiente, enquanto que na visão do voluntarismo o homem é completamente autônomo e possui livre-arbítrio. A 
ideografia considera que somente é possível compreender o mundo social se houver conhecimento detalhado do assunto investigado, enquanto que o nomotético enfatiza a importância de basear a pesquisa em protocolos sistemáticos e técnicas. Burrell e Morgan, para fins de conveniência, referemse aos dois extremos apresentados em cada pressuposto em subjetivo e objetivo.

Burrell e Morgan (2006, p.22), em contribuição aos estudos das organizações, expõem então quadro paradigmas que influenciam a forma de vê-las e interpretá-las. Na década de 1960, existiu um forte debate em relação à sociologia da regulação e da mudança radical, surgindo um espaço para as dimensões subjetivas e objetivas. Dessa forma essas quatro posições, definem o que o autor chama de paradigmas sociológicos que podem ser utilizados para analisar diferentes teorias sociais, e eles são: "humanista radical", "estruturalista", "interpretativo" e "funcionalista", quais sejam:

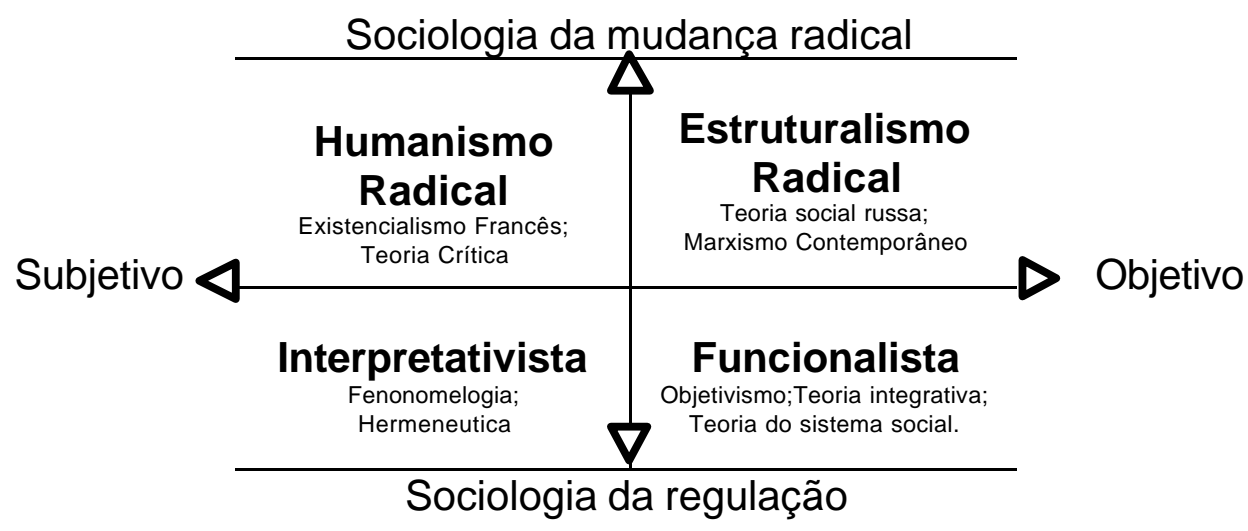

Figura 1 - Paradigmas - adaptada de BURREL e MORGAN, 2006, p.29

As diferentes epistemologias, modelos de natureza, levam cientistas a diferentes metodologias. Porém, destaca-se que o principal interesse é com o entendimento da forma que cada indivíduo cria, modifica e interpreta o mundo em que ele ou ela se encontra. A ênfase em casos extremos tem de ser colocados à explanação e entendimento do quê é único e particular ao indivíduo ao invés do que é geral e universal. Descrevem-se, a seguir, cada um deles. 
Funcionalista - com características da sociologia da regulação e do objetivismo, com influências positivistas, realistas, deterministas e nomotéticas. Tem como características explanar sobre o status quo, a ordem social, o consenso, a integração social, a solidariedade e a satisfação das necessidades. Busca soluções práticas para problemas práticos de forma a regular e controlar os relacionamentos. As relações podem ser identificadas, estudadas e mensuradas, os fatos sociais existem fora da consciência humana e retrata as atividades do dia a dia.

Interpretativista - com características da sociologia da regulação e do subjetivismo - com influências nominalistas, anti-positivistas, voluntaristas e ideográficas. Compreende o universo como ele é. Busca a compreensão da natureza fundamental do universo social através da experiência subjetiva. A realidade social existe fora da consciência exterior de cada indivíduo, a regulamentação é mais implícita do que explícita. Desafia os padrões assumidos pelos funcionalistas em suas pesquisas.

Humanismo Radical - com características da sociologia da mudança radical e do subje tivismo - tem como características a importância de superar ou transcender as limitações dos arranjos sociais existentes, a consciência do homem é dominada pelas superestruturas com as quais ele interage e nas quais forma o conhecimento de si mesmo e a sua própria consciência. Tende a enxergar a sociedade como anti-humana. Busca compreender os constrangimentos impostos para alcançar o desenvolvimento máximo. Enfatiza a mudança, os modos de dominação, as formas de emancipação, as privações e o potencial.

Estruturalismo radical - com características da sociologia da mudança radical e do objetivismo - com influência epistemológica marxista e weberiana, tem como características: a teoria funcionalista, foca a consciência como a base para a crítica radical da sociedade, a mudança radical é construída nas estruturas e na natureza da sociedade contemporânea, o papel das diferentes forças sociais atuam como significado da explicação de mudanças sociais, a sociedade contemporânea é caracterizada por conflitos fundamentais que geram mudanças radicais no pensamento, na economia e na política. 
Sustenta que os conflitos sociais são fundamentais para gerar mudanças radicais através de crises políticas e econômicas e, conseqüentemente, a emancipação do homem e da estrutura social na qual eles vivem.

Os paradigmas definem quatro visões do universo social baseados em diferentes conceitos meta-narrativa que regem a natureza da ciência e da sociedade. As junções dos quatro paradigmas originam um mapa que colabora na identificação de bases similares e opostas entre o trabalho de vários pesquisadores e as perspectivas e abordagens utilizadas, isso permite melhor compreender e analisar a realidade de seus estudos. A maneira de conceber a racionalidade é imprescindível para avaliar diferentes abordagens, tanto às escolhas teóricas, quanto às opções epistemológicas.

Nesse contexto, Maggi (2006, p.1-4), oriundo de estudos da filosofia e da sociologia, quando iniciou estudos sobre a organização e sobre o trabalho, teve a impressão de encontrar uma área em aberto. Na década de 1970 a literatura internacional que tratava dos estudos organizacionais, destacava a existência de diferentes teorias em oposição, até mesmo em disputa, que dificultava a orientação de novos estudos. Contudo, o autor encontrou convergências entre as diferentes contribuições teóricas disciplinares ao concluir que as divergências não advinham de disciplinas, mas sim de abordagens. O que o levou a buscar uma epistemologia da organização, que o levou a referenciar a epistemologia das ciências humanas e sociais.

Concluiu que existia uma incompletude nas preocupações metodológicas da literatura sobre a organização, que estava muito centrada no debate entre explicar e compreender, e vislumbrou a necessidade de uma terceira via epistemológica. Considerou quatro lógicas organizacionais que permeiam os sistemas de gestão. Essas lógicas foram identificadas por Maggi (2006), fazendo referência a diferentes epistemologias da organização existentes, que, segundo o autor, correspondem às epistemologias utilizadas pelas ciências humanas e sociais. Epistemologia é o estudo do conhecimento, de sua origem e de seus limites, caracterizando uma "maneira de ver o mundo". Conforme a visão adotada, Maggi (2006) explica que há diferentes concepções das organizações: “(...) vias epistemológicas se refletem 
inevitavelmente nas maneiras de ver a organização - como aliás em qualquer outro campo de estudo das ciências humanas e sociais" (p.19). Parte, portanto, de três diferentes vias epistemológicas, o positivismo, a fenomenologia e a terceira via que busca o equilíbrio entre as outras duas, resultante do Methodenstreit - "debate sobre os métodos". A partir destas formas de ver o mundo, pode-se caracterizar as concepções das organizações que, ainda segundo Maggi (op. cit, p.19) são: concepção de organização como sistema social pré-determinado; concepção de organização como sistema social construído; concepção de organização como agir social, como processo de ações e decisões. 


\section{3.) CONCEPÇÃO DE ORGANIZAÇÃO COMO SISTEMA SOCIAL PRÉ-DETERMINADO}

Esta concepção se divide em abordagem mecanicista e organicista.

O sistema mecanicista tem como base a racionalização dos processos e a preocupação em alcançar a eficiência máxima a partir do conhecimento das relações causais existentes. Trata-se de uma associação entre a forma de ver uma organização e a forma de ver uma máquina, na qual cada peça tem sua função e mantém relações diretas com as demais para alcançar os objetivos determinados pelo seu projetista. Esta lógica tem início destacado nos estudos da organização durante a Revolução Industrial, causando grande impacto na mecanização da indústria e dos processos produtivos, resultando nas correntes teóricas que guiariam a administração no início do século XX e que mantêm forte influência até a época atual. Entre os principais autores desta lógica temse Taylor (1990) e Fayol (1970).

Seguindo pressupostos positivistas, considera as organizações como uma sociedade humana em parâmetros reduzidos, portanto, elas também são regidas por leis causais assim como os demais fenômenos naturais. Daí surge a crença de que estudos aprofundados dessas relações causais resultariam na identificação de processos que alcançam a produtividade máxima possível, definindo-se exatamente toda atividade que deve ser realizada e como deve ser realizada.

Assim, todas as variáveis observadas em uma situação podem ser analisadas de forma imparcial e objetiva, inclusive o fator "homem". Acredita-se que o ser humano, visto como ser racional, sempre busca maximizar seu rendimento (lucro) e minimizar seus gastos, mantendo constante sua preocupação econômica. Têm-se assim o conceito de Homo economicus que, segundo Rossetti (2003), é aquele que tem um comportamento racional, sempre buscando a maximização de seus rendimentos e de sua satisfação. Simon (1997) explica que alguns estudiosos atribuem ao homem econômico 
uma onisciência racional extrema, tornando-o capaz de analisar todas as alternativas possíveis e escolher a que certamente trará melhores resultados. Isto legitima a adoção do best way, já que as organizações, compostas por homens econômicos, também devem ser capazes de optar pela alternativa que maximize seus ganhos, ou seja, que permita a produtividade máxima.

A partir do momento que se delega a especialista a análise e definição da forma certa de realizar as atividades, o trabalhador passa a ser visto como um cumpridor de tarefas pré-definidas, impostas por seus superiores. Por isso, no sistema mecanicista, a figura de um supervisor ou de um chefe de departamento que instrua seus operários é imprescindível. Isso pode ser evidenciado nas palavras de Taylor:

A ciência que estuda a ação dos trabalhadores é tão vasta e complicada que o operário é incapaz de compreender esta ciência sem a orientação de chefes, quer por falta de instrução, quer por capacidade mental insuficiente. (TAYLOR, 1990, p. 41)

Neste ambiente, torna-se essencial o controle e a concentração de poder do processo de decisão para assegurar que o trabalho seja realizado pelos trabalhadores conforme o planejado pelos projetistas. Segundo Fayol (apud MOTTA e VASCONCELLOS, 2006), o ideal é um supervisor seguindo detalhadamente o trabalho dos subordinados, acompanhando o cumprimento específico das normas para alcançar a produtividade máxima. Assim, a organização deve ser planejada por projetistas detalhadamente e, depois, passadas as coordenadas aos trabalhadores, acompanhando-os e assegurando que as normas definidas estão sendo respeitadas.

Problemas de produtividade não são vistos como relacionados ao elemento humano, mas sim como necessidade de aperfeiçoamento do sistema, que deve ser providenciado pelos projetistas, nunca pelos próprios trabalhadores. Entretanto, para evitar que os trabalhadores prejudiquem o sistema, considerado eficiente e eficaz, faz-se uso de premiações e punições, com critérios monetários, visto que o trabalhador é classificado pelos gestores desta lógica como Homo economicus. As organizações são vistas como estruturas independentes dos sujeitos que a compõem, sendo definidas previamente. 
(...) o sistema [mecanicista] é compreendido como uma entidade prédeterminada em relação aos sujeitos, ao seu ser no sistema, e ao seu agir. Os sujeitos singulares podem mudar, entrar no sistema ou sair dele, sem mudar a identidade deste, pois esta é independente da identidade dos sujeitos. (MAGGI, 2006, p.172)

Os trabalhadores não precisam preocupar-se em adequar novos métodos às suas operações ou buscar formas mais eficientes de realizá-las, visto que isto é função do projetista (arquiteto do sistema), cabe a eles apenas cumprir as funções determinadas: respeitar a rotina e seguir os procedimentos padronizados. A organização do trabalho é baseada na divisão do trabalho, separando o planejamento da realização do trabalho (trabalhadores $x$ projetistas), decompondo a operação total em partes ou tarefas simples (LIKERT, 1979). Segundo Sznelwar e Mascia (1998), estudos têm demonstrado que essa lógica leva os trabalhadores a situações em que são obrigados a restringir até mesmo a liberdade de seus movimentos. O posto de trabalho geralmente é inadequado, os movimentos são dificultados pelas impossibilidades de ajustes e, além disso, durante horas deve-se permanecer fixo e imobilizado no mesmo local.

Concluindo, tem-se como principais características da lógica mecanicista a crença na racionalidade absoluta e na possibilidade de alcançar-se a eficiência máxima. Para isso, faz uso da especialização do trabalho, delegando aos projetistas a tarefa de estruturar toda a organização, criando rotinas simples de serem realizadas pelos trabalhadores, com uma clara divisão das tarefas e uma forte presença de chefes para acompanhar e controlar as atividades, mantendo o ambiente estável. Cabe aos chefes o processo de decisão, dentro dos limites definidos pelos projetistas, restando aos trabalhadores apenas a obediência e respeito às regras definidas. Essa divisão do trabalho também auxilia na manutenção do foco de cada trabalhador em sua própria atividade, evitando confraternizações nos horários de trabalho ou troca de informações vistas como desnecessárias pela organização entre os trabalhadores.

Como já salientado por Maggi (2006), o processo de formação dos colaboradores de uma organização é concebido conforme a lógica preponderante do modelo de gestão, constituindo-se um elemento próprio dele. 
Portanto, podemos descrever o processo de formação com suas características inerentes ao sistema mecanicista. Sem maiores explicações, é fácil compreender que, sendo a obediência e o respeito às regras o único comportamento esperado dos trabalhadores para manter a ordem estabelecida previamente pelos projetistas e alcançar a produtividade máxima, o conhecimento necessário para se realizar uma atividade encontra-se nas regras definidas. É preciso adaptar os trabalhadores ao sistema, começando pela aceitação dos objetivos e modos de funcionamento do sistema, bem como o reconhecimento da estabilidade das relações e hierarquia. (MAGGI, 2006)

O treinamento de novos trabalhadores consiste na explicação da tarefa a ser realizada, de forma simples e rápida, fornecendo informações práticas e sem esclarecimentos sobre o porquê dela ser realizada. Ademais, apenas a tarefa que será de responsabilidade do trabalhador faz parte do treinamento, as demais atividades da organização não são explicadas por não haver necessidade, basta ao funcionário saber sobre seu próprio trabalho e cumpri-lo adequadamente.

Este processo de formação ocorre fora do ambiente de trabalho, previamente a ele, utilizando uma metodologia de aprendizagem passiva, ou seja, o "aluno" mantém-se em posição de simples escuta e respeito às instruções que está recebendo de seu instrutor, alguém delegado pelos projetistas da organização e possuidor do conhecimento que será passado ao novato.

Os programas de formação são definidos através de uma lista de instruções e prescrições de funcionamento, criada a partir das descrições de cargos e funções. Assim, para cada cargo, com suas respectivas atividades, há um programa de treinamento específico para 0 ingressante, seguido rigidamente. Considerando-se 0 ambiente estável das organizações mecanicistas, visto que os processos mantêm-se constantes e sem variações, não há necessidade de outros treinamentos além do inicial, a menos que os projetistas decidam alterar as normas e as funções dos cargos vigentes.

A formação, então, é vista como um meio de adaptação e condicionamento dos sujeitos às necessidades da organização, sendo 
classificada em duas partes: o treinamento, no qual são passadas as instruções sobre o trabalho que deverão ser seguidas exatamente, e a repetição da atividade, já que, quanto mais vezes o sujeito realizar determinada atividade, melhor será sua habilidade relacionada à ela. (MAGGI, 2006)

A avaliação dos resultados do processo de formação se dá através da verificação da conformidade entre o comportamento esperado do operário, segundo as normas e prescrições, e o comportamento real. Quanto mais semelhantes estes dois comportamentos, maior a eficácia alcançada pelo treinamento.

Um fator necessário à aprendizagem, segundo Kolb (1984) é a ausência de sua imposição por superiores, valorizando o apelo vital, "por que" e "para quê" aprender. Entretanto, o processo de aprendizagem nas organizações mecanicistas é definido previamente por seus projetistas, que tem como principal preocupação alcançar a eficiência máxima, ou seja, adaptar os sujeitos ao sistema de modo que todo o seu potencial previsto seja obtido.

Além do extremo respeito à divisão e especialização do trabalho, os sujeitos devem manter suas atividades dentro dos padrões previamente definidos, visto que cabe apenas aos projetistas alterar o trabalho realizado, havendo punições aos desvios cometidos. Assim, mantém-se um ambiente que valoriza a rotina criada previamente e restringe a possibilidade de novas experiências. De fato, neste ambiente não se pode falar em aprendizagem individual dos trabalhadores porque este conceito implica em criação de conhecimento e, na lógica mecanicista, apenas os projetistas criam conhecimento enquanto os demais são limitados ao desenvolvimento de habilidades por meio de sua repetição. A rotina instituída dificulta em especial a fase de experimentação ativa do "aprendido" por limitar suas atividades às instruções recebidas, não havendo autonomia, resta a opção de respeitar as normas e rotinas estabelecidas pelos projetistas.

Por fim, deve-se destacar o constrangimento que surge do isolamento de cada sujeito em sua atividade. Na concepção mecanicista, cada sujeito deve dedicar-se completamente ao seu trabalho, evitando confraternizações e conversas durante a sua realização. Isso inibe o processo de feedback entre os 
sujeitos e o apoio de pessoas que não estão envolvidas diretamente na atividade pois restringe a comunicação entre os trabalhadores.

É preciso lembrar que todo conhecimento é criado a partir da aprendizagem individual e, portanto, a aprendizagem organizacional depende diretamente da aprendizagem dos sujeitos individuais. Na lógica mecanicista, como existem diversos constrangimentos à aprendizagem individual, não se permite dizer que os trabalhadores de uma organização mecanicista estejam em constante processo de aprendizagem individual, caracterizando assim um constrangimento à aprendizagem organizacional.

O processo de aprendizagem organizacional depende da troca de informação entre os sujeitos, seja de forma explícita (falada ou escrita) ou implícita (observação, compartilhamento de experiências), conforme a característica do conhecimento que pode ser classificado em explícito ou tácito (NONAKA e TAKEUCHI, 1995). Os processos são previamente definidos pelos projetistas, o que inclui os meios de comunicação. Assim, não há liberdade para o sujeito expressar-se da maneira mais adequada conforme seu entendimento, mas apenas conforme o modelo instituído que se refere predominantemente aos conhecimentos explícitos, ou seja, normas e regras. A interação dos sujeitos também é prejudicada pois, além deles serem focados em suas próprias atividades, os canais de comunicação instituídos, normalmente envolvendo os superiores, dificulta ainda mais a troca de informação entre colegas de trabalho.

A divisão do trabalho ainda dificulta a socialização, processo no qual um sujeito transmite seu conhecimento tácito a outro, que o adquire também de forma tácita. Para que a socialização ocorra, é preciso que os sujeitos interajam, tenham a possibilidade de observar o trabalho de seus colegas e a liberdade de tentar realizar sua atividade de forma semelhante à maneira de trabalhar que fora observada.

Segundo Nonaka e Takeuchi (1995), também é necessário ao processo de aprendizagem organizacional a redundância das informações, ou seja, que todos os sujeitos compartilhem informações, mesmo que, em um primeiro momento, os indivíduos não precisem dela. A estrutura de divisão do trabalho, 
além de dificultar o fluxo de informação, ainda constrange a reflexão coletiva sobre as experiências vividas. Primeiro, porque não há disponibilidade dos sujeitos para a reflexão individual, como já citado como constrangimento à aprendizagem individual; segundo, ainda que houvesse reflexão individual, esta não poderia ser ampliada à reflexão coletiva devido à falta de meios ativos de comunicação entre os trabalhadores e as constantes restrições à troca de informações entre eles.

Outro constrangimento identificado refere-se ao caos criativo, que corresponde à vivência de circunstâncias incertas e quebras de rotina, levando os sujeitos a refletir e rever os conceitos adotados. A dificuldade encontra-se no fato de a lógica mecanicista prezar pela estabilidade de seu sistema a partir de tarefas repetitivas e sem imprevistos. A atividade de cada sujeito é delimitada de modo que seu trabalho seja simples e não tenha que lidar com situações adversas, cabendo aos projetistas adequar o sistema para evitar os imprevistos e corrigir os problemas existentes. Caso ocorram imprevistos, o trabalhador não tem autonomia para resolvê-los, sua função frente a esta situação é comunicar ao seu superior, repassando as informações aos projetistas para que eles resolvam o problema.

Assim como a lógica mecanicista, a lógica organicista vê a organização como pré-determinada ao sujeito, utilizando a abordagem positivista para alcançar a eficiência máxima. As duas lógicas divergem, entretanto, em dois pontos: o fator humano e a interação com o ambiente.

Enquanto o homem é objetivo e age estritamente conforme as normas, no sistema mecanicista, visando alcançar a maior recompensa monetária, para a organicista, o homem deve ser tratado como um indivíduo com necessidades e desejos que interferem diretamente em sua capacidade de agir objetivamente, que nem sempre prefere a recompensa monetária à social.

Assim como há as recompensas e punições para os trabalhadores provenientes da estrutura organizacional (através de questões monetárias), conforme seu comportamento em relação às normas oficiais, também há recompensas e punições provenientes dos próprios trabalhadores para aqueles que se adequarem ou não ao comportamento esperado pelo grupo. Blau e 
Scott (1970) exemplificam: a participação de jogos e/ou rodas de conversas durante os intervalos de trabalho demonstra quem é aceito e tem status pelos companheiros e quem está renegado ao ostracismo. Esta situação pode ocorrer devido à produtividade do funcionário, sendo aqueles que produzem de mais ou de menos excluídos pelo grupo.

Motta e Vasconcelos (2006) afirmam que ao tratar os operários como indivíduo que podem ser influenciados pelo grupo e que tem necessidades e desejos sociais além dos materiais, o conceito de Homo economicus discutido pelos mecanicistas precisa ser revisto. Para os organicistas, o homem deve ser considerado como homo socialis, ou seja, um homem social que não se satisfaz apenas com recompensas materiais (monetárias) e que precisa se sentir realizado em seu trabalho. Este homem segue regras estabelecidas pelo grupo de trabalho para poder satisfazer suas necessidades sociais, tais como participar de uma roda de conversa no horário de almoço, como exemplificados por Blau e Scott (1970).

A correlação direta entre organização e ambiente ainda ressalta a importância do feedback para manter o sistema funcionando adequadamente. Sendo toda organização um sistema aberto, ela está em interação e intercâmbio contínuo com seu ambiente, o processo de retroalimentação (feedback) fornece as informações necessárias para identificar se os produtos do processo do sistema (outputs) estão adequados e satisfazendo as necessidades do mesmo. Caso algum problema ocorra, cabe à organização rever seus inputs (importações do ambiente) e seus processos de transformação (throughputs).

A lógica organicista, apesar de ser criada a priori, não é estática, não comporta rigidezes de coordenação e não trabalha com uma única maneira certa, diferente do best way taylorista e dos demais princípios da lógica mecanicista (MAGGI, 2006).

Por considerar os anseios e desejos dos trabalhadores como uma fonte de variações do processo de trabalho, interferindo no sistema previamente definido pelos projetistas, a lógica organicista entende a motivação como uma 
ferramenta importante ao desenvolvimento de seus colaboradores e considera como parte do trabalho as relações inter-pessoais surgidas nele.

A participação dos trabalhadores no processo de decisão é vista como importante por dois aspectos: o aumento do comprometimento e envolvimento dos colaboradores, visto que a participação no processo de decisão tende a originar um maior empenho em concretizá-la; e a superioridade da qualidade técnica das decisões tomadas, já que em toda organização existem inúmeras peculiaridades na tarefa de cada pessoa que a alta ou média administração jamais poderia compreender tão bem quanto o próprio responsável pelo serviço.

É importante ressaltar que a abordagem organicista mantém uma hierarquia definida assim como a mecanicista, designando as posições sociais e as funções que cada colaborador deve respeitar. A questão que se quer descrever aqui é a flexibilidade existente em cada função, a discricionariedade que permite afastamentos e correções do programa previamente instituído pelos projetistas da organização. A mudança organizacional ainda é compreendida aqui como tarefa para especialistas, cabendo aos trabalhadores apenas decisões de menor impacto estrutural, que não alteram a organização em seus fundamentos e processos, mas apenas asseguram uma melhor adequação das atividades às necessidades tanto do ambiente quanto do sujeito.

Assim, a lógica organicista apenas permite espaços discricionários aos seus sujeitos visto que eles devem agir dentro dos padrões definidos previamente pelos projetistas, a discricionariedade serve para equilibrar 0 sistema projetado frente às variações do ambiente não prevista devido a limitações do projeto e incertezas existentes no ambiente organizacional.

Em suma, têm-se como principais características da lógica organicista a mesma crença que a lógica mecanicista tem na objetividade do trabalho, com uma diferença: ver o homem como um ser social, considerando que as relações humanas podem interferir no trabalho. Para satisfazer as necessidades sociais dos trabalhadores, o contato entre eles é favorecido, sendo o trabalho em equipe a melhor opção para a organização, além de 
assegurar que todos tenham conhecimento do por que na atividade que realizam e de sua importância. Por esta lógica, percebe-se que a relação da organização com o ambiente é instável e as definições dos projetistas precisam ser adaptadas conforme as necessidades, possibilitando discricionariedade aos sujeitos. A opinião dos trabalhadores é considerada aqui uma fonte de informação aos projetistas, valendo como um feedback sobre o funcionamento do sistema projetado.

A lógica organicista põe ênfase nas relações inter-pessoais, visando a satisfação das necessidades e a melhor adequação ao ambiente externo. Sendo a perspectiva da formação e da aprendizagem correspondente à lógica adotada pela organização, a formação dos colaboradores na lógica organicista também terá ênfase nos relacionamentos inter-pessoais.

Então, o principal objetivo da formação nesta lógica é ativar, estimular e orientar as motivações e expectativas dos sujeitos em função das necessidades do sistema. $O$ envolvimento dos trabalhadores com a organização é tido como fator fundamental ao bom desenvolvimento das atividades, assegurando boas relações inter-pessoais e interesse em tomar decisões dentro dos espaços discricionários. Além disso, a integração é valorizada em um ambiente com trabalhadores envolvidos, o que é importante, pois Blau e Scott (1970) mostram em seu estudo que grupos coesos e com objetivos em harmonia com os objetivos da organização alcançam os melhores resultados possíveis - diferentemente do que ocorre com grupos de baixa coesão ou grupos coesos em conflito com os objetivos organizacionais.

Este processo de aprendizagem não corresponde a um treinamento para tarefas específicas, como ocorre na lógica do sistema mecanicista, mas um desenvolvimento do conhecimento que o sujeito tem de si próprio, do papel que desempenha e da rede de papéis em que está inserido. Por papel entendemos o conjunto de comportamentos esperados associados com um trabalho específico e com funções ou posições extrínsecas a um trabalho, podendo um membro desempenhar vários papéis e vários membros desempenharem 0 mesmo papel (BENNE e SHEATS, apud SOTO, 2005). 
A formação ocorre em sala de aula, ou seja, em um ambiente fora do próprio trabalho, utilizando métodos didáticos "ativos", segundo Maggi (2006), e de estimulação para a prospecção, análise e solução dos problemas. Trata-se da utilização da experiência já adquirida pelo sujeito para incrementar o processo de integração e adaptação do trabalho, partindo das necessidades levantadas pelos próprios sujeitos. Isto significa que não há uma planificação prévia da formação e sim um levantamento da demanda e, conforme for preciso, projetos de formação. Os destinatários da formação, assim sendo, são os sujeitos que demonstram necessidades e os formadores serão sujeitos que desempenham como papel particular a integração.

A obtenção dos resultados do processo de formação vem da medição de satisfação dos sujeitos. Em suma, visa garantir que os sujeitos satisfaçam suas necessidades, se sintam realizados em seu trabalho e trabalhem motivados. Outra maneira de avaliar os resultados é verificar as adequações realizadas nos papéis para melhor atender as demandas do ambiente.

Apesar do ambiente favorável ao processo de aprendizagem individual aqui identificado, podem-se citar alguns constrangimentos, a própria aproximação entre projetistas e trabalhadores relata um constrangimento: apesar da disponibilidade dos trabalhadores para refletir sobre suas experiências, tais reflexões são enviadas aos projetistas e cabe exclusivamente a eles a decisão sobre a realização de novos processos e/ou atividades. Assim, os trabalhadores não têm autonomia para realizar novas experiências e concluir o ciclo de aprendizagem individual (KOLB, 1984).

Outro constrangimento pode ser relatado: a restrição e preconceitos a respeito de novas experiências. Visto que os trabalhadores apenas têm discricionariedade, ou seja, liberdade para realizar pequenas alterações dentro do processo já definido, experiências que alterem por completo o processo não são bem-vindas. Considerando que, para iniciar o ciclo de aprendizagem, é preciso a disposição do sujeito para vivenciar novas experiências sem preconceitos ou restrições, tem-se aqui um constrangimento.

Apesar de a formação ser realizada a partir das necessidades identificadas pelos sujeitos, a organização da lógica organicista continua com 
sua estrutura projetada previamente e, portanto, com necessidades previamente identificadas por seus projetistas. Portanto, imposições de aprendizagem podem ocorrer durante a realização do trabalho, interferindo no ambiente de aprendizagem de forma negativa. De qualquer forma, seja no processo de aprendizagem definido pelos projetistas ou iniciado pela identificação de necessidades dos próprios trabalhadores, a formação, ocorrendo em "sala de aula" mantém um caráter padronizado, que não respeita o tempo e modo de aprender de cada sujeito, mas preocupa-se em seguir um programa.

Segundo Maggi (2006), a formação na lógica organicista tem uma estrutura para desenvolver as habilidades dos sujeitos para melhor adaptaremse à organização e ao seu ambiente, constituindo-se em uma estimulação para a prospecção, análise e solução de problemas a partir da utilização da experiência já adquirida. Isto é, os trabalhadores devem desenvolver suas habilidades a partir de suas experiências, não havendo o aprimoramento de seus conhecimentos através de novos conceitos e teorias. Esse tipo de estudo mais aprofundado, que envolve conceituação, fica restrito aos projetistas que ainda possuem a atividade de criação e adequação dos processos apesar das contribuições dos trabalhadores.

Nonaka e Takeuchi (1995) ressaltam a necessidade de constante interação entre os sujeitos para que ocorra a aprendizagem organizacional. Tal interação é muito beneficiada no trabalho em grupos ou equipes, no qual os trabalhadores realizam atividades conjuntas e chegam até mesmo a fazer rodízio de tarefas, conforme Motta e Vasconcelos (2006) relatam na lógica organicista.

Essa estrutura de trabalho também possibilita a observação do trabalho dos demais envolvidos, visto que não há barreiras entre os trabalhadores quando todos fazem parte de um grupo de trabalho. Ainda como benefício temse a questão da comunicação, a proximidade entre os trabalhadores permite que eles comuniquem-se livremente, sem necessidade de canais rígidos de comunicação ou existência de interferências, possibilitando uma comunicação 
flexível, adaptável à necessidade dos sujeitos e das situações, possibilitando também a divulgação de conhecimentos tanto tácitos quanto explícitos.

Enfim, o trabalho em grupo também valoriza a reflexão coletiva sobre as experiências, sabendo-se que a comunicação entre os trabalhadores é ampla e existe disponibilidade dos sujeitos para refletirem sobre as experiências vividas, além de proporcionar a realização de atividades amplas e que lidam com imprevistos. Entretanto, identifica-se aqui um constrangimento: apesar dos sujeitos lidarem com imprevistos, não há autonomia para que novos processos e atividades sejam criados a partir das necessidades. Os imprevistos devem ser tratados dentro dos espaços de discricionariedade existentes, definidos pelos projetistas previamente.

Ainda em relação aos imprevistos, pode-se identificar outro constrangimento. Segundo Nonaka e Takeuchi (1995), é preciso que o ambiente proporcione circunstâncias incertas e quebras de rotinas para que seus sujeitos reavaliem seus paradigmas e sejam capazes de inovar a partir daí, criando um novo conhecimento organizacional. Contudo, as organizações da lógica organicista, apesar de admitir variações e adaptações ao ambiente, ainda é projetada previamente visando certo grau de estabilidade e não permitindo alterações em seus processos, a não ser que por decisão de seus projetistas. Assim, são evitadas as quebras de rotina, e os imprevistos que possam ocorrer devem estar contidos nos espaços de discricionariedade permitidos aos trabalhadores, não implicando em mudanças de paradigmas. 


\section{4.) CONCEPÇÃO DE ORGANIZAÇÃO COMO SISTEMA SOCIAL CONSTRUÍDO}

Contrapondo o entendimento das organizações como pré-determinadas aos sujeitos, Maggi (2006) oferece uma alternativa dizendo que as organizações surgem das interações e, portanto, não podem ser descritas previamente, mas apenas compreendidas a posteriori, sendo esta uma abordagem interacionista e fenomenológica.

Tanto a abordagem interacionista quanto a fenomenológica que dão base para a concepção da organização como pós-construída, lidam com a dificuldade de conhecer o mundo real, ao contrário da visão positivista que prega a existência de leis que possibilitam a explicação precisa dos fenômenos. A diferença entre as abordagens está no fato de existir ou não leis naturais e explicações causais: para os interacionistas, essas leis não existem, o mundo é construído pelas interações sociais e, portanto, só é possível conhecê-lo depois destas se realizarem; para os fenomenológicos, nosso conhecimento é restrito ao mundo da aparência, impossibilitando a noção real da essência das coisas, não é possível identificar as tais leis naturais, logo, não se pode afirmar se existem ou não. (CALDERANO, 2007)

O interacionismo e a fenomenologia são abordagens da ciência do espírito (DILTHEY apud MAGGI, 2006), pois lidam com eventos singulares e únicos, nos quais os seres humanos fazem parte integrante e, portanto, só podem adquirir conhecimento através da experiência. Essa ciência existe em contraposição às ciências da natureza, que estudam eventos padronizados e exteriores aos homens, regida por leis naturais e passíveis de explicações através de relações causais, nas quais se enquadra a abordagem positivista.

Maggi assim descreve esta forma de ver a organização: 
Uma concepção da organização como sistema social construído pelas interações dos sujeitos, uma construção cultural que se objetiva e se instrumentaliza. Essa construção não é intencional, a racionalidade dos sujeitos só é reconhecível a posteriori. (MAGGI, 2006, p. 19)

Sendo as organizações passíveis apenas de compreensão a posteriori, não é possível estruturá-las previamente, como no caso da lógica do sistema (mecanicista e organicista), em que os projetistas definem as posições sociais e os papéis que existirão. Deste modo, não existem projetos planejados previamente, os elementos vão se organizando através da institucionalização de valores e hábitos que, paulatinamente, vão tornando-se constrangimentos aos indivíduos, restringindo sua liberdade de ação (MAGGl, 2006).

Ao perceber as organizações como resultados de interações entre sujeitos, pode-se compreender que cada elemento dentro da organização tem poder de decisão sobre suas ações. Ao contrário das interpretações que entendem as organizações como pré-determinadas que, como visto, ou impedem o processo de decisão do sujeito (mecanicista) ou apenas proporcionam discricionariedade (organicista), sendo constantemente constrangedoras ao processo de decisão dos indivíduos.

Na lógica do ator, o constrangimento ao processo de decisão não surge da possibilidade de escolha do sujeito, mas sim das relações de poder com as quais ele lida e que influenciam suas decisões por interferir diretamente em suas conseqüências. Enquanto a lógica mecanicista e organicista restringem as alternativas de escolha do sujeito, a lógica do ator não prevê este tipo de restrição, pois cada sujeito tem autonomia para decidir, entretanto, as conseqüências de suas decisões, como fruto das relações de poder, interferem profundamente no processo por fazer parte de um conjunto de estratégias pessoais.

A lógica dos sistemas pré-concebidos acredita que as relações interpessoais podem ser determinadas previamente, sendo controladas com premiações e punições, enquanto que a lógica do ator entende a organização como o próprio resultado de coalizões, ou seja, formada pelas contínuas interações entre os sujeitos. 
Weick (1973) ainda utiliza como exemplo para a exposição deste pensamento o processo de eleição de uma irmandade, formada por cem pessoas e gerida por um único sujeito. Ele não a criou sozinha, nem poderá governá-la sem o consentimento dos demais membros. São as cem pessoas que a compõem que a gerem, mesmo que de forma indireta e tácita, pois delegam a responsabilidade formal ao seu dirigente eleito.

Por conseguinte, organizações guiadas pela lógica do ator preocupamse com as relações de poder que existem nela, sabendo que as pessoas só obedecem ao que elas próprias querem obedecer. É importante ressaltar que apesar da lógica do ator preocupar-se com as relações inter-pessoais assim como a lógica do sistema/organicista, trata-se de dois enfoques distintos, enquanto esta valoriza o afetivo contido nas estruturas, aquela preza pela questão do poder que cria as estruturas.

Esse pensamento indica a existência de autonomia do ator, mantendo a diferença do conceito de discricionariedade da lógica organicista que, como vimos, apenas flexibiliza a atividade do sujeito, contudo não Ihe dá crédito para criação e mudanças fundamentais. Na lógica do ator, os sujeitos têm autonomia? Atuam conforme suas próprias estratégias e, conforme os jogos de poder existentes criam novos processos dentro da organização e reformulam os existentes, movidos pelas estratégias pessoais, apesar das limitações oriundas das estratégias dos demais sujeitos. Portanto, o mais presente é a heteronomia. A coordenação ideal para uma organização da lógica do ator visa o achatamento completo da hierarquia. Isso porque, quanto mais subordinados um supervisor tiver, menor a proximidade deste com o trabalho daqueles.

A organização trabalha com informações ambíguas, ou seja, incertas e muitas vezes equivocadas, pois dependem do sujeito que as coleta e interpreta. Uma mesma informação pode ser considerada de forma diferente por dois sujeitos e resultar em ações distintas deles, isso é conseqüência do conceito de racionalização utilizado pela lógica do ator que não se refere a um processo consciente prévio à atividade, mas sim a uma justificativa de atos 
passados para torná-los sensatos para o próprio sujeito e para as outras pessoas das quais se sente responsável. (WEICK, 1973)

O ator, sujeito da organização, apresenta comportamento ambíguo igualmente ao ambiente de forma geral, pois apresenta uma diversidade de objetivos pessoais. Segundo Weick (op. cit.), o indivíduo tem necessidade de socialização, ou seja, participar e ser aceito pelo grupo, compartilhando opiniões e atitudes, por outro lado, existe também a necessidade de individualização, a qual faz o ator querer afirmar suas características próprias, diferenciando-se do grupo e ressaltando sua particularidade. Portanto, o comportamento humano perde nesta visão a previsibilidade aceita pelas lógicas mecanicista e organicista, trazendo maior incerteza à estrutura organizacional.

Para trabalhar neste ambiente ambíguo, Weick salienta que é preciso um conjunto de ações cujas inter-relações sejam imperfeitamente concebidas e cujos resultados estejam sujeitos a duas ou mais interpretações plausíveis. Assim, respeitando as relações políticas que dão forma à organização, pretende-se dar o máximo de liberdade aos trabalhadores, sendo cobrado deles a racionalidade a posteriori que explique satisfatoriamente os resultados ao invés de cobrar resultados concretos. Raramente exige-se certeza absoluta nestas organizações. Essa lógica possibilita, portanto, que atividades diversas sejam realizadas apesar da aparente falta de equilíbrio entre elas.

Não se pode, entretanto, falar de projetos de intervenção/mudança no trabalho, visto que nesta lógica a racionalidade dos sujeitos só pode ser conhecida depois de realizada as atividades. Na obra de Weick (1973), vemos que através da interpretação da lógica do ator, nenhuma mudança ocorre de forma planejada e consciente, sendo que a evolução nos processos da organização pode ser comparado ao processo evolutivo animal, que ocorre através de variações casuais e não planejadas, sendo selecionadas pelo ambiente as mudanças que pareçam ser vantajosas ao organismo. As ações, portanto, são mais realizadas por tentativa e erro e menos por planejamentos e estudos detalhados. 
Destarte, têm-se as principais características da lógica do ator: fundamentos na visão interacionista e fenomenológica, acreditando que a organização origina-se das relações entre os sujeitos e não por meio de definições de projetistas. Todos os sujeitos têm a oportunidade de aceitar ou rejeitar ordens e pedidos, respeitando as relações de poder que se instituíram na organização. Para assegurar uma maior liberdade aos sujeitos, mantém-se uma estrutura hierárquica achatada, buscando o ideal de um único supervisor para todos os trabalhadores. Toda atividade é aceitável desde que justificada, mantendo assim a ambigüidade dos processos, visto que não é preciso uma lógica pré-determinada. As mudanças que ocorrem na organização não são resultados de projetos planejados, mas de alterações acidentais que se apresentam como adequadas posteriormente.

A competência, a partir da lógica do ator é entendida como a capacidade de compreender as relações de poder e as conseqüências delas. Trata-se da mesma abordagem ao conceito de racionalização, que é visto como uma forma de analisar o ato após ele ter ocorrido e interpretar suas conseqüências, não havendo uma única resposta correta ou errada já que esta interpretação é mais influenciada pelas características do próprio sujeito que avalia do que pelos fatos concretos e objetivos (MAGGI, 2006).

Segundo Maggi (op. cit.), o desenvolvimento de competências é tido como necessário na lógica do ator para que os sujeitos, além de compreender a situação na qual se encontram, possam tomar consciência dos constrangimentos do sistema que vem sendo estruturado a partir das relações ambíguas e tentar criar oposição a eles.

Os "atores", nesse caso, procuram escapar da adaptação ao sistema; buscam tomar consciência, compreender a construção social, da qual são parte integrante, aprender com a experiência, conquistar, enfim, espaços de poder que Ihes permitam mudar as relações e opor-se de maneira eficaz aos constrangimentos do sistema. (MAGGI, 2006, p. 221)

Para alcançar este desenvolvimento, a formação deve ter caráter introspectivo, ou seja, incentivar os atores a refletirem sobre as relações nas 
quais estão envolvidos e facilitar o processo de compreensão. O autor referido anteriormente mostra em sua obra que este processo de auto-conhecimento deve ter uma orientação não-diretiva, pois cada sujeito analisará suas experiências e seus constrangimentos, sendo mais uma atividade de sensibilização que exposição de conceitos e idéias.

Uma ferramenta muito utilizada na formação concebida segundo a lógica do ator é a reunião de grupo, na qual os participantes podem expor seus sentimentos e emoções, facilitando a compreensão do "eu" dos colegas de trabalho e, logo, facilitando a compreensão das relações inter-pessoais. 0 grupo ainda pode refletir especificamente sobre as relações, sobre as situações que agradaram aos atores e as que causaram desconforto e/ou resultaram em conflitos, sempre utilizando a racionalidade a posteriori.

Maggi (2006, p. 178) resume esta formação nos seguintes objetivos: tornar claros os percursos de institucionalização e tornar os atores conscientes das relações de poder, das zonas de incerteza e dos espaços de liberdade que permanecem para cada sujeito na organização. O resultado é a capacidade do sujeito em opor-se aos constrangimentos do sistema, conseguindo a ampliação de seu espaço de liberdade e mantendo a ambigüidade de suas atividades

Uma das características favoráveis à aprendizagem é o conhecimento do "por que" e do "para quê" aprender que, segundo Dewey (apud KOLB, 1984), é a ação que conecta a aprendizagem aos seus fins desejados, demonstrando a importância do tema aprendido e dando assim início ao processo de aprendizagem. Todavia, o conceito de racionalidade a posteriori adotado pela lógica do ator, não permite compreender os fatos e ações dos sujeitos previamente ou durante sua realização, porém apenas posteriormente, assim, inclusive o processo de aprendizagem não pode ser compreendido previamente, sendo limitado ao resultado de ações não planejadas e nem sempre conscientes.

Portanto, conforme a lógica do ator, o apelo vital da aprendizagem não é apreendido pelos sujeitos para iniciar o ciclo de aprendizagem individual. Além disto, a racionalidade a posteriori inibe o acesso a teorias a respeito das experiências vivenciadas, já que cada experiência é considerada única e não 
podendo ser relacionada com teorias ou outras experiências já realizadas isoladamente.

A reflexão sobre as experiências, ao invés de fazer uso de teorias, voltase à discussão sobre as relações que ocorreram no próprio evento, conforme Maggi (2006) explica, buscando a compreensão das relações interpessoais e das situações que agradaram ou causaram desconforto aos atores. Porém, se, por um lado, este tipo de reflexão constrange a aprendizagem por não associar a experiência com demais conhecimentos, por outro, ela incentiva e possibilita um processo constante de feedback, fator importante para conhecer diferentes pontos de vista sobre a mesma experiência e, assim, incrementar o processo de aprendizagem. De fato, a disponibilidade para reflexão, independente da metodologia utilizada para realizá-la, corresponde a uma característica fundamental do ambiente de trabalho que possibilita 0 processo de aprendizagem individual e que está presente nas organizações da lógica do ator.

É preciso lembrar que as relações de poder e as limitações que elas implicam ao processo decisório são os principais delimitadores do ambiente de trabalho na lógica do ator e, inclusive, o processo de aprendizagem encontrase voltado a eles. A aprendizagem, entendida como uma forma de compreender tais relações para amenizar suas restrições e permitir aos sujeitos maior autonomia, normalmente é realizada em reuniões de grupo, respeitando as necessidades de cada indivíduo e o seu tempo próprio para aprender. Identificamos assim que a aprendizagem individual na lógica do ator não é uma imposição dos superiores e, sim, uma forma de desenvolvimento que o sujeito busca livremente, não havendo programas ou planos de treinamento previamente definidos, como ocorre nas lógicas mecanicistas e organicistas. Conforme as relações de poder são percebidas pelos sujeitos e entendidas como constrangimentos ao próprio trabalho, os grupos iniciam seus debates na busca da compreensão da situação, expressando seus sentimentos e emoções e conhecendo os de seus colegas.

Apesar das diferenças entre os ambientes, um mesmo constrangimento ao processo de aprendizagem individual pode ser identificado nas três lógicas 
descritas até aqui - mecanicista, organicista e do ator - refere-se à autonomia para realizar novas experiências.

Apesar da lógica do ator não ter uma organização previamente definida, mas construída das relações entre seus sujeitos, estes também não têm autonomia para realizar novas experiências justamente pelas imposições surgidas das relações interpessoais. Como visto, as relações de poder que vão ocorrendo no decorrer das atividades de uma organização restringem a liberdade de decisão dos sujeitos e, portanto, novas experiências também são limitadas. As relações de poder ainda implicam em preconceitos pelos próprios sujeitos a respeito de novas experiências, dificultando a realização de experimentos dentro dos espaços de discricionariedade existentes.

A lógica do ator é baseada em princípios fenomenológicos e, justamente por não atuar com questões previamente definidas devido a isso, valoriza as relações de poder nas organizações. Essa valorização implicará em alguns constrangimentos ao processo de aprendizagem organizacional, ao mesmo tempo em que permite parcialmente a criação e disseminação de conhecimento organizacional.

Uma vantagem é a flexibilidade na comunicação, pois os canais não são definidos previamente, eles surgem conforme as necessidades dos sujeitos. Além disso, a interação entre os sujeitos é constante, também devido ao fato de a estrutura não ser definida previamente, mas surgir como resultado das próprias interações entre os atores, possibilitando até a observação do trabalho dos demais envolvidos na organização, importante ao processo de internalização citado por Nonaka e Takeuchi (1995).

Entretanto, como já comentado, as interações resultantes das relações de poder geram constrangimentos ao trabalho dos sujeitos, sendo necessário, inclusive, que a formação nas organizações da lógica do ator voltem-se para a identificação destes constrangimentos (advindos dos jogos de poder) através da expressão de sentimentos e opiniões, buscando melhorar as relações, conforme sugere Crozier (1981). Esses constrangimentos ao trabalho podem inibir os canais de comunicação e dificultar as interações entre os sujeitos, 
tornando-se assim constrangimentos ao próprio processo de aprendizagem organizacional.

Uma situação de constrangimento ao trabalho pelas relações de poder também constrange a reflexão coletiva sobre as experiências, dificultando ou até impossibilitando que os sujeitos expressem suas opiniões a respeito das experiências para criarem e disseminarem novos conhecimentos. Além disso, tal contexto limita a redundância da informação ao constranger a comunicação entre os sujeitos.

Por outro lado, a lógica do ator proporciona determinadas características em seu ambiente de trabalho que favorecem a aprendizagem organizacional, tais como a possibilidade dos sujeitos enfrentarem imprevistos e vivenciarem quebras de rotina. De fato, não se pode falar de rotina em uma estrutura que não admite atividades previamente definidas e estruturadas por completo, o que se pretende aqui ao adotar a palavra "rotina" é descrever a ocorrência de situações muito diferentes das enfrentadas normalmente pelos sujeitos no cotidiano da organização, capaz de causar a mudança de paradigma necessária para a criação de conhecimento organizacional conforme Nonaka e Takeuchi (1995). 


\section{5.) CONCEPÇÃO DE ORGANIZAÇÃO COMO AGIR SOCIAL, COMO PROCESSO DE AÇÕES E DECISÕES}

A terceira via, enfim, propõe alternativas ao enfoque objetivista das ciências da natureza, que foca a organização independente dos sujeitos, e ao enfoque subjetivista das ciências do espírito, que isola o sujeito da organização. Propõe a compreensão do sentido intencional do sujeito frente a um processo de ações e decisões. A idéia de processo implica considerar o tempo como dimensão fundamental: o processo é permanente, jamais terminado, ocorre no nível individual e nas diversas relações organizacionais. Portanto, o processo implica uma "ordem", mas não no sentido de rigidezes, mas no sentido de regulação e estruturação. Assim, a regulação do processo de ações e decisões é a questão central da teoria do agir organizacional: ou seja, busca explicar e compreender como se constitui, se desenvolve e varia o agir regulador do processo de ações e decisões, o que Maggi chama de agir estruturante.

Nesse sentido, e em relação a conceitos e hipóteses que a sustentam, a teoria do agir organizacional exprime uma maneira de ver, de conceber os fenômenos organizacionais. Ela entende a organização enquanto processo de ações e decisões. $O$ agir organizacional tem como característica intrínseca a possibilidade estratégica de produção de ordem, ou seja, de compreensão, construção e reconstrução do processo de regulação. O processo de ações e decisões se auto-organiza.

A teoria do agir organizacional proposta por MAGGI (2006) busca seus fundamentos teóricos e epistemológicos, essencialmente, primeiramente, da obra de Max Weber, em seguida, nas obras de Barnard (1968), Simon (1997), Thompson (1976), Reynaud (1988) e Giddens (1976; 1984).

As contribuições de Max Weber apontam para a construção do idealtipo, resultado da alocação de evidencias e conexões de diferentes características de uma quantidade de fenômenos históricos, difusos e discretos, existentes em diferentes medidas, num quadro conceitual único. $O$ 
agir organizacional é visto como forma de agir social. Webber define o agir social e as formas puras de agir, para então definir o agir organizacional; este caracterizado por uma racionalidade intencional e fundamentada pelo autor como: um agir humano, de um ou mais sujeitos, dotado de sentido intencional que orienta seu curso em referência à atitude de outros sujeitos; concebido como processo de ações; orientado em direção a um objetivo com base no sentido intencional dos sujeitos, seus conhecimentos e atitudes; dirigido para produzir ordem e estudado por uma abordagem que liga a compreensão do sentido da ação com a explicação de causalidade adequada no desenvolvimento do processo.

A teoria do agir organizacional põe em evidencia as razões e modalidades da variabilidade estrutural e organizacional fazendo referência de maneira coerente e explícita a uma abordagem organizacional. Seguindo a via indicada pelas contribuições que constituem seus fundamentos, pode-se dar continuidade a elaboração nos termos próprios de interdisciplinaridade. Fundamenta-se, portanto, na terceira via proposta por Weber, que salienta a compreensão como sentido da ação, a explicação serve para dar conta da dimensão causal, em causalidade adequada, das condições empíricas em ação. Segundo essa abordagem, a avaliação da possibilidade objetiva de relações causais entre as ações ou os eventos individuais ao longo de um processo se apóia sobre a comparação dos processos reais com processos de ação hipotéticos idealmente construídos.

Barnard (1968) e Simon (1997) compartilham da mesma maneira de conceber o agir organizacional, como processo de ação social levando em conta suas características de intencionalidade e racionalidade. Barnard (1968) define o sistema organizacional em termos de "sistema de atividades ou forças pessoais conscientemente coordenadas". A organização se exprime antes de mais nada de maneira informal, e somente em seguida, e em parte, de maneira formal. De modo geral, pode-se dizer que a existência da organização formal se apóia sobre a tendência natural dos indivíduos em cooperar. A teoria do agir organizacional utiliza a obra de Barnard, sobretudo, sua reflexão sobre as relações entre o agir social de um sujeito singular e o agir cooperativo, bem como sua coordenação consciente. 
Thompson (1976) desenvolve o estudo da organização como um processo de ações e decisões orientada por uma racionalidade intencional e limitada, enfrentando a incerteza. A ação organizacional implica relações recíprocas, como qualquer outra relação social, assim, o campo de ação só se torna operacional quando o processo organizacional encontra o ambiente.

As contribuições deixadas por Thompson, apesar de desenvolvidas nos anos 60, mantém-se contemporâneas. A abordagem de Thompson (1976) apresenta os limites e deficiências das interpretações amplamente difundidas pelo funcionalismo sociológico e psicológico, desvelando as reificações da organização e interpretando a variabilidade organizacional. Baliza-se no objetivo de trabalhar as bases conceituais do conhecimento organizacional interpretando seu contexto e sua realidade. O conjunto de organizações passa a ser analisado como processos de ações e decisões orientados para resultados, e não mais como entidades concretas. Redefine-se, portanto, a noção de estrutura, e a posição dos sujeitos no decorrer do processo organizacional.

As características da teoria de Thompson abordam: o agir organizacional, a estrutura, entendida como coordenação do processo de ação, a tecnologia, entendida como conseqüência de escolhas do campo de ação, a explicação da variabilidade organizacional e estrutural, não em termos de determinação e sim de congruências das escolhas de decisão e ação.

Maggi (2006) submete as bases principais de sua teoria a Thompson (1967). De fato, os princípios do agir organizacional seguem os parâmetros definidos por Thompson para o entendimento das organizações. Através de sua discursiva, Thompson redefine a noção de estrutura, identificada como a estruturação do processo de ações e decisões, compreendida como instrumento maior da racionalidade. Ele convida os leitores ao estudo da variabilidade da ação organizacional, ou seja, uma variabilidade que tem sua origem e seu desenvolvimento dentro do processo de ação organizacional e que encontra sua explicação na lógica desse processo. A perspectiva em termos de processo desenvolvida por Thompson leva a apreender os critérios da variabilidade na lógica do agir organizacional. 
A via opcional, que Thompson qualifica de tradição inovadora, ressalta a ação satisfatória ao invés da maximização, a intencionalidade ao perseguir um objetivo ao invés da homeostase, e o processo de ações e decisões ao invés do sistema reificado. Para Thompson, as contingências são variáveis no sentido correto do termo, distintas dos constrangimentos, que são estáveis por um período prolongado. Ambos, o processo organizacional tenta dominar, porém são produzidos pela produção do próprio processo e de seu campo de ação.

O ambiente, neste sentido é escolhido, poder-se-ia dizer, construído, pelo agir organizacional, é o conjunto de outros processos que se revelam importantes no campo da ação escolhido pelo processo envolvido e aceito pelos outros processos. O poder exercido sobre os outros processos é, portanto a recíproca da dependência desses processos, e se exerce através da definição mutável do campo de ação. Para Thompson, o poder de um consenso dirigido a outros processos, aquele que as perspectivas reificantes chamam de poder dirigido ao exterior da organização, não esgota a questão do poder organizacional. Os objetivos organizacionais são definidos como campos de ação futuros que a coalizão dominante concebe. As organizações são tidas como as estruturas de governança das transações, caracterizadas pelo objetivo específico de tender a minimizar seus custos. O agir organizacional se expressa de maneira evidente na coordenação das interdependências, das quais procura reduzir custos trata-se de interdependências de ações técnicas. A transação ocorre quando um bem ou um serviço é transferido através de uma conexão separável do perfil tecnológico.

Em relação ao aspecto fundamental da avaliação organizacional, ela deve estar relacionada à adequação ao futuro, ou seja, as ações a realizar e não as já realizadas, as condições de incerteza do processo de decisão encontram-se no centro dessa avaliação. Trata-se no final de uma avaliação e de um controle das congruências recíprocas das escolhas organizacionais: essa avaliação e esse controle se fundem numa racionalidade intencional e limitada.

A racionalidade intencional e limitada, entendida como a orientação da ação e da decisão que enfrenta a incerteza, compreende todo tipo de 
incertezas, entre as quais aquela devida a informações incorretas. Eis o seu sentido na lógica organizacional.

"Segundo a abordagem de Thompson, é o processo organizacional que produz incerteza, por suas escolhas de objetivos e de percursos para atingi-los, e a incerteza varia no tempo durante o próprio desenrolar do processo." (p.55)

A variação do ambiente, portanto, diz respeito à duração típica dos estados ambientais: suas durações podem ser breves ou longas em relação ao tempo de vida das organizações. As dimensões do ambiente na tipologia de Thompson são por um lado a homogeneidade/heterogeneidade - que corresponde à semelhança/dessemelhança - e, por outro, a estabilidade/mutabilidade no tempo - que corresponde à da duração dos estados ambientais. A incerteza é levada as suas conseqüências extremas em termos de ambigüidade das informações, pelo fato dela não dizer respeito somente aos resultados esperados, mas também aos sujeitos expressando preferências sobre os resultados; não somente aos conhecimentos das relações de causa e efeito, mas também às crenças relativas a esses conhecimentos.

Por tudo o que foi exposto, a teoria de Thompson entende a cultura como a expressão dos valores durante o processo de ação social. Ela é o agir organizacional e a ação organizada. Thompson mantém a distância em relação à visão subjetivista na abertura de seu tratado, explicitando sua própria opção epistemológica.

Reynaud (1988) argumenta que a regulação social resulta de um trabalho longo e complexo, sempre em construção e jamais terminado, em que se entrelaçam conflito, negociação e compromisso. O conflito resulta do confronto de ações que tentam afirmar regras de fonte e natureza diferentes na relação de poder. A regulação resultante dessa dinâmica de troca e de compromisso é denominada regulação conjunta, caracterizada por ser igualmente localizada e provisória.

Giddens (1984) critica as abordagens estruturalistas e funcionalistas defendendo uma concepção dirigida para a compreensão conjunta da estrutura da ação que recusa o imperialismo do sujeito e a totalidade social. Apresenta 
diferentes maneiras de conceituar a estrutura segundo escolhas epistemológicas e ontológicas no que tange a relação entre sujeito humano e sociedade. Para ele, a ação é situada e intencional e os sujeitos observam suas ações, as reações do próximo e suas conseqüências, mesmo sem condições de explicar seus fins. Com relação aos critérios de interpretação de variabilidade estrutural e organizacional, evidenciam-se duas dimensões da ação estruturada, a ação de coordenação das ações técnicas e a ação de coordenação das informações para o desenvolvimento das ações. A teoria da estruturação diz respeito à produção do processo das relações sociais, através do tempo e do espaço, onde a estrutura se revela dual: ela aparece como condição, como constrangimento, mas também como recurso da construção do processo de ação e, em conseqüência, como o resultado da ação humana que a produz. Tal proposição surge em decorrência da insatisfação manifesta e generalizada em relação às perspectivas objetivistas e subjetivistas.

Destaca-se no pensamento de Giddens (1984) alguns traços comuns referentes à estruturação organizacional como: referência à reflexão sociológica sobre as relações sociais, insatisfação ante as perspectivas tradicionalmente difundidas e crença de que a sua chamada teoria da estruturação(TE) aparece como solução para superar os limites dos conflitos entre as perspectivas tradicionais objetivistas e subjetivistas. Alguns teóricos propõem o sincretismo, que sintetizaria as duas abordagens, contudo, integrariam de maneira sincrética teorias antitéticas. Já outra corrente, composta por Wilmott (1981) e Riley (1983), defendem uma abordagem diferenciada denominada de terceira via, sendo então a TE alternativa às abordagens tradicionais, em razão de diferenças epistemológicas e ontológicas, consideraram que a abordagem de Giddens não é compatível com o sincretismo, sendo que a questão crucial não é conectar diferentes teorias, mas diferentes níveis de análise: ação e estrutura.

Maggi (2006) destaca o interesse pela mudança organizacional nas contribuições consideradas, pois compartilham, além disso, a crítica das abordagens tradicionais dessa questão. Ressalta ainda que as abordagens objetivistas tratem as mudanças organizacionais em termos de relações deterministas entre as modificações estruturais e dinâmicas externas, considerando a mudança resultante somente como adaptação passiva. A 
abordagem subjetivista por outro lado, encara a mudança como um fenômeno que escapa a qualquer lógica, considerando que não há nenhuma maneira de conceber a mudança nem de guiá-la.

As divergências entre as duas estão relacionadas à compreensão da mudança organizacional, à posição quanto à intencionalidade da mudança e o tipo de racionalidade subjacente às ações individuais e coletivas e a definição das noções de estrutura e estruturação. Em suma, a teoria da estruturação de Giddens, diz respeito à produção do processo das relações sociais, através do tempo e do espaço, onde se revela uma dualidade na estrutura: como recurso da construção do processo de ação e "conseqüência", como resultado da ação humana que a reproduz. Giddens (1984) critica a falta de atenção dos autores quanto às noções de ação e racionalidade, levando à subestimação do aspecto da intencionalidade relativa à mudança organizacional e a ignorar a conexão entre racionalidade individual e racionalidade organizacional, destacando que esta, tem muita importância na teoria da dualidade da estrutura.

A terceira via é considerada por aqueles que dela compartilham como mais adaptada para se compreender a mudança organizacional do que as concepções dualistas que reificam ação e estrutura e as localizam dentro de uma relação hierárquica. Não são ignoradas as diferenças epistemológicas. Nessa abordagem, a referência a TE é entendida como médium e, ao mesmo tempo, como produto da prática social. Alguns pontos que caracterizam a terceira via abrangem: concepção do sujeito humano como sujeito agente autônomo, concepção da organização em termos de processo e conceito de estrutura como produto de ações intencionais.

Em suma, a teoria do agir organizacional é uma teoria do agir social que abrange os seguintes conceitos e hipóteses: é vista como um processo que não separa sujeito de organização; um local de ações e decisões; onde um processo está relacionado a outros processos, sendo o agir racional que ordena ações em direção ao um objetivo perseguido, um agir intencional e limitado, como é a razão humana; as regras desse processo são formais e informais, explicitas e tácitas, conscientes e não-consistentes, previas e intrínsecas a ação; a estruturação ou regulação do processo de ação concerne a coordenação das ações e do desenvolvimento das ações; a estruturação e o 
processo variam em termos de forma e no tempo. A avaliação do processo de ação concerne a congruência das variabilidades de seus componentes, integrando a congruência em relação ao bem-estar dos sujeitos agentes. Concluindo, a teoria do agir organizacional, segundo Maggi (2006, p.3) permite uma interpretação das mudanças que se produzem no trabalho e nas empresas no que concerne a cooperação, autonomia, flexibilidade, e coordenação, bem como das conseqüências dessas mudanças para os sujeitos envolvidos.

\section{1) Níveis de Decisão e Modos de Regulação: A Autonomia e a Discricionariedade no Processo de Trabalho}

Maggi (2006) ressalta que as disciplinas relacionadas ao trabalho não podem dispensar uma reflexão aprofundada sobre a regulação do processo de ações e decisões, sobre a maneira como ela é produzida, bem como sobre as conseqüências que gera. Os entendimentos de como as decisões autônomas e discricionárias influenciam e são influenciadas pela regulação do processo de trabalho ganham relevância para se entender os processos de aprendizagem.

O processo de ações e decisões emerge do conceito do processo de ação social, e pode ser visto como o desenvolvimento de ações e decisões que afetam o processo concreto e os resultados finais, que por sua vez tem relação com a transformação de materiais, pessoas e processos. Numa abordagem analítica tem relação com a abstração da realidade e intencionalidade. Segundo Maggi (2006, p.128): “Uma regulação está implicada no processo de trabalho, bem como em todo processo de ação social. É intrínseca à idéia de processo que propusemos, entendido como desenvolvimento intencional de ações em direção a um objetivo. Assim o processo não pode ser considerado sem regulação."

O que faz a diferença entre um conjunto de ações e um processo, é que o segundo implica no atendimento de uma ordem, regida por regras. Sendo o agir social intencionalmente orientado, pode-se falar de processo de ação social e de sua regulação. Aborda-se a ordem do processo para indicar sua regulação, sendo esta nunca perfeita e nem completa, tendo como limite a 
conseqüência dos limites da ação e decisões humanas. Quando se fala em regulação, esta pode ser considerada sinônimo de estruturação, a entendendo como "conjunto de regras" e "o desenvolver eficaz para um objetivo". Segundo o autor, outro termo que se pode usar é "estruturação" do processo, sendo que esta é sempre variável, devido aos limites da razão humana, e nunca sendo pré-determinada. Assim, a organização não é vista como ação organizada nem como um conjunto de constrangimentos do processo, mas como agir organizacional, se referindo à ordem do processo. Assim, a estruturação é para nós sempre viável, devido aos limites da razão humana e, portanto da capacidade humana para construir a ordem das ações do processo. (MAGGI, 2006, p.107-136)

A organização entendida na perspectiva do agir organizacional se refere ao entendimento da "ordem" do processo. A regulação torna-se desafiante pois mesmo no consciente pode haver emoção, e o não consciente pode ser encontrado por inteiro no processo racional. Por outro lado, as noções analíticas nos ajudam a compreender que, na descrição da realidade concreta, aparecem misturados aspectos racionais e emocionais. As decisões ocorrem em vários níveis; sendo que o nível superior regula as decisões do nível inferior, como já havia concluído Simon (1997). Observa-se assim, que o processo de decisão não se desenvolve de maneira linear, não se reduz a um único nível. Maggi (2006), enfatiza três fases em relação a decisão, que sofre influência direta dessa regulação: a busca das alternativas após o reconhecimento do problema; a avaliação das alternativas e de suas conseqüências; e enfim a escolha da solução mais satisfatória em relação ao diagnóstico do problema.

Nesse contexto, toda organização, portanto, é ao mesmo tempo autônoma e heterônoma, e essa diversificação atravessa a organização em caráter holístico. A organização passa a ser observada por uma ótica de processos de ações e decisões auto-reguladoras e auto-produtoras, ainda que não concreta não construída e fator determinante do exterior, é inseparável dos sujeitos agentes e decisores. Porém, independente de sua finalidade e construção, a organização apresenta-se como mecanismo constrangedor, ao reduzir a autonomia de decisões dos sujeitos. A autonomia é fator 
representante e ponto de partida para uma valorização efetiva do trabalho humano.

É por essa razão que Maggi fala da ordem do processo para indicar sua regulação, ressaltando que essa ordem nunca deve ser entendida como ordem perfeita, nem completa, nem necessariamente boa; sendo os limites da ordem - da regulação - a conseqüência dos limites da ação e decisão humanas. Em suma, a estruturação é sempre variável - no mesmo processo devido aos limites da razão humana, e das capacidades humanas para construir a ordem das ações no processo. Na linguagem corrente, regrado, estruturado, também quer dizer organizado.

Para Maggi (2006), autonomia significa a capacidade de produzir suas próprias regras e a discricionariedade indica espaços de ações num processo regrado. A autonomia se opõe a heteronomia, que consiste na sujeição do individuo à vontade de terceiros ou de uma coletividade - princípios de regulação, e implica independência. Entretanto, não quer dizer que uma expressão de autonomia num processo de ação implicaria necessariamente uma independência em relação ao processo inteiro. Weber mostrou que em toda regulação do agir social há sempre, ao mesmo tempo, autonomia e heteronomia, sendo que nenhum processo de ação social pode ser completamente autônomo. Por outro lado, nenhum processo de ação social pode ser completamente heterônomo, pelo fato de que sua regulação é o resultado, sempre mutável, de negociação entre todos os sujeitos envolvidos.

Se a autonomia e a heteronomia referem-se à produção de regras, destaca-se que dada esta regra, a discricionariedade indica a possibilidade de escolha de ação alternativa, podendo ser admitida tanto pela autonomia como pela heteronomia. Destaca-se que autonomia e discricionariedade não são a mesma coisa, sendo dois modos de regulação muito diferentes. Esta definição torna-se importante quando se trata de decodificar as mudanças do modelo taylorista/fordista nos processos de trabalho. A delegação é uma transmissão de poder relativo a um campo determinado; sendo este poder concedido ao delegado por parte do delegante. Entretanto, o delegado como todo outro sujeito, pode afirmar sua autonomia. Se ele afirma sua autonomia para um aspecto qualquer de seu campo de ação, essa autonomia poderá ser aceita ou recusada. 
Quando se diz que nenhum processo social pode ser completamente autônomo devido a suas interdependências e que nenhum processo social pode ser completamente heterônomo, lembrando que a regulação seria o resultado de acordos coletivos. Percebe-se então a necessidade de uma "terceira via" que seria o equilíbrio entre as duas situações, é onde entra a discricionariedade, sendo aceita tanto por modelos autônomos quanto heterônomos, proporciona ao indivíduo uma menor rigidez e impõe ou permite uma escolha de soluções mais eficazes. Nesse sentido, parece-nos difícil sustentar a utilização dos termos autonomia e discricionariedade como sinônimos, ou querer reduzir a distinção a um detalhe terminológico. Essa distinção permite uma melhor compreensão da regulação do processo. A discricionariedade é mensurável, no sentido que se pode avaliar qual gama de ação, qual espaço, mais ou menos amplo, é deixado ao sujeito para agir segundo sua discricionariedade.

Por fim, destacam-se dois aspectos. O primeiro, de ordem epistemológica, de que Maggi (2006) segue uma visão diferente, fundamentada no agir organizacional e se distancia daquela que mantém como leitura privilegiada da realidade a descrição do processo concreto, recusando a possibilidade de distinguir seja nas fases de decisão, seja nos diversos níveis do processo de decisão e ação. O segundo, de ordem teórica, refere-se ao lugar da autonomia e da discricionariedade na regulação do processo de trabalho, sendo que ambas se entremeiam e se diferenciam, sendo a diferença entre ambas crucial na compreensão dos modos de regulação. $O$ autor conclui dizendo que a tradição funcionalista e mecanicista, ao pressupor a adaptação do sujeito ao sistema, buscou contrapor autonomia à ordem organizacional, como se fossem mutuamente excludentes. Esclarecendo o papel da discricionariedade presente em todo o processo do agir organizacional, entende-se que "a organização se produz pela produção de sua ordem: só é possível compreender 0 trabalho de organização abordando-o pela estruturação do processo."

O processo se forma, se desenvolve e se modifica por ordem das ações e decisões dos sujeitos, construindo continuamente as regras de sua própria ordem. [...] Pelo próprio fato de participar do processo, o sujeito não pode se manter completamente autônomo. Todavia o 
constrangimento organizacional não pode ser absoluto; é sempre variável e modificável. Cada processo pode, portanto, revelar-se mais ou menos constrangedor para os sujeitos agentes, segundo o grau de autonomia que conseguem expressar na estruturação e desenvolvimento do processo. (MAGGI, 2006; p. 99)

Em linha de raciocínio próxima ao debate imposto por Maggi (2006), Bouyer (2004) apresenta uma reflexão a respeito dos constrangimentos ao trabalho. Bouyer afirma que geralmente, o trabalho é visto como ação, sendo que os sujeitos estariam envolvidos no fazer algo ou não. Enquanto que aquilo que não se pode fazer devido a "constrangimentos" geram fenômenos que demandam investigação. Resultados de pesquisas demonstram o sofrimento gerado nos trabalhadores pela contradição entre os constrangimentos em se realizar um trabalho de qualidade e a exigência de se alcançar altos níveis de produtividade. O autor destaca que o impedimento é a tônica do trabalho humano, sendo que em suas diferentes manifestações pode ser considerado como fonte de sofrimento no trabalho e de doenças ocupacionais. Por isso, a compreensão desse fenômeno requer discussão baseada na organização do trabalho e no conteúdo das tarefas.

Ao considerar o impedimento no cotidiano do trabalho, os contrários tornam-se evidentes. Boyer cita o trabalho em serviços, no qual as relações entre um cliente e um trabalhador são construídas. Neste caso o trabalhador está submetido a pressões contrárias: a empresa, com suas exigências e o cliente com sua demanda, muitas vezes incompatíveis e que geram sofrimento ao trabalhador que precisa decidir entre cumprir as normas e fazer um bom atendimento. Para Bouyer, as causas dos constrangimentos e restrições iniciam-se na elaboração das tarefas, que seguem a lógica da simplificação, separando sujeito e objeto, sem considerar sua complexidade, suas relações. Essa lógica pode levar os trabalhadores até mesmo a restringir a liberdade de seus movimentos, sendo que durante horas eles devem ficar fixos e imobilizados no mesmo local. O projeto da organização do trabalho limita o nível de competência possível para o atendimento ao cliente e obriga o pensamento do trabalhador a se restringir, pelos rígidos procedimentos, apenas àquilo que pode ser feito. A estrutura do trabalho é tão restritiva que 
gera conflitos entre os objetivos de atender bem ao cliente, cumprir as normas e ser si mesmo, um próprio sujeito singular com suas características particulares.

Segundo Bouyer op. cit., o impedimento impõe determinada configuração ao sistema de trabalho, que permanece no agir das pessoas quando o que gerou o impedimento desaparece. Essa configuração que o sistema adquire, e as propriedades que dela emergem, obedece a um conjunto de regras de domínio autônomo, que não possui qualquer traço intencional. A metodologia utilizada por Bouyer para compreender essa configuração, está no campo daquilo que o trabalhador não faz porque é impedido, justificado pela necessidade de se compreender as restrições a que são submetidos os trabalhadores. Métodos de investigação que consideram como as tarefas são elaboradas, resultando em restrições aos trabalhadores são amplamente empregados.

Em conclusão, Bouyer destaca que o impedimento para atingir um objetivo é um mito. Considerando que não existe correlação entre 0 ato de impedir e a eficácia do sistema de trabalho e o impedimento é um efeito que ultrapassa os aspectos intencionais. Compreender o trabalho, na presente abordagem, significa elucidar, além das relações que ele estabelece com a eficácia e com a rigidez dos aspectos normativos, as regras que regem 0 impedimento e seus defeitos.

Para tanto, fala-se em novas formas de organização e também de novos modelos que propõem ou suplantam as seguintes proposições:

- A tarefa taylorista é uma atribuição estável nas ações parcelares e procedimentos de desenvolvimento da ação para sujeitos separados, na base desta concepção da tarefa existe a expropriação do operador e exclusão de sua iniciativa, e como resultado, o isolamento de cada operador e o controle direto de cada execução, a saber, a separação da direção e da execução;

- A autonomia significa a capacidade de produzir suas próprias regras, portanto a capacidade de gerir seus próprios processos de ação, ela implica independência; 
- A discricionariedade indica espaços de ação dentro de um processo regrado, onde o sujeito agente é obrigado a decidir e escolher, num quadro de dependência;

- A autonomia se opõe a heteronomia, no entanto a autonomia e a heteronomia coexistem dentro de todo processo de ação social;

- A cooperação é a ação dirigida ao mesmo objetivo;

- As ações cooperativas podem ser comuns ou separadas. A finalização da ação cooperativa pode ser espontânea ou imposta;

- A cooperação requer uma ordem, uma coordenação;

- A ordem da ação cooperativa (a coordenação) pode ser contextual à ação ou decidida anteriormente;

- A coordenação pode ser contextual a ação (autônoma) ou decidida anteriormente (autônoma e heterônoma);

- A coordenação pode ser por relações recíprocas, com regras de ajuste mútuo; por seqüência, com regras de programa, somente visando o resultado, com regras padrão;

- Os três tipos de coordenação têm entre si, uma relação de inclusividade, e não de exclusividade;

- A ação organizacional é a coordenação decidida anteriormente, é a pré-ordenação autônoma e heterônoma, das ações cooperativas.

Em suma, as principais características da lógica do agir organizacional são a adoção do conceito de racionalidade intencional e limitada, sendo possível compreender e explicar os acontecimentos organizacionais; a possibilidade de contribuição dos sujeitos para a estruturação do trabalho e o processo de decisões, mantendo um equilíbrio entre os momentos de autonomia e de heteronomia através de controles externos (advindos de atividades correlacionadas) e do autocontrole; além da consciência da importância da interdependência entre as atividades e a necessidade de um conhecimento geral da organização e seu ambiente por parte dos sujeitos envolvidos. As mudanças organizacionais não são planejadas por projetistas e nem resultados de ações acidentais que apresentaram uma boa adequação ao 
ambiente, mas sim conseqüência da própria atividade realizada, sendo a análise do trabalho e sua mudança inerente ao próprio trabalho e ao trabalhador.

A formação é caracterizada por um processo constante, presente em cada ação e decisão, podendo ocorrer, portanto, em qualquer situação. Tratase de diferença significativa entre a concepção da formação pelas lógicas anteriores já que é admitido por elas apenas a formação em sala de aula, ou seja, que o aprendizado e o desenvolvimento de competências devem ocorrer fora do período de trabalho, sendo um preparo prévio para as atividades ou um momento reflexivo sobre os acontecimentos.

Sendo a formação parte dos processos da organização, é preciso observar sua fase inicial e terminal para perceber sua conexão com as ações gerais. A fase inicial revela a análise das necessidades de formação enquanto que a final corresponde à análise dos resultados. Por necessidade, Maggi (2006) entende toda competência necessária para a tomada de uma decisão, ocorrendo sua percepção no próprio desenvolvimento da ação. Já os resultados são descritos pelo autor como elementos úteis ou necessários para um grau diferente do processo.

Percebe-se que necessidade e resultado são, na verdade, elementos semelhantes, porém diferenciados pelo ponto de vista do processo: o resultado nada mais é do que a necessidade para outra etapa do processo. A avaliação da formação, então, está diretamente relacionada a satisfação das necessidades que surgem no curso das ações e decisões.

Todos os sujeitos envolvidos projetam e agem na formação, cada qual contribuindo com suas ações e decisões na análise das necessidades e, conseqüentemente, na avaliação dos resultados, além de participarem da planificação e da promoção da formação na organização.

O próprio momento da formação constitui um sistema social: a classe na escola e a classe na formação pós-escolar, mas também as situações de formação não institucionalizadas, não-rotuladas, como são a proximidade do colega do operário na fábrica, do empregado no escritório, do aprendiz na loja do artesão, os primeiros passos do sindicalista na ação sindical. (MAGGI, 2006, p. 171) 
Assim como feito com as demais lógicas, ao comparar o ambiente de trabalho proporcionado pela lógica do agir organizacional e o ambiente necessário para possibilitar o processo de aprendizagem organizacional, podese identificar suas compatibilidades e constrangimentos. No caso da lógica do agir, entretanto, não é possível identificar constrangimentos à aprendizagem, apenas compatibilidades.

A lógica do agir considera as organizações como processos de ação e decisão, sendo a aprendizagem parte do próprio processo. Maggi (2006) explica que a necessidade de aprendizagem é quando, em um processo, percebe-se a necessidade de aprender para poder tomar uma decisão ou realizar uma ação. Assim, não existe imposição da aprendizagem pelos superiores, pois cabe a cada sujeito analisar os processos nos quais está atuando para identificar as necessidades de aprendizagem.

Devido a esta mesma situação de aprendizagem ligada ao processo de trabalho, o tempo e o jeito de cada sujeito aprender são respeitados, visto que o sujeito é o responsável por seu processo de aprendizagem individual para tornar-se apto a trabalhar no processo. Ainda neste contexto, o sujeito sabe claramente o "por que" e "para quê" aprender, pois é o próprio sujeito o responsável por sua aprendizagem.

A concepção das organizações como processos de ações e decisões também permite aos sujeitos a autonomia para realizar experiências, de forma diferente das demais lógicas. Essa autonomia é fundamental para o processo de aprendizagem individual, sendo sua falta retratada em constrangimentos nas demais lógicas por inibir a realização de novas experiências, restringindo e criando preconceitos a respeito.

Com autonomia, os sujeitos ainda podem gerenciar seu tempo, conforme os processos em que estão envolvidos, havendo disponibilidade para a reflexão.

Por fim, deve-se lembrar das relações entre os processos, descritas por Thompson (1976). O autor explica que todos os processos, sejam dentro ou fora das organizações, estão interligados, sendo interdependentes. Essa 
interdependência considerada pela lógica do agir auxilia no processo de aprendizagem individual, pois fomenta a constância dos processos de feedback e ainda valoriza o apoio de pessoas que não participaram diretamente da experiência, ou do processo, aos sujeitos envolvidos.

A lógica do agir organizacional, ao considerar a organização como processos de ação e decisão que não podem ser dissociados dos sujeitos que deles participam, apresenta um ambiente de trabalho em conformidade com 0 ambiente necessário ao processo de aprendizagem individual, como visto. Esta mesma conformidade também é encontrada ao relacionar o ambiente de trabalho proporcionado pela lógica e o necessário ao processo de aprendizagem organizacional. Segundo Nonaka e Takeuchi (1995) têm-se as seguintes características necessárias a aprendizagem: flexibilidade na comunicação, reflexão coletiva sobre as experiências, constante interação entre os sujeitos, entre outras. Tais características estão presentes na perspectiva do agir organizacional.

A visão da organização como processo de ação e decisão, como visto, permite autonomia aos sujeitos atuando dentro de cada processo e mantendo a interdependência com os demais processos existentes dentro e fora da própria organização. Essa autonomia faz com que os sujeitos tomem suas decisões e realizem suas ações da forma mais pertinente possível em relação à situação enfrentada, significando que, inclusive, os canais de comunicação são flexíveis conforme as necessidades do sujeito e do processo.

Além disso, esta estrutura de trabalho compreende a inter-relação entre os processos, permitindo e incentivando a reflexão coletiva sobre as experiências, pois diversos processos podem encontrar-se ligados por elas. Essa relação de constante interação entre os sujeitos ainda facilita a observação do trabalho dos demais envolvidos e, com isso, auxilia nos processos de internalização e socialização que Nonaka e Takeuchi (op. cit.) citam como parte da aprendizagem organizacional.

A vivência de circunstâncias incertas e quebras de rotina são fundamentais para a criação de conhecimento organizacional, pois auxilia na quebra de velhos paradigmas e na idealização de novos. A lógica do agir, ao 
permitir autonomia aos sujeitos, permite também que eles vivenciem as mais diversas experiências e atuem frente a elas sem maiores restrições, favorecendo fortemente o processo de aprendizagem organizacional.

É preciso dizer que este processo ainda é favorecido pelo fato de o processo de aprendizagem individual não sofrer constrangimentos no trabalho na lógica do agir. Toda aprendizagem tem seu início a nível individual e, posteriormente, é compartilhada com os demais sujeitos, tornando-se aprendizagem organizacional, portanto, ter de fato todos os sujeitos em processo de aprendizagem individual é o primeiro passo para um processo otimizado de aprendizagem organizacional. 


\section{6.) APRENDIZAGEM NAS ORGANIZAÇÕES}

$\mathrm{Na}$ busca da origem dos estudos sobre aprendizagem nas organizações, observa-se que os trabalhos que a discutem surgiram como um desdobramento da teoria comportamental da firma de Cyert e March (1963) e enfocavam os níveis estratégicos das organizações. Discutiam basicamente questões relacionadas aos ajustes organização-ambiente face às mudanças externas. Daí em diante, as pesquisas realizadas giravam em torno de temas tais como inércia organizacional, a formação e convergência de receitas industriais, processos de desaprendizagem e teorias de ação, dentre outros. A aprendizagem organizacional, não necessariamente assim denominada na literatura pesquisada, concernia capacidade da organização de vincular seu sucesso à formulação e reorientação de estratégias adaptadas ao meio. Destacam-se autores como Burns e Stalker (1961) com "The Management of Innovation" e Lawrence e Lorsch (1972) com "O Desenvolvimento da Organização".

No final da década de setenta, depois de um período ausente do debate da teoria das organizações, o tema aprendizagem organizacional reaparece gradativamente como área de estudo. Destacam-se March e Simon (1981), Argyris e Schön (1974) e Duncan e Weiss (1979). Tentaram levar a discussão para o nível operacional, tratando de questões relacionadas à aprendizagem contínua, em grupos e outros temas genericamente associados aos programas de qualidade total.

A partir da década de 1990, especialmente com a obra de Senge (1990), a aprendizagem organizacional deixa de ser "pano de fundo" para ocupar posição central nos estudos organizacionais, tanto no campo prático quanto no teórico (MINER e MEZIAS, 1996). Novamente o foco é o nível estratégico, contudo também preocupado com as conexões entre os diferentes níveis organizacionais com os processos de aprendizagem organizacional, competências e estratégias. Como afirma Mintzberg (2006), aprendizagem 
organizacional é o processo de aquisição de conhecimento, distribuição de informações, interpretação de informações e manutenção organizacional na adaptação bem sucedida às circunstâncias de mudança. Ou seja, a aprendizagem envolve o ajuste das ações da organização, com base em sua experiência e na de outros.

Além disso, a aprendizagem organizacional passa a ser associada, na ampla e diversificada literatura emergente, aos assuntos inovação e conhecimento. Em relação à gestão do conhecimento, ela é associada não apenas à aquisição do conhecimento externo, mas também à aquisição do conhecimento interno, bem como a interação entre externo/interno. Além da preocupação com a criação de conhecimento, também existem estudos envolvendo a descoberta do conhecimento, que tornam explícitos saberes tácitos.

Em suma, em uma perspectiva ampla a aprendizagem organizacional não é algo novo. Contudo, sua consolidação como campo de pesquisa teóricoprático e linha de ação estratégica deu-se no período que vai do final da década de 1980 até o início da década de 1990 e se estende até os dias atuais. É exatamente neste período que diversos autores como De Geus (1988); Stata (1989) e Nonaka e Takeuchi (1995), apontam-na como uma "tecnologia" ou estratégia capaz de conceder às organizações um diferencial competitivo.

Apesar da difusão de estudos sobre aprendizagem nas organizações, a pesquisa bibliográfica demonstra que não há consenso em relação ao conceito de aprendizagem organizacional em si ou em relação a um modelo ou teoria específica que possa operacionalizá-lo. Segundo Fiol e Lyles (1985, p. 803), a imprecisão em relação a este conceito remonta à definição feita por Simon no final da década de 1960 em que, por um lado, a aprendizagem é equacionada com o desenvolvimento de insights, ou seja, com mudança em estados de conhecimento que não é claramente perceptível e, por outro lado, a aprendizagem é equacionada com resultados estruturais e de outras ações, ou seja, com mudança mais facilmente visível. A distinção entre estes dois tipos de mudança, que normalmente não ocorrem ao mesmo tempo, é essencial; 
entretanto, ela não tem ocorrido. Kolb (1984) corrobora ao afirmar que não existe conhecimento proveniente das experiências e sabedoria de um único sujeito, mas sim aprendizado adquirido por meio dos conhecimentos já existentes na sociedade.

A literatura sobre o tema também explicita o esforço de explicar basicamente como as pessoas aprendem. As várias teorias de aprendizagem existentes não oferecem uma resposta universalmente aceita. Um ponto central de controvérsia tem sido o dilema entre os enfoques abstratos (teorias cognitivas) e concretos (teorias de aprendizagem comportamentais). Contudo, percebe-se também uma considerável tendência na ciência social moderna em reconhecer tanto as cognições como as contingências ambientais no processo de compreender e explicar a aprendizagem de forma mais completa.

De acordo com Fleury e Fleury (1997, p. 20), "de forma geral, a aprendizagem organizacional incorpora, sem, todavia polarizar, este debate entre os modelos behaviorista e cognitivista, no que diz respeito ao fato do processo de aprendizagem implicar ou não mudanças comportamentais visíveis, mensuráveis." De fato, continuam os autores, "o processo de aprendizagem em uma organização não só envolve a elaboração de novos mapas cognitivos, que possibilitem compreender melhor o que está ocorrendo em seu ambiente externo e interno, como também a definição de novos comportamentos, que comprovam a efetividade do aprendizado". Esta posição demonstra o que a literatura trabalha separadamente, na maior parte dos casos, tem-se a montante um mapa cognitivo, que se aproxima do conceito de racionalidade limitada de Simon, e à jusante comportamentos que demonstram o aprendizado adquirido.

É importante distinguir entre cognição e comportamento, pois não apenas representam fenômenos diversos, mas também não necessariamente constituem um mútuo reflexo exato. Além disso, a ocorrência de um não implica a ocorrência do outro. Podem acontecer mudanças comportamentais sem que haja qualquer desenvolvimento de associação cognitiva. Pode também haver ganho de conhecimento sem qualquer mudança comportamental. Contudo, de acordo com Kolasa (1978, p.163), "A 
aprendizagem é a modificação do comportamento como resultado de alguma experiência". Argyris e Schon (apud Kim, 1998, p.63) afirmam que a aprendizagem só acontece quando novos conteúdos são traduzidos em diferentes comportamentos que sejam reaplicáveis. Portanto, conclui-se que um aprendizado coerente exige a confluência de mudanças cognitivas e comportamentais.

Independentemente da abordagem adotada, a ênfase tem sido a reflexão sobre como as pessoas aprendem, ou ainda quais as principais barreiras à aprendizagem. No presente estudo, usando o linguajar proposto por Maggi (2006), enfocar-se-á as questões relativas às barreiras a aprendizagem, que ele trata de constrangimentos.

Percebe-se que aprendizagem está intimamente ligada com o conceito de conhecimento, sobre a sua natureza e suas possíveis fontes. Nonaka e Takeuchi (1995) explicam que alguns pensadores, como Platão e Descartes, consideram a concepção de conhecimento como um processo racional, adquirido somente via reflexão, o que implica em uma aprendizagem extremamente reflexiva. Já outros pensadores, incluindo Aristóteles e Locke, acreditam na sua concepção como processo empírico, adquirido por meio das experiências vividas, indicando a aprendizagem como um processo possível unicamente através da experimentação. O que novamente evidencia a dicotomia mapa cognitivo e comportamentos.

Nonaka e Takeuchi (op. cit.) descrevem em sua obra o histórico deste impasse para chegarem à conclusão de que conhecimento é proveniente da reflexão e da experiência concomitantes, portanto, a consistência do aprendido depende de ambos. Essa concepção preza a união entre homem e natureza, corpo e mente, individual e coletivo, não fazendo separação entre sujeito e objeto, situação ideal à aprendizagem. A adoção deste conceito também é observada na definição de aprendizagem de Kolb (1984), que a define como um processo dialético entre opostos: concreto/abstrato, observação/ação, tornando possível o conhecimento na íntegra, ou seja, de forma racional e empírica. 
Como visto, a criação do conhecimento depende do processo de aprendizagem individual, para que a organização faça uso deste conhecimento é preciso que haja um processo de aprendizagem organizacional, onde as pessoas compartilhem seus aprendizados e tornem-se aptas a inovar em seus trabalhos. Contudo, neste ajuste, as organizações dependem de seu potencial de aprender, reaprender, ou desaprender a partir de experiências passadas.

Dodgson (1993, p, 385) enfatiza a relevância da capacidade de desaprender para as organizações à medida que os conhecimentos retidos ou os padrões de comportamento adotados tornam-se obsoletos, redundantes, ou inadequados. A atividade de descartar é tão importante quanto a de adquirir novos conhecimentos. Hedberg $(1981$, p.3) salienta que dado o ritmo das mudanças, a lentidão em desaprender pode constituir uma fraqueza crítica.

Argyris (1997) ressalta que embora se perceba e se reconheça a aprendizagem organizacional como um processo fundamental para 0 desenvolvimento organizacional, ainda persiste um pensamento quase unânime em relação ao modelo de aprendizagem praticado pelas empresas, qual seja o modelo Single Loop, ou aprendizado em circuito único (direcionado para a manutenção do conhecimento). Existe, todavia, de acordo com Argyris, um segundo modelo muito mais alinhado às necessidades atuais - o Double Loop, ou aprendizado em circuito duplo (questiona o que aprende e revisa princípios) - que preenche muitas lacunas de organizações que buscam o dinamismo. As características de tais modelos podem ser vistas no quadro 1. 
Quadro 1 - Os modelos de ação

\begin{tabular}{|c|c|c|}
\hline & Single Loop & Double Loop \\
\hline 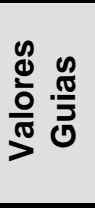 & $\begin{array}{l}\text { Ter controle unilateral das situações } \\
\text { Vencer, não perder } \\
\text { Suprimir os sentimentos negativos } \\
\text { Enfatizar a racionalidade }\end{array}$ & $\begin{array}{l}\text { Utilizar informações válidas } \\
\text { Dar às pessoas liberdade de escolha com } \\
\text { base em informações válidas } \\
\text { Assumir responsabilidade pessoal } \\
\text { (comprometimento) }\end{array}$ \\
\hline 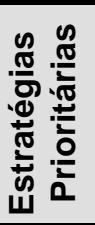 & $\begin{array}{l}\text { Controlar o ambiente e as ações } \\
\text { unilateralmente } \\
\text { Auto-controle e controle dos outros } \\
\text { de forma unilateral }\end{array}$ & $\begin{array}{l}\text { Controle compartilhado das situações } \\
\text { Participação no desenho e implementação } \\
\text { das ações }\end{array}$ \\
\hline 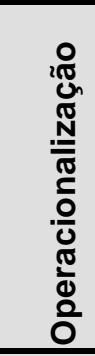 & $\begin{array}{l}\text { Atribuições e avaliações subjetivas } \\
\text { Oferta de cursos que desencorajam } \\
\text { questionamentos } \\
\text { Proporcionar visões óbvias do que é } \\
\text { correto } \\
\text { "Maquear" atribuições e avaliações } \\
\text { Fazer a mudança parecer algo que } \\
\text { prejudica o status quo. }\end{array}$ & $\begin{array}{l}\text { Atribuições e avaliações fundamentadas } \\
\text { em dados relativamente objetivos } \\
\text { Encorajar a discussão de conflitos em } \\
\text { pontos de vista } \\
\text { Encorajar o teste público das avaliações }\end{array}$ \\
\hline 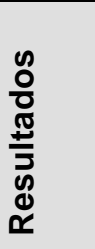 & $\begin{array}{l}\text { Relacionamentos defensivos } \\
\text { Baixa liberdade de escolha } \\
\text { Reduzida produção de informações } \\
\text { válidas } \\
\text { Reduzidos testes públicos das idéias }\end{array}$ & $\begin{array}{l}\text { Há uma redução gradual e constante dos } \\
\text { relacionamentos defensivos } \\
\text { Aumento das informações válidas } \\
\text { contextualmente pela liberdade de } \\
\text { escolha. }\end{array}$ \\
\hline
\end{tabular}

Fonte: Argyris, Putnam \& McLain Smith (1985, p. 89); Anderson 1997.

Observando o quadro 1, é possível perceber que o modelo mais adequado ao desenvolvimento das propostas do agir seria o double-loop; contudo, para que haja nas organizações a mudança para o referido modelo, algumas ações deveriam ser seguidas. Segundo Argyris, op. cit., antes de se implementar as referidas ações em níveis hierárquicos inferiores, a cúpula já deverá estar praticando-as há algum tempo. Resumidamente, destacam-se duas ações:

- Proporcionar conscientização de que na empresa há preponderância do modelo single-loop;

- Ajudar as pessoas a perceberem e relacionarem os efeitos na ação organizacional da inconsciência habilidosa (indivíduos que são incapazes de descrever a fonte de suas habilidades) e da 
incompetência habilidosa (indivíduos que incorrem em erros em função da tentativa de autopreservação e previsões determinísticas) e fazer com que exercitem, na prática, estas novas percepções e relações.

Não seriam estes, constrangimentos a aprendizagem? Para que a mudança no modelo de ação tenha sua chance de eficácia aumentada, a organização deve primar por e desenvolver indivíduos que: não temam dizer totalmente o que pensam; valorizem e busquem, primeiramente, entregar suas contribuições para um todo (equipes, célula, organização...) e estejam em busca do conhecimento válido e útil para a criação de soluções. (ARGYRIS, 1997). Ações permitidas por organizações que se pautam pelas propostas do agir organizacional.

\section{1) Aprendizagem Individual e Aprendizagem Organizacional}

Embora, de forma geral, a literatura indique que os indivíduos sejam a entidade primária de aprendizagem, criando estruturas que possibilitam a aprendizagem alavancadora da transformação organizacional, a aprendizagem organizacional é mais do que a soma das aprendizagens dos indivíduos (DODGSON, 1993, p.377; DUNCAN e WEISS, 1979, p.88). Weick e Westley (1996, p. 441-2), apontam que embora os processos de aprendizagem social possam ser mais bem compreendidos pela análise dos processos de aprendizagem individual e vice-versa aprendizagem organizacional não é o mesmo que aprendizagem individual em um contexto organizacional como parecem indicar autores como Argyris e Schön (1974).

Como expõem Fiol e Lyles (1985, p.805), grande parte da literatura de aprendizagem individual não se aplica diretamente a aprendizagem organizacional, especialmente em nível estratégico e em situações nãorotineiras. É fato, porém, que assim como os indivíduos, as organizações possuem sistemas cognitivos e memórias. Fato corroborado por Fleury e 
Oliveira (2002), onde explicam que as organizações, apesar de não terem cérebros, possuem sistemas cognitivos e memórias que resultam em rotinas e procedimentos relativamente padronizados para lidar com problemas internos e externos. Inovações nestas rotinas e procedimentos indicam a criação de novos conhecimentos institucionais provenientes da aprendizagem organizacional.

Portanto, elas desenvolvem e mantêm padrões de aprendizagem que não apenas influenciam os seus membros imediatos, como, por vezes, acontece com os indivíduos, mas que são continuamente transmitidos aos demais membros através de histórias, normas, e rotinas (MITROFF e KILMANN, 1976; MARTIN, 1982); enfim, pode-se dizer que a aprendizagem organizacional está institucionalizada. Ampliando, fundamentando-se em Maggi (2006), a institucionalização do aprendizado, ou das formas de aprender, se dá pelo caminho ditado pelo modelo de gestão (concepção de organização) vigente, que privilegiará x ou y formação, bem como as validará como menos ou mais valiosas.

Desta monta, a aprendizagem individual é limitada pela capacidade do indivíduo de interpretar realidades complexas, a clássica racionalidade limitada de Simon (1997), além de ela ser socialmente construída, determinada pelas condições do meio (processos institucionalizados), que também tem sua "racionalidade" limitada. Desta forma, embora a aprendizagem organizacional seja um processo interno, no contexto da organização, ela estará delimitada pelo corpo de conhecimento e pelo tipo de informação disponível, aceito ou tido como verdadeiro, e compartilhado pelos demais membros da organização dentro de seus espaços discricionários.

Conseqüentemente, mais do que socialmente construída, a aprendizagem tende a ter características específicas fortemente vinculadas à cultura organizacional. Portanto, se não compreendidos e revisados os processos, a aprendizagem ficará restrita aos padrões internos (racionalidades) que corroborarão paradigmas pouco confiáveis do ponto de vista das novas exigências competitivas (DODGSON, 1993, p.385; MAGGI, 2006). Na visão de Argyris (1985), o problema principal é que poucas pessoas têm consciência de 
que os mapas que elas utilizam para guiar suas ações não correspondem às teorias que elas explicitamente adotam e que ainda menos pessoas têm consciência dos mapas ou teorias que na realidade utilizam. Kim (1998, p.64) expõe que é importante compreender duas partes da definição de aprendizagem: o que as pessoas aprendem (Knowhow) e como compreendem e aplicam o que aprendem (Know-why). A partir daí, Kim define aprendizagem individual como o "aumento da capacidade de alguém tomar ações eficazes".

Nesse sentido, Maggi (2006) propõe um novo tipo de estrutura, consensualmente aceita pelos membros da organização, composta de conceitos que agrupam fenômenos em categorias, tornando, assim, possível o pensamento abstrato. O que Maggi propõe com o agir organizacional é maior do que o conceito de construção social da realidade, sua abordagem incorpora, também, a definição da própria organização e dos seus processos internos. Já que as estruturas paradigmáticas existentes nas organizações fornecem um modo de perceber e interpretar o mundo sobre o qual os membros da organização aprendem, para ser capaz de se comunicar eficazmente e compreender as ações dos outros e as expectativas de comportamento que a organização tem dele, o indivíduo deve aprender os sistemas de conceitos da organização. Principalmente por meio da socialização, que permitirá os indivíduos adquirirem entendimento sobre as instituições do aprendizado. As abstrações generalizadas das relações de ação-resultado fornecem meios de determinar a importância das perguntas e respostas no processo de aprendizagem.

Percebe-se que a discussão proposta por Maggi (2006) de que a concepção organizacional sobre sua estrutura influencia diretamente nas formas de conceber a formação consolida-se na literatura. Pois se os indivíduos são ao mesmo tempo sujeitos e objetos da aprendizagem no sentido que criam e reforçam e são por esta criados e reforçados, cultura, estratégia, estrutura e ambiente são temas intimamente ligados com o tema aprendizagem organizacional. Este é um ponto de consenso na literatura. Para que direcionem positivamente a aprendizagem da organização, estes elementos 
devem ter características próprias à aprendizagem, tais como flexibilidade e adaptabilidade.

A instituição não apenas prediz as ações tomadas, mas também influencia o desenvolvimento cognitivo e comportamental da organização. Tanto a mudança, quanto a aprendizagem organizacional freqüentemente envolvem uma reestruturação do sistema de normas e crenças. Ao delimitar os limites do processo decisório e um contexto para a percepção do ambiente, a estratégia influe ncia a aprendizagem. A postura estratégica da organização cria um momento, um ímpeto para a aprendizagem que tende a ser resistente a pequenos ajustes, requerendo, portanto, grandes reorientações e ampla revolução para que a orientação estratégica possa ser mudada.

A estrutura pode desempenhar um papel crucial na determinação dos processos da aprendizagem. $O$ projeto organizacional voltado para a aprendizagem, para a ação e decisão críticas requer o distanciamento das estruturas mecanicistas (FIOL e LYLES, 1985, p. 804-5). Segundo Argyris (1994), o grande distanciamento inconsciente entre os significados criados e aqueles realmente implementados, ou seja, entre os valores e padrões teoricamente adotados (teoria assumida) e aqueles realmente válidos na implementação rotineira de ações (teoria aplicada) é constrangimento crítico da aprendizagem organizacional, além de causa significativa da emergência da estratégia de resistência defensiva ampla e inconscientemente difundida e perpetuada nas organizações.

Nonaka e Takeuchi (1995) descrevem o processo de aprendizagem organizacional a partir da classificação do conhecimento em tácito e explícito. Segundo os autores, a criação de conhecimento organizacional depende essencialmente da interação dinâmica e contínua entre estes dois tipos de conhecimento dentro de um grupo de pessoas, que pode ocorrer através de quatro processos distintos: socialização (conhecimento tácito de um sujeito torna-se conhecimento tácito de outro sujeito), externalização (conhecimento tácito torna-se explícito para outro sujeito), combinação (conhecimento explícito compartilhado) e internalização (conhecimento explícito torna-se tácito para outro sujeito), como mostra o quadro 2. 
Quadro 2 - Quatro modos de conversão do conhecimento

\begin{tabular}{|c|c|c|}
\hline \multicolumn{1}{|l|}{ PE } & $\begin{array}{c}\text { CONHECIMENTO } \\
\text { TÁCITO }\end{array}$ & $\begin{array}{c}\text { CONHECIMENTO } \\
\text { EXPLÍCITO }\end{array}$ \\
\hline \hline $\begin{array}{c}\text { CONHECIMENTO } \\
\text { TÁCITO }\end{array}$ & SOCIALIZAÇÃO & INTERNALIZAÇÃO \\
\hline $\begin{array}{c}\text { CONHECIMENTO } \\
\text { EXPLÍCITO }\end{array}$ & EXTERNALIZAÇÃO & COMBINAÇÃO \\
\hline \multicolumn{2}{|c|}{ FONTE: ADAPTADO DE NONAKA; TAKEUCHI (1995, P.62) } \\
\hline
\end{tabular}

Por conhecimento explícito entende-se todo conhecimento formal e sistemático, que pode ser expresso em palavras e em números, um exemplo desta categoria são as fórmulas químicas e as regras de modo geral. Quanto ao conhecimento tácito, este compreende todo conhecimento não visível ou comunicável, é individual, subjetivo, intuitivo e baseado nas experiências do próprio indivíduo, em seus ideais, valores e emoções (NONAKA e TAKEUCHI, 1995).

A criação do conhecimento, tanto explícitos quanto tácitos, originase na aprendizagem individual. É através da disseminação destes conhecimentos entre os demais sujeitos da organização que leva a aprendizagem organizacional. Conforme Nonaka e Takeuchi (1995), a criação do conhecimento institucional dá-se primordialmente pela transformação dos conhecimentos tácitos em explícitos, pois é neste momento que o aprendizado individual conquistado com as experiências pessoais pode ser compartilhado de forma abrangente com os demais. Kolb (1978, p.38-39) expõe que aprendizagem é o processo em que o conhecimento é criado, através da transformação da experiência. $O$ processo desta transformação, a externalização, caracteriza-se por embasar-se no diálogo e na reflexão coletiva, fazendo uso de metáforas e analogias para facilitar a transposição do abstrato e subjetivo, tornando possível explicar situações e ações que até então não eram percebidas ou eram apenas sentidas. 
Apenas a externalização não é suficiente para que as organizações aprendam e inovem em seus procedimentos, os outros três tipos de transformação do conhecimento também têm sua relevância por serem meios de disseminação do conhecimento pela organização. A partir do momento que um conhecimento tácito explicita-se, pela externalização, transforma-se em novos conceitos e procedimentos que precisam tornar-se parte do cotidiano dos trabalhadores, ou seja, criar novos conhecimentos tácitos, através da internalização. É neste processo que os sujeitos vivenciam novas experiências, sendo caracterizado por Nonaka e Takeuchi (1995) como learning by doing, isto é, aprender fazendo. Isso implica em experimentação, situações práticas e reais, utilizando o conhecimento já existente e externalizado por outros indivíduos.

Outro modo de conversão do conhecimento é a socialização, descrita pelos autores como um processo de compartilhar experiências para tornar 0 conhecimento tácito de um sujeito em conhecimento tácito de outros, não sendo preciso usar linguagem, bastando apenas a observação, imitação e prática. Este processo é importante por ser uma fonte de conhecimento tácito que, posteriormente, poderá ser exteriorizada, resultando em inovações.

Por fim, há o processo de combinação que, assim como o de externalização, resulta em disseminação de conhecimento explícito, sistematizando conceitos e esclarecendo procedimentos. Esse processo pode ocorrer via registro e leitura de documentos, conversas, e-mails e demais formas de comunicação. É a combinação que assegura que todos os colaboradores da organização conheçam as normas e processos já estipulados, fortalecendo a memória organizacional citada por Fleury e Oliveira (2002) e, assim, perpetuando o conhecimento criado através do tempo.

Esses diversos processos ocorrem através da interação entre os sujeitos das organizações, envolvendo todos os colaboradores e, inclusive, pessoas que trabalhem em outros ambientes organizacionais, como clientes, fornecedores e concorrentes. Não é possível limitar essa interação, pois demonstra $o$ fato que a aprendizagem organizacional depende da 
aprendizagem individual e não somente das ações de especialistas e projetistas (NONAKA; TAKEUCHI, 1995).

Nonaka e Takeuchi (op. cit.) ressaltam que para os processos de transformação do conhecimento ocorrer nas organizações são requeridas algumas condições. Primeiramente, a organização deve ter intenção de propiciar o ambiente requerido, mantendo uma estratégia de criação de conhecimento coerente com suas metas e objetivos gerais. Dutra (2004, p. 20) relaciona esta intenção com a cultura organizacional e explica a importância da relação adequada entre trabalhador e empresa:

(...) A existência dessa cultura [de aprendizagem] depende dos vínculos estabelecidos entre as pessoas e a organização. As culturas centradas no comprometimento mútuo, entre pessoas e organização, na gestão participativa e na busca de renovação contínua terão mais chances de sucesso por estarem alinhadas com os valores que vêm sendo consolidados em nossa sociedade.

Portanto, para que ocorra aprendizagem organizacional é preciso envolvimento dos colaboradores da organização, obtido através da possibilidade deles participarem do processo de decisão e de realização de novos projetos conforme suas perspectivas. Isso significa que os sujeitos devem ter autonomia para agir, não ficando restritos a funções rotineiras. A participação em diversos projetos também permite que os sujeitos lidem com situações adversas, circunstâncias incertas e quebras de rotinas, que levam os sujeitos a reavaliarem seus conceitos e questionar os eventos, resultando em mudanças de paradigmas. Nonaka e Takeuchi (1995) classificam de caos criativo essa situação que induz à inovação devido ao novo contexto em que se trabalha. Pode-se ainda definir como condição básica para o processo de aprendizagem organizacional a redundância de informação. Visto que o processo depende grandemente da interação entre os sujeitos e das trocas de informações que ocorrem entre eles.

Nonaka e Takeuchi (1995) explicam que é necessário que haja uma comunicação intensa entre os membros da organização, daí o termo redundância de informações para realmente destacar a relevância do fácil acesso à informação dentro de uma organização. Isso significa que todos devem compartilhar informações com todos, mesmo com indivíduos que não 
precisem dela em um primeiro momento, pois é provável que as informações sejam utilizadas em algum momento no decorrer do processo por motivos diversos.

\section{2) A Integração da Aprendizagem Individual e Organizacional}

Almejando aprofundar o entendimento do processo de integração da aprendizagem individual e aprendizagem organizacional discutir-se-á, a partir da proposta unificadora de Kim (1998) os passos necessários para que a aprendizagem ocorra de forma sistêmica na organização.

Lewin (apud KOLB, 1997) concebe a aprendizagem individual como um ciclo quadrifásico, onde a experiência concreta é a base da observação e da reflexão. As observações são assimiladas e formam uma teoria a partir da qual pode-se deduzir o surgimento de novas implicações (conceitos) para a ação. Essas implicações guiarão a ação (teste de conceitos), criando novas experiências. Adaptando este modelo, Kofman (apud Kim, 1998) criou o modelo OADI (sigla em inglês de: observe-appraise-design-implement). Este modelo preserva as características do modelo de Lewin, mas, quando aplicado em um contexto organizacional, apresenta conexões mais claras com as atividades. A representação deste modelo pode ser observada na figura 2.

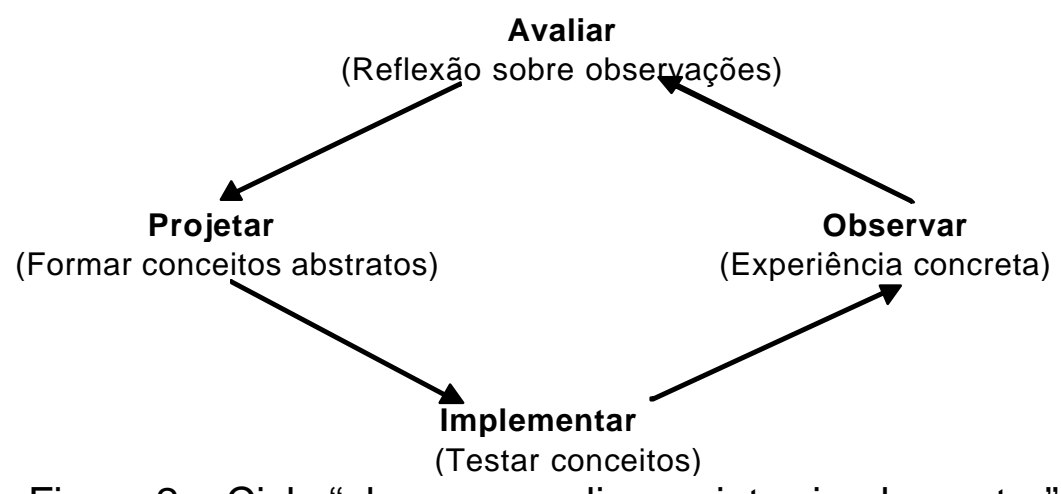

Figura 2 - Ciclo "observar-avaliar-projetar-implementar" (OADI') Fonte: Adaptação de F. Kofman, por Kim, 1998, p. 61-92.

\footnotetext{
${ }^{1}$ As siglas vem do inglês aprraise, observe, implement e design.
} 
Kim (1998) afirma que existem dois tipos de aprendizagem: a operacional, que representa a aprendizagem de todas as etapas para se completar uma tarefa específica, ou seja, aprendizagem em nível de procedimentos; e a conceitual, que diz respeito a pensar porque as coisas são feitas, desafiando muitas vezes a própria natureza ou existência de condições, procedimentos ou concepções predominantes.

Por não levar em consideração o papel dos modelos mentais, Kim (1998) considera incompleto o ciclo de aprendizagem OADI (visto anteriormente), no sentido deste ser uma ferramenta para se compreender melhor como a aprendizagem individual influencia a aprendizagem organizacional. Visando esclarecer esta questão, o autor acrescentou o papel da memória (modelos mentais) ao ciclo OADI, como mostra a figura 3.

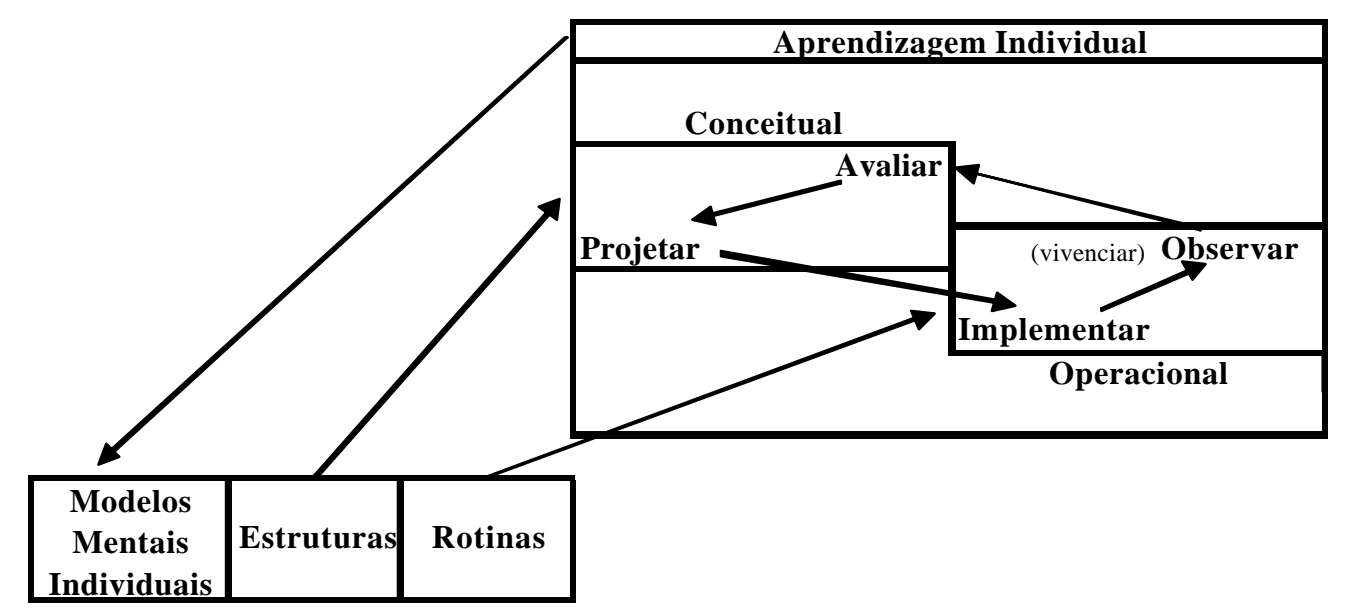

Figura 3 - Modelo simples da aprendizagem individual: Ciclo OADI de modelos mentais individuais

Fonte: Adaptado de KIM (1998, p.61-92)

Observa-se uma sensível diferença neste modelo em relação ao apresentado na figura 2, que foi uma adaptação do modelo utilizado por Kofman. Kim (1998, pág.67), considera projetar e avaliar como componentes da aprendizagem conceitual, e implementar e observar (vivenciar) como componentes da aprendizagem operacional.

Visivelmente, uma empresa aprende através de seus membros individuais, sendo então a organização afetada, direta e indiretamente, pela aprendizagem individual. Argyris e Schon (apud KIM, 1998, p.71) propõem, em sua teoria, que a aprendizagem organizacional ocorre através de atores 
individuais, cujas ações são baseadas em um conjunto de modelos mentais compartilhados. Ou seja, as pessoas, a partir de suas diferentes formas de ver e interagir com o mundo, compartilha opiniões a respeito de uma determinada situação e, com essas trocas, acabam aprendendo novas maneiras de proceder diante da mesma. Obviamente, não é somente a visão de uma pessoa, ou mesmo o compartilhamento de visões, que influencia nos procedimentos de uma organização. As organizações, em geral, já possuem procedimentos e normas definidas, que compõem e são parte importante da memória organizacional. Muitas vezes, dependendo do tipo da organização e do tipo de decisão a ser tomada, essas normas e procedimentos vão prevalecer sobre as decisões individuais.

Outro detalhe deste modelo, que o autor chama de ciclo OADI de modelos mentais compartilhados, é o fato de que ele torna clara a maneira como ocorre a transferência de aprendizagem nas organizações. Através do intercâmbio de informações entre as rotinas do indivíduo e as da organização (SOP - Standard Operating Procedures) e dos conceitos daquele e os conceitos organizacionais (weltanschauung), inevitavelmente acaba ocorrendo mudanças, tanto nos modelos mentais individuais quanto nos modelos mentais compartilhados (organizacionais).

Na figura 4, Kim (1998), consolida sua proposta. IDLL é a sigla de individual double loop learning - aprendizagem individual de duas voltas; ODLL - sigla de organizational double loop learning - aprendizagem organizacional de duas voltas; ISLL - sigla de individual single loop learning - aprendizagem individual de uma volta; e OSLL é a sigla de organizational single loop learning - aprendizagem organizacional de uma volta. 


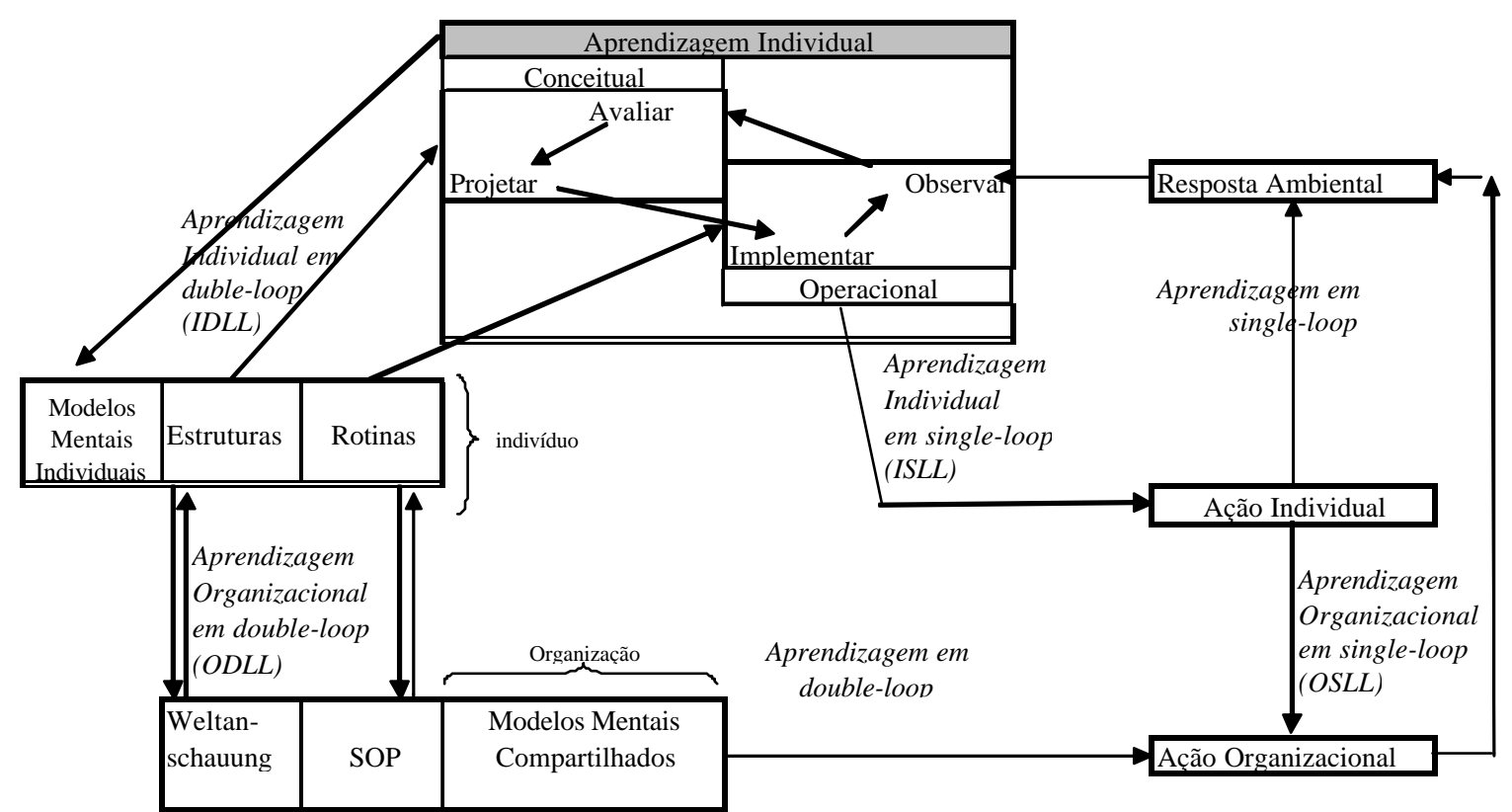

Figura 4 - Modelo integrado de AO: ciclo OADI de modelos mentais compartilhados.

Fonte: Adaptado de Kim, 1998, p.61-92

Explicando um pouco mais a figura 4, as empresas estão impregnadas de normas e procedimentos, que ditam suas formas de ação e muitas vezes criam paradigmas. Essas normas e procedimentos padronizados de operações, denominados por Kim (1998, p.71) de SOP (standard operating procedures), estão relacionados com a memória operacional e, se não trabalhados devidamente com o weltanschauung, que representa a memória conceitual da organização (cultura, valores, políticas), tendem a gerar paradigmas e fazer com que a empresa mantenha o mesmo modelo de ação durante anos, ou seja, impossibilitam a passagem do modelo single-loop para o double-loop learning. A transição do modelo single-loop para o modelo doubleloop pede como meio uma cultura organizacional de aprendizagem contínua. Para isso, é preciso que as pessoas, que compõem a organização, utilizem mais a parte conceitual do que a operacional de seus modelos mentais, e, ainda, é preciso que ocorra uma interação intensiva entre os modelos mentais individuais e compartilhados, como demonstra a figura 3.

Interligando as premissas apresentadas na figura 3 com a questão do agir organizacional, percebe-se a importância do modelo de gestão permitir práticas de aprendizagem organizacional em double loop, pois, em organizações que atuam sob a tutela dos sistemas pré-construídos, em single- 
loop (mecanicista e organicista), a aprendizagem estaria limitada a áreas e indivíduos específicos, bem como voltada para sua manutenção e operação, portanto, seus efeitos evolutivos estariam impedidos de ser ampliados para a organização, conseqüentemente, a aprendizagem organizacional estaria constrangida.

Kolb (1984) enfatiza que o aprendizado está condicionado à capacidade de percepção e de ação do sujeito sobre seu ambiente, não havendo aprendizado perante apenas um destes processos. Além disso, ressalta que, apesar da aprendizagem ser um ciclo, existem variações neste processo, ora enfatizando um eixo, ora outro, caracterizando, assim, a individualidade dos sujeitos. Isso se dá devido às influências do ambiente sobre o indivíduo, pois, se a aprendizagem é um processo de adaptação, como visto, o próprio processo está sujeito a adaptar-se conforme as exigências do ambiente

The simple perception of experience is not sufficient for learning; something must be done with it. Similarly, transformation alone cannot represent learning, for there must be something to be transformed, some state or experience that is being acted upon. (KOLB, 1984; $\mathrm{p}$. 42) ${ }^{2}$

\section{3) Concepções Da Formação Na Perspectiva Do Agir Organizacional}

Segundo Maggi (2006, p.169), não se pode refletir sobre a organização desconsiderando-se a aprendizagem, nem pensar na formação sem se referir ao processo organizacional. Uma implica a outra, concebidas de acordo com a maneira de ver adotada. Toda atividade de formação é um processo de agir social e até mesmo agir organizacional, sendo que neste sentido a teoria do agir do agir organizacional revela-se uma teoria da formação.

Desta forma, deve-se refletir sobre as concepções referente a formação, que envolve, a identificação e a explicação das diferentes orientações

\footnotetext{
${ }^{2}$ A simples percepção da experiência não é suficiente para a aprendizagem; algo deve ser feito com ela. Da mesma forma, a transformação sozinha não pode representar a aprendizagem já que é preciso ter algo a ser transformado, algum estado ou experiência no qual se está agindo.
} 
filosóficas a partir das quais se podem considerar os temas e os problemas da formação. Para voltar às concepções de formação, é preciso, antes de tudo, livrar-se das opiniões adotadas e difundidas sem discussão e até dos preconceitos.

Um preconceito do qual convém se desfazer, refere-se a definição da formação como "saber", como, informação e transmissão do conhecimento, "saber-fazer", como, aprendizagem operacional e prática de comportamento, e "saber-ser", como, integração de condutas, de motivações e tomada de consciência. Essa formação apóia-se na idéia muito restritiva do conhecimento e no pressuposto de que são possíveis conhecimentos e comportamento separados de valores. Caso se supere este preconceito possa-se ao menos identificar diversas representações possíveis de "saber, saber-fazer e saberser".

Pode-se definir um sistema social em termos de: (a) papeis interconectados, formalmente prescritos e imutáveis. Identifica-se com a abordagem mecanicista: a formação é uma aprendizagem de tarefas e responsabilidades e volta-se a designação e modelagem dos objetivos e dos valores do sujeito segundo as exigências do sistema; (b) relativamente variáveis e adaptáveis no quadro de funcionalidade. Identifica-se com a abordagem orgânica: formação para papéis, encontro de prescrições e expectativas emanando do sistema e de expectativas e motivações do sujeito e volta-se a designação e modelagem dos objetivos e dos valores do sujeito segundo as exigências do sistema. (c) papeis assumidos por sujeitos. Identifica-se com epistemologia e pragmatismo: formação como auxilio às estratégias dos sujeitos, sustentado nos objetivos e valores dos sujeitos em oposição aos constrangimentos do sistema. (d) Processos. Identifica-se com a abordagem relacional: a formação não é um instrumento nem da adaptação, nem de oposição ao sistema, e sim, um instrumento de escolha de ação, objetivos e valores.

Maggi (2006, p.169) salienta que é possível evidenciar diferentes maneiras de representar as relações entre organização e formação, e as suas implicações. Também é possível trabalhar as relações entre análise de 
trabalho, intervenção para mudança e formação, assim como a relação entre análise da mudança e desenvolvimento de competências, mostrando o ponto de vista da teoria do agir organizacional. O autor (2006, p.170) concebe a formação como saber, saber-fazer e saber ser, considerando um sistema social em termos de papéis assumidos, os níveis de saber, saber-fazer e saber-ser está voltado para a sustentação dos objetivos e dos valores dos sujeitos em oposição aos constrangimentos do sistema.

Ao considerar um sistema social em termos de processo, sendo este sistema o processo de ações e decisões intencionalmente orientadas, a formação não é um instrumento nem da adaptação, nem de oposição ao sistema, mas ao contrário um instrumento de escolha de ação, objetivos, valores. Dessa forma, o processo não é nem pré-determinado, nem inevitavelmente constrangedor, mas intencionalmente concebido e continuamente remanejado e modificado (MAGGI, 2006, p.171)

Em resumo, Segundo Maggi (2006, p181): o processo de formação é:

- $\quad \mathrm{Na}$ lógica dos sistemas, uma conseqüência de atividades heterogêneas entre as quais uma, a atividade de formação, é central; as outras, que a precedem ou a seguem, são funcionais em relação a ela;

- Na lógica do ator, um desenvolvimento de reflexão, de pensamento, de tomada de consciência, realizado num meio de formação formalizado e separado do agir cotidiano;

- $\quad$ Na lógica do agir, um curso de ações e decisões orientadas, ao mesmo tempo, interno a e suporte da auto-organização de um processo social mais amplo. “

Pode-se argumentar que as concepções - em conseqüência as teorias, métodos e práticas - não são suscetíveis de comparação. Se ao contrário, é admitido confrontá-las, é necessário então, acima de tudo, saber deter-se em cada concepção para apreender amplamente suas características e sua coerência interna ou, aceitar maneiras diversas e contrastadas de ver a formação. 
Segundo Maggi (2006, p.198), a perspectiva do processo trata de uma análise da organização, sendo nesse sentido a mudança sempre compreendida como uma mudança de organização. A análise organizacional permite aos sujeitos aprender um método e, portanto, integrar um saber de análise organizacional em suas competências. De acordo com o autor, o enriquecimento das competências dos sujeitos pelo saber de análise organizacional thes dá a capacidade de compreender a pré-ordenação do processo de trabalho, bem como de intervir conscientemente em sua mudança. Na perspectiva do processo, a aprendizagem organizacional - decorre de sua produção e mudança contínua, e as relações entre análise, mudança, formação, expressam essa aprendizagem enquanto característica intrínseca (MAGGI, 2006, p.204).

As competências da empresa significam o que ela sabe fazer bem, uma capacidade, um saber fazer de alta qualidade. Enquanto a competência do sujeito é um conjunto de atributos que estão em relação com o desempenho de uma tarefa (Maggi, 2006, p.214). Competência, portanto é "saber fazer", no caso da competência do agir organizacional é o "saber compreender" as contradições e os efeitos intuitivos do sistema (Maggi, 2006, p. 221).

Sobre a competência para a mudança organizacional, Maggi (2006, p.223) afirma que pode ser concebido como saber avaliar e saber julgar o processo de ação, em particular sua regulação, sendo que a competência entendida desse modo só pode se formar e se reformar no processo.

Distinguem-se diferentes conceitos dentro do campo de estudo de formação, sendo eles: competência, capacidade e conhecimento. $O$ conhecimento relaciona-se com o saber, no entanto, não se equivalem, sendo este a interiorização do saber, aquilo que se sabe após diversas aprendizagen s. A capacidade caracteriza-se como um conjunto de características individuais ou coletivas, tendo a prioridade de poderem ser descontextualizadas de uma prática e transferidas para outros contextos, e a competência, corresponde à qualidade que se confere em relação a uma ação determinada.

Coloca-se a competência para a mudança organizacional como saber avaliar e saber julgar o processo de ação, em particular sua regulação. A 
avaliação e o julgamento se expressam sobre a ação e na ação, na medida em que esta é ao mesmo tempo intrinsecamente constitutiva de um processo e estruturada num processo. Portanto, a competência se forma e reforma a partir do processo (de aprendizagem) e não exclui a referência a conhecimentos que se pode adquirir de saberes disciplinados que podem ser cultivados e enriquecidos.

Dentro de tal discussão observam-se os dispositivos de formação e análise. Estes correspondem a uma visão particular da formação, que é vista como uma reflexão do processo organizacional sobre si mesmo, sendo ela própria também um processo de ações e decisões orientado para o resultado esperado, que é ajudar na congruência do processo primário do trabalho em sua globalidade.

Os dispositivos se baseiam no encontro de três eixos. O primeiro é o dos saberes metodológicos provenientes da teoria do agir organizacional, na qual os sujeitos precisam desses saberes para analisar, avaliar e modificar seu processo. O segundo é o das competências específicas dos sujeitos do processo, em que, é a partir de suas competências, inerentes às ações de trabalho, e nelas e por elas desenvolvidas, que os sujeitos podem apropriar-se do método do qual necessitam. E o terceiro é o da epistemologia que a abordagem pressupõe que colocam em relação os saberes metodológicos do agir organizacional e as competências intrínsecas ao processo de trabalho.

A análise do trabalho e da formação, portanto, são dois aspectos do mesmo dispositivo. A análise do processo de trabalho é simultaneamente uma intervenção de mudança desse processo, de modo que a análise e a intervenção aparecem unidas, como e ao mesmo tempo em que a análise e a formação no curso da abordagem utilizada. A maneira de ver objetivista, a análise, habitualmente na forma de um documento escrito, pode ser utilizada ou não para a intervenção no trabalho, e é bastante raro que o pesquisador esteja implicado nessa decisão. Do ponto de vista subjetivista, a análise, a intervenção e o trabalho são atividades separadas. A análise cabe lembrar, é propriamente uma compreensão da construção da realidade do trabalho. A tomada de consciência não deixa de ter conseqüências nas atitudes e nos 
comportamentos dos sujeitos da realidade de trabalho. Na medida em que se admite que o objetivo da intervenção é mudar a organização, problemas importantes emergem para a visão subjetivista. Esta implica uma concepção da organização como resultado de uma institucionalização que só pode se conhecer a posteriori.

Os sujeitos, portanto, estão em condição de compreender a estruturação do processo de trabalho, de decodificar as condições organizacionais existentes naquele momento e de representar e avaliar as possíveis alternativas de mudanças organizacionais. Eles compreendem seus processos de trabalho considerando seus efeitos de outras soluções organizacionais possíveis e, por outro lado, eles o mudam escolhendo a solução mais satisfatória. Dessa maneira, a análise e intervenção são dois aspectos, não separáveis na abordagem adotada, da mesma ação desenvolvida pelos sujeitos sobre seu próprio processo de trabalho.

Que todos os sujeitos que de alguma maneira participam da regulação do processo devam participar em suas mudanças, até em seu monitoramento, é apenas uma conseqüência da maneira de ver; mas isso evidentemente não implica que esses sujeitos estejam de acordo. Este esclarecimento remete a ação sindical que, será tanto mais fecunda quanto mais todos os sujeitos envolvidos compartilharem a mesma maneira de ver em termos de processo: a organização, o trabalho e a prevenção.

A perspectiva do processo implica que a análise e a intervenção sejam dirigidas pelas competências ligadas ao trabalho, ou seja, as competências dos sujeitos agindo no processo e trabalho. Além disso, a perspectiva do processo implica que às competências de trabalho se unam às competências de análise organizacional com fins de prevenção.

Cabe ressaltar que a interpretação de competência muda radicalmente quando se toma distância das correntes funcionalistas e contingencialistas e se busca uma aproximação das análises dos processos de trabalho que privilegiam a dimensão temporal deste processo de ação e que as maneiras de ver a competência, enraizadas nas opções epistemológicas das ciências 
humanas e sociais, servem para explicar não somente as diferenças das abordagens não se produziram numa sucessão cronológica.

As maneiras fundamentais de ver a competência não são comparáveis, no entanto, podem ser colocadas lado a lado, para apreender suas características similares e divergentes.

Assim, o conhecimento está em relação com o saber, mas não é equivalente a ele: ele é uma interiorização do saber, aquilo que se sabe após diversas aprendizagens. A capacidade é outra coisa ainda: um conjunto de características individuais ou coletivas, tendo a prioridade de poderem ser descontextualizadas de uma prática e transferidas para outros contextos. A competência enfim, é uma qualidade que se confere em relação a uma ação determinada.

\subsection{1) Ambiente De Trabalho Necessário}

Frente a toda conceituação e discussão a respeito dos processos de aprendizagem pode-se sintetizar algumas características a eles fundamentais para sua viabilização nas organizações. Embora aprendizagem individual e organizacional seja mutuamente influenciada em si, para efeito de estudo, tentaremos separar as condições ideais para um e para outro.

Conforme a conceitualização de Nonaka e Takeuchi (1995), ressalta-se que todo conhecimento surge do processo de aprendizagem individual, portanto, para haver aprendizagem organizacional, é preciso que os sujeitos se encontrem em uma situação constante de aprendizagem. Observando que a externalização do conhecimento é facilitada pelo uso de uma linguagem abstrata, fazendo uso de metáforas e analogias, enquanto que a combinação depende de uma linguagem objetiva, uma característica necessária à aprendizagem organizacional é a flexibilidade no modo de comunicar-se, possibilitando adaptações na comunicação conforme a necessidade e os aspectos do conhecimento em questão (tácito ou explícito). 
Ainda sobre a comunicação, além de flexível, ela deve ser abundante. Segundo Nonaka e Takeuchi (1995), ela deve ser redundante no sentido de ser disponibilizada e acessada por todos de forma ilimitada, mantendo um fluxo intenso de informação, mesmo para os sujeitos que aparentemente não necessitam dela. Além disso, o ambiente também precisa viabilizar a reflexão coletiva sobre as experiências da organização, ou seja, disponibilizar pessoas e tempo para analisar e estudar as situações relevantes para a organização de forma conjunta, depois de análise prévia individual. Para isso, deve-se manter interação entre os sujeitos, facilitando discussões e trocas de idéias, além da possibilidade de observação do trabalho dos demais envolvidos para sua compreensão e apreensão.

Nonaka e Takeuchi (1995) ressaltam ainda a importância do caos criativo para a aprendizagem organizacional, dizendo que é preciso um ambiente de trabalho dinâmico, com vivência de circunstâncias incertas e quebras de rotina que levam ao questionamento dos conceitos existentes. Os sujeitos nas organizações devem ter atividades amplas para possibilitar que eles vivenciem essas situações diversas e lidem com imprevistos.

Em relação à aprendizagem individual, percebe-se que ela deve respeitar as características de aprendizagem pessoais. De acordo com Kolb (1984), relembrando a noção de aprendizagem como forma de adaptação ao meio, cada indivíduo aprende de um jeito específico e em um tempo próprio, portanto, a aprendizagem não deveria ser delimitada pela imposição de superiores. A imposição prejudica a aprendizagem por limitar o apelo vital do processo e impedir o despertar de interesse do sujeito sobre o tema a ser aprendido. $O$ ambiente tem que proporcionar aos trabalhadores 0 conhecimento do "porquê" e do "para quê".

O ambiente ainda deve amenizar preconceitos e restrições à novas experiências concretas para possibilitar que os trabalhadores envolvam-se com ela e dêem início ao ciclo descrito por Kim (1998). Para dar continuidade ao processo de aprendizagem a partir da experiência concreta, é preciso que o sujeito tenha disponibilidade, conforme seu tempo e suas necessidades, para refletir sobre a experiência vivenciada, analisá-la e estudá-la, contando com o 
apoio de outras pessoas que também acompanharam a experiência em questão, mas não se envolveram diretamente nela, oferecendo feedback. A análise da experiência é complementada com o acesso a teorias relacionadas, que auxiliam na fase de conceitualização abstrata.

Por fim, é fundamental que o sujeito tenha autonomia para realizar novas experiências a partir do que ele estudou, concretizando o ciclo da aprendizagem e criando novos conhecimentos. A aprendizagem ficará comprometida caso o sujeito participe das experiências, as analise e as conceitualize, mas não tenha condições de aplicação dos novos conceitos formulados e de sua comprovação. Realizando a aprendizagem em circuito único. Sucintamente, as características organizacionais que possibilitam a realização efetiva dos processos de aprendizagem individual e organizacional são:

Quadro 3 - Condições necessárias ao processo de aprendizagem

\begin{tabular}{|c|c|}
\hline INDIVIDUAL & ORGANIZACIONAL \\
\hline Ausência de imposição da aprendizagem. & Flexibilidade na comunicação. \\
\hline $\begin{array}{l}\text { Respeito ao tempo e ao jeito de cada } \\
\text { sujeito durante a aprendizagem. }\end{array}$ & Reflexão coletiva sobre as experiências. \\
\hline $\begin{array}{l}\text { Conhecimento do porquê e para quê } \\
\text { aprender. }\end{array}$ & $\begin{array}{l}\text { Possibilidade de observar o trabalho dos } \\
\text { demais envolvidos. }\end{array}$ \\
\hline $\begin{array}{l}\text { Ausência de restrições e preconceitos a } \\
\text { respeito de novas experiências. }\end{array}$ & $\begin{array}{l}\text { Todos os sujeitos em processo de } \\
\text { aprendizagem individual. }\end{array}$ \\
\hline $\begin{array}{l}\text { Disponibilidade para refletir sobre as } \\
\text { experiências. }\end{array}$ & Constante interação entre os sujeitos. \\
\hline $\begin{array}{l}\text { Apoio de pessoas que não participaram } \\
\text { diretamente da experiência. }\end{array}$ & Atividades amplas que lidam com imprevistos. \\
\hline Processo de feedback constante. & $\begin{array}{l}\text { Autonomia para os sujeitos resolverem os } \\
\text { imprevistos. }\end{array}$ \\
\hline $\begin{array}{l}\text { Acesso a teorias a respeito da } \\
\text { experiência. }\end{array}$ & $\begin{array}{l}\text { Vivência de circunstâncias incertas e quebras } \\
\text { de rotina. }\end{array}$ \\
\hline Autonomia para novas experiências. & Redundância de informação. \\
\hline
\end{tabular}

Fonte: Kolb (1984;97); Nonaka e Takeuchi (1995); Kim (1998); Maggi (2006)

Sucintamente, as relações hipotéticas entre as maneiras de ver a organização segundo as racionalidades propostas por Maggi e seus constrangimentos à aprendizagem são: 
Quadro 4 - Relações hipotéticas entre concepções e constrangimentos à aprendizagem

\begin{tabular}{|c|c|c|}
\hline CONCEPÇÕES & $\begin{array}{c}\dot{A} \text { APRENDIZAGEM } \\
\text { INDIVIDUAL }\end{array}$ & $\begin{array}{l}A \text { APRENDIZAGEM } \\
\text { ORGANIZACIONAL }\end{array}$ \\
\hline $\begin{array}{l}\text { - SISTEMA SOCIAL } \\
\text { PRÉ- } \\
\text { DETERMINADO EM } \\
\text { RELAÇÃO AOS } \\
\text { SUJEITOS } \\
\text { AGENTES } \\
\\
\text { MECANICISTA }\end{array}$ & $\begin{array}{ll}\text { - } & \text { Imposição da aprendizagem } \\
\text { - } & \text { por superiores. } \\
& \text { apreno e modizagem de } \\
\text { - } & \text { Ausência de apelo vital. } \\
\text { - } & \text { Restrições e preconceitos a } \\
\text { novas experiências. } \\
\text { - } \quad \text { Ausência de feedback. } \\
\text { - } \quad \text { Ausência de acesso a fontes } \\
\text { - } \quad \text { de informação diversas. } \\
\text { realizar novas experiências. }\end{array}$ & 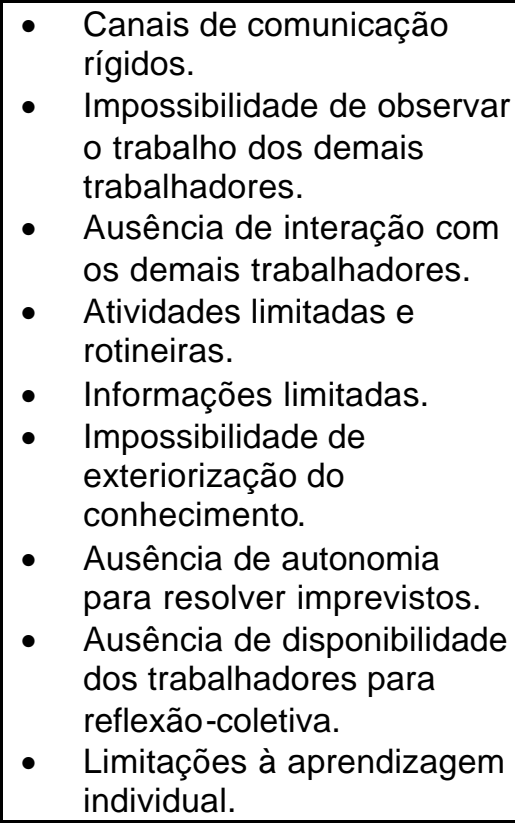 \\
\hline $\begin{array}{l}\text { - SISTEMA SOCIAL } \\
\text { PRÉ- } \\
\text { DETERMINADO EM } \\
\text { RELACCÃO AOS } \\
\text { SUJEITOS } \\
\text { AGENTES } \\
\text { ORGANICISTA }\end{array}$ & $\begin{array}{l}\text { - } \quad \text { Imposição da aprendizagem } \\
\text { por superiores. } \\
\text { - } \quad \text { Tempo e modo de } \\
\text { aprendizagem padronizada. } \\
\text { - } \quad \text { Restrições e preconceitos a } \\
\text { novas experiências. } \\
\text { - } \quad \text { Limitações ao acesso a } \\
\text { fontes de informação } \\
\text { diversas. } \\
\text { - } \quad \text { Ausência de autonomia para } \\
\text { realizar novas experiências. }\end{array}$ & $\begin{array}{ll}\text { - } & \text { Ausência de autonomia } \\
& \text { para resolver imprevistos. } \\
\text { - } & \text { Alto grau de estabilidade } \\
& \text { dos processos realizados. } \\
\text { - } & \text { Limitações à reflexão } \\
& \text { coletiva. } \\
\text { - } & \text { Limitações à aprendizagem } \\
\text { individual. }\end{array}$ \\
\hline $\begin{array}{l}\text { SISTEMA SOCIAL } \\
\text { CONSTRUÍDO } \\
\text { PELAS } \\
\text { INTERAÇÕES DOS } \\
\text { SUJEITOS }\end{array}$ & $\begin{array}{ll}\text { - } & \text { Ausência de apelo vital. } \\
\text { - } & \text { Desconhecimento dos } \\
\text { - } & \text { objetivos da aprendizagem. } \\
& \text { nestrições e preconceitos a } \\
\text { - } & \text { Limitações ao acessesso a } \\
& \text { fontes de informação } \\
& \text { diversas. } \\
\text { - } & \text { Ausência de autonomia para } \\
& \text { realizar novas experiências. }\end{array}$ & 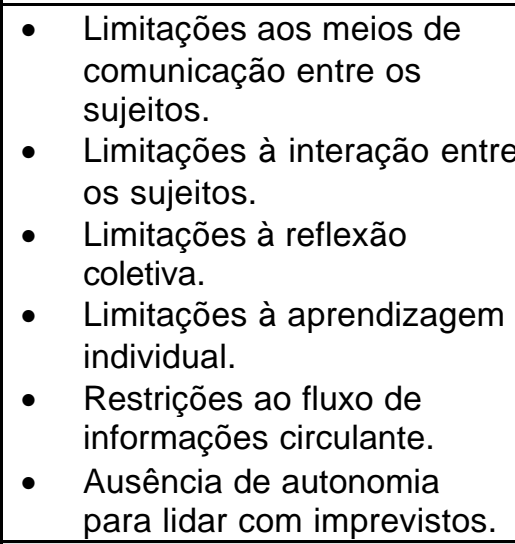 \\
\hline $\begin{array}{l}\text { - AGIR } \\
\text { ORGANIZACIONAL } \\
\text { - PROCESSO DE } \\
\text { AÇÕES E } \\
\text { DECISÕES } \\
\end{array}$ & Não identificado. & Não identificado. \\
\hline
\end{tabular}

Fonte: a autora 


\section{7.) PROCEDIMENTOS METODOLÓGICOS}

É por meio de métodos que a ciência alcança uma maior probabilidade de eficácia e ajuda a explicar compreender e concluir sobre aquilo que pesquisa. Todavia, ela - a ciência - só exerce tais papéis quando é construída pela correta utilização de métodos rigorosos e precisos. Por isso que a escolha do método de pesquisa é uma decisão que deve se dar a partir de uma meticulosa análise dos objetivos, da experiência e competência dos pesquisadores, bem como do contexto no qual se realiza o estudo, pois há várias técnicas e nenhuma delas é superior as demais.

Segundo Morin (2000, p.335), o método, alimentado de estratégia, iniciativa, invenção e arte, estabelece uma relação com a teoria capaz de propiciar a ambos regeneração mútua por meio da organização de dados e informações. Assim, o método é o instrumento de orientação do pesquisador, pois, se houver a necessidade de reconstrução da teoria ou do método, é de suma importância conhecer-se o caminho seguido para se chegar às informações. O método é um processo e não um produto, não deve atuar como um rótulo que cerceia a criatividade, mas sim como uma ferramenta orientadora a serviço do pesquisador.

No campo das ciências sociais aplicadas, a realização de pesquisas tem sido fortemente influenciada por métodos quantitativos nas descrições e explicações de interesse. Nos dias atuais, contudo, verifica-se uma abordagem que, gradualmente, se estabelece como uma alternativa de investigação e que permite gerar condições mais abrangentes e holísticas em contextos organizacionais e sociais. Trata-se da pesquisa qualitativa. (GODOY, 1995)

A pesquisa qualitativa apresenta características alinhadas aos propósitos do presente estudo, pois tem o ambiente natural como fonte direta de dados e o pesquisador como instrumento fundamental. Ela é descritiva, pois visa descrever a realidade da organização pesquisada no que tange a constrangimentos e processos de formação e aprendizagem à luz da teoria do agir organizacional. O significado que as pessoas dão às coisas e à sua vida é a preocupação essencial do investigador; no caso em estudo, focalizou-se no 
entendimento de como os entrevistados de acordo com sua racionalidade atuam frente à estruturação dos processos de formação e aprendizagem existentes.

Esse tipo de pesquisa tem o enfoque indutivo como base para a análise de seus dados. Os pesquisadores qualitativos estão preocupados com o processo e não simplesmente com os resultados e o produto; no caso, discutir o processo de formação e aprendizagem a partir da perspectivas do agir organizacional. (BOGDAN, apudGODOY, 1995)

Demo (2001, p.51) salienta, ainda, que a pesquisa qualitativa se faz mister quando se está diante de um campo sujeito-objeto marcado por tessituras intensas, profundas e não lineares da convivência e da comunicação humanas. Ou seja, envolve horizontes caracterizados pela politicidade, perfectibilidade, profundeza e envolvência subjetivas, cujo fundo pode diferir muito da superfície. Desta forma, pelo paralelismo com os objetivos do trabalho e pela característica da situação pesquisada, a abordagem escolhida foi a qualitativa.

A presente pesquisa, levando-se em conta seu objetivo principal, caracteriza-se como um estudo de caso exploratório/descritivo. Pretende, a partir do contato com os elementos da população em estudo, obter maior familiaridade com fenômenos relativamente desconhecidos, criar condições para a realização de uma investigação mais completa, estabelecer prioridades para estudos futuros e aprimorar idéias, já em prática, no intuito de estimular a compreensão dos fenômenos pesquisados (aprendizagem e seus constrangimentos). (SELLTIZ et al., 1987; TRIVINOS, 2002, p.110; SAMPIERI et al., 1991, p. 59-60)

Para o desenvolvimento do estudo foram utilizados, como métodos de coleta de dados principais, a pesquisa bibliográfica, a análise documental e a entrevista em profundidade e, complementarmente, a observação. 


\section{1) Detalhamento dos procedimentos metodológicos}

Objetivando particularização e aprofundamento, optou-se pelo estudo de caso, que se define como uma categoria de pesquisa cujo objeto é uma unidade, que se analisa aprofundadamente. Tal tipo de pesquisa pode partir de alguns pressupostos teóricos, aos quais novas concepções podem ser acrescentadas no decorrer do estudo. De acordo com Yin (2001) e Lazzarini (1995), o método do estudo de caso é considerado condizente sempre que estiver em harmonia total com o problema que está se analisando e deve ser utilizado quando: as situações analisadas são contemporâneas, abrangentes e complexas; o fenômeno não pode ser estudado fora de seu contexto, sem perda de utilidade da pesquisa; o foco maior é a compreensão dos fatos e não sua mensuração; e, há possibilidade de utilizar várias fontes para evidenciar os fatos.

As características que suportam o uso do estudo de caso, nesta pesquisa, portanto, seguindo a ordem apresentada por Yin e Lazzarini são respectivamente: aprendizagem organizacional como tema contemporâneo ainda em construção, realidade hospitalar exigindo diferentes perspectivas de aprendizagem, busca não da mensuração, mas da compreensão da relação concepções organizacionais (racionalidades), constrangimentos e processos de formação e aprendizagem, e uso de três fontes de coleta: pesquisa documental, bibliográfica e entrevista em profundidade.

O estudo de caso apresenta caráter preponderantemente qualitativo. Para Cassel e Symon (1994), uma abordagem qualitativa é mais focada em temas emergentes e em descrições ideográficas, sendo menos œnduzida por hipóteses muito específicas e mais por estruturas categóricas, o que proporciona maior flexibilidade no processo de pesquisa e fornece uma visão holística de situações ou organizações que os pesquisadores estão procurando entender. O que conflui para o objetivo de compreender os processos de aprendizagem frente aos constrangimentos provocados pelas racionalidades em prática. Estas inter-relações têm sido pouco exploradas e não há registro de estudos aprofundados sobre elas, até o momento. Esses fatos exigiram 
proximidade com os sujeitos e objetos pesquisados, para que fosse alcançada a visão holística do fenômeno. A seguir, são apresentadas algumas definições, no sentido de corroborar a utilização do estudo de caso nesta tese.

Na visão de Cooper \& Schindler (2003, p.130),

\begin{abstract}
"os estudos de caso colocam mais ênfase em uma análise contextual completa de poucos fatos ou condições e suas inter-relações. Embora as hipóteses sejam freqüentemente usadas, basear-se apenas em dados qualitativos torna o suporte ou a rejeição mais difícil. Uma ênfase em detalhes fornece informações valiosas para soluções de problemas, avaliação e estratégia. Esse detalhe é obtido de fontes múltiplas de informação. Permite que as provas sejam verificadas e evita a perda de dados."
\end{abstract}

Na visão de Yin (2001, p.19), "o estudo de caso é apenas uma das muitas maneiras de se fazer pesquisa em ciências sociais". O autor complementa relatando que: "em geral, os estudos de caso representam a estratégia preferida quando as questões são do tipo 'como' e 'por quê', quando o pesquisador tem pouco controle sobre os eventos e quando o foco está em fenômenos contemporâneos inseridos em algum contexto da vida real."

Ainda segundo Yin (2001), pode-se trabalhar com estudo de casos múltiplos ou com um único caso; este último foi opção da presente tese, pois é apropriado quando: é revelatório, ou seja, é situação previsivelmente inacessível para investigação científica; representa caso crítico para testar teoria bem formulada; é extremo ou único. A organização pesquisada, como já relatada, apresenta informações singulares, uma vez que possui características de diferentes complexidades em um único local, fato que permite a discussão que apontará erros e acertos nos quais a organização incorre em gestão frente a aprendizagem.

Para o desenvolvimento do estudo, foram utilizados os seguintes passos em relação à construção das informações (vide detalhamento no quadro 5 e 6): a) Revisão e discussão da literatura existente, no intuito de construir a base teórica, que dará suporte à análise empírica. b) No intuito de compreender os aspectos afeitos às concepções organizacionais (racionalidades) e à aprendizagem e suas respectivas inter-relações, entrevistas em profundidade com pessoas consideradas "chave" para 
compreensão do fenômeno - as pessoas foram escolhidas tendo como base pelos menos um de três critérios: pessoas que ocupam cargos de direção (por entender que são os direcionadores de ações), pessoas que participam do processo de planejamento, por serem as mais bem informadas sobre o modelo e contexto organizacional e funcionários, considerados os usuários do sistema. Um perfil sintético dos entrevistados encontra-se no quadro 7. E c) No intuito de contextualizar, objetivar e enriquecer a análise da racionalidade adotada, utilizourse a análise documental, a qual se deu por meio de documentos disponibilizados pela organização, como relatórios, descrições do organograma, esquema de definição de treinamentos e históricos.

Assim, a coleta de dados se deu por meio de pesquisa bibliográfica, análise documental e entrevista em profundidade, conforme detalhado no quadro 5, na diretoria de enfermagem, considerada a área mais próxima da lógica de prestação de serviços no hospital pesquisado.

Quadro 5 - Protocolo dos Mecanismos (Instrumentos) de coleta de dados

\begin{tabular}{|c|c|c|c|}
\hline Mecanismos & Objetivo & Fonte & Referência \\
\hline $\begin{array}{l}\text { Pesquisa } \\
\text { bibliográfica }\end{array}$ & $\begin{array}{llr}\text { Definir, } & \text { fundamentar } & \text { e } \\
\text { discutir os temas da } \\
\text { pesquisa. }\end{array}$ & $\begin{array}{l}\text { Diversas } \\
\text { bibliográficas }\end{array}$ & $\begin{array}{lll}\text { Pesquisa em livros, } & \text { em de } \\
\text { periódicos, anais de } & \text { sites da } \\
\text { eventos, } & \\
\text { Internet e correlatos } & \end{array}$ \\
\hline $\begin{array}{l}\text { Pesquisa } \\
\text { documental }\end{array}$ & $\begin{array}{lr}\text { Buscar registros } & \text { sobre as } \\
\text { bases do } & \text { modelo } \\
\text { implementado } & \text { na } \\
\text { organização e práticas de } \\
\text { aprendizagem }\end{array}$ & 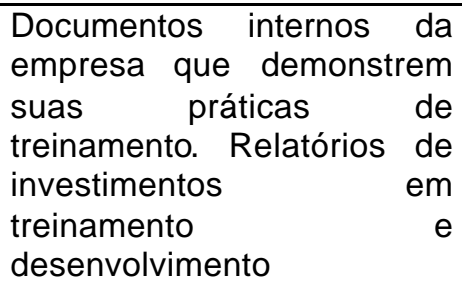 & $\begin{array}{l}\text { Banco de dados da } \\
\text { área de } \mathrm{RH} \text { e relatórios } \\
\text { anuais e semestrais da } \\
\text { empresa }\end{array}$ \\
\hline $\begin{array}{l}\text { Entrevistas em } \\
\text { profundidade }\end{array}$ & $\begin{array}{lr}\text { Identificação } & \text { dos } \\
\text { constrangimentos à } & \text { aprendizagem, bem como } \\
\text { das características da } \\
\text { estruturação da formação. }\end{array}$ & $\begin{array}{l}\text { Pessoas consideradas as } \\
\text { mais "entendidas" sobre o } \\
\text { modelo de gestão e } \\
\text { consideradas as mais } \\
\text { "importantes" } \\
\text { condução para das ações } \\
\text { pertinentes a } \\
\text { pesquisada }\end{array}$ & $\begin{array}{l}\text { Pessoas-chave } \\
\text { diretor, chefes } \\
\text { funcionários. }\end{array}$ \\
\hline
\end{tabular}

Fonte: a autora 
De forma a proporcionar uma visão ampliada do estudo realizado, resumiu-se no quadro abaixo, o roteiro seguindo para se chegar às respostas principais da pesquisa.

Quadro 6 - Protocolo do Estudo de Caso

FASE 1 - IDENTIFICAÇÃO DAS EXIGÊNCIAS DE FORMAÇÃO E APRENDIZAGEM DO AMBIENTE ANALISADO. Frente às características da diretoria de enfermagem identificou-se, em linhas gerais (questões técnicas, comportamentais e relacionais), o que seria fundamental aprender e por que.

FASE 2 - IDENTIFICAÇÃO DAS AÇÕES E DECISÕES DE FORMAÇÃO E APRENDIZAGEM PRATICADAS PELA DIRETORIA DE ENFERMAGEM. Nessa fase, com base na perspectiva da ação organizativa, analisou-se como se constrói e se desenvolve o agir regulador do processo de ações e decisões, ou, o agir estruturante, frente aos processos de formação e aprendizagem. Para se chegar a essas informações foram levantados:

- Orientações para a definição das ações de formação e aprendizagem (intencionalidade);

- Razões para a implementação das ações de formação e aprendizagem (limites da racionalidade);

- Como acontecem os processos de formação? (Modalidades; intensidade; processo de execução; mecanismos de avaliação de resultados);

FASE 3 - Com as informações advindas das fases 1 e 2, discutiu-se o dilema da ação que perpassa a obra de Maggi (2006): a relação constrangimentos sociais/organizacionais e escolhas individuais. Sendo as escolhas individuais analisadas sob a perspectiva da ação organizativa ou organizante que se desenvolve ao longo do tempo e não de ações terminadas. Assim, verificout se e explicou-se divergências à luz da variabilidade do processo organizacional e sua estruturação face a incerteza. Buscourse respostas para as seguintes questões: como são construídos os processos de cooperação e coordenação em relação ao tempo (estabilidade/mutabilidade) e à forma (homogeneidade/heterogeneidade) e em relação à coordenação das ações técnicas e à coordenação das ações para o desenvolvimento de ações? 
(tendo em vista a formação) Como os sujeitos dominam o processo de trabalho? Como as ações são reguladas, de forma discricionária ou autônoma? Se a organização se produz pela produção de sua ordem: só é possível compreender 0 trabalho de organização abordando-o pela estruturação do processo, no caso, do processo de aprendizagem. Assim, quais são as maneiras de ver a formação? Como se dá a busca do saber, do saber-fazer e do saber-ser? Eles estão voltados para quê? Como se dá a vinculação do que se aprende com a realidade operacional? Qual "sistema" predomina? Buscou-se analisar na perspectiva das conseqüências sobre o processo de formação: necessidade e análise das necessidades, resultado e avaliação dos resultados, planificação e projetos, atividade e sujeitos da formação, de acordo com o proposto por Maggi (2006, p.181-184).

FASE 4 - Com as informações advindas das fases 1, 2, e 3, discutiram-se os constrangimentos principais à aprendizagem fixados à partir do referencial teórico (quadro $\mathrm{x}$ ) e sua relação com os sistemas sociais encontrados discutindo-os frente a seus processo organizativos e suas variações no tempo e na forma. Buscourse refletir sobre as questões da cooperação, autonomia, flexibilidade, enfim, da regulação do trabalho, e suas conseqüências nas decisões de como e do que aprender dos indivíduos. $O$ debate girará em torno da finalização do processo, da relação meios-fins, da racionalidade intencional e limitada, da estruturação do processo e sua articulação com outros processos. Enfocar-se-á a dialética dos processos de formação e da aprendizagem no contexto estudado, tendo como objetivo a compreensão do sentido intencional da ação e explicação em termos de causalidade adequada no desenvolvimento do processo.

Fonte: a autora

Optou-se pela entrevista em profundidade pelo fato dela não utilizar questionário estruturado e sim um roteiro, com tópicos a serem abordados conforme os objetivos da entrevista. Este roteiro permite a condução mais livre da conversa entre o entrevistador e o entrevistado, alcançando tessituras não explícitas. Fato realmente verificado levando-se em conta a transparência, a profundidade e a seriedade dos entrevistados no momento da entrevista. As 
questões dos roteiros foram elaboradas tendo como guias os objetivos da pesquisa e a base teórica. As questões do roteiro foram elaboradas a partir da discussão teórica e das entrevistas prévias realizadas com o gestor do setor escolhido para a pesquisa, sempre com o foco na busca da descrição e da análise do modelo em discussão. Preocupou-se também em re-descrever os dados junto com o entrevistado, buscando alinhamento $\infty \mathrm{m}$ as informações buscadas, como Clot (2006) explica:

\begin{abstract}
Nem explicação externa dada pelo pesquisador, nem simples descrição do vivido pelo sujeito, a análise associa explicação e compreensão quando a mesma atividade é re-descrita em um novo contexto. A 'boa' descrição é a re-descrição. Realizada em colaboração entre o pesquisador e os trabalhadores envolvidos, ela fornece muitas vezes a explicação esperada. (p. 130)
\end{abstract}

Em seguida, tendo em vista a validação do roteiro, desenvolveram-se as seguintes ações: verificações se atendiam aos objetivos da pesquisa, realizadas logo após as primeiras entrevistas; quando não atendiam eram feitas novas discussões com o gestor do setor pesquisado; depois de idas e vindas e respectivos refinamentos em algumas questões, chegourse ao roteiro apresentado no apêndice.

Quadro 7 - Relação de Entrevistados

\begin{tabular}{|c|c|c|c|}
\hline PESSOAS & $\begin{array}{c}\text { TEMPO DE } \\
\text { CASA }\end{array}$ & DATA & $\begin{array}{c}\text { DURAÇÃO DA } \\
\text { ENTREVISTA }\end{array}$ \\
\hline Diretora de Enfermagem & 18 anos & $19 / 03$ & $1,1 \mathrm{H}$ \\
\hline 3 Chefes de Unidades da \\
Diretoria de Enfermagem & $\begin{array}{c}\text { Média de 10 } \\
\text { anos }\end{array}$ & $\begin{array}{c}14 / 04 \\
17 / 4\end{array}$ & $3,5 \mathrm{H}$ \\
\hline 16 Enfermeiros & $\begin{array}{c}\text { Média de } 10 \\
\text { anos }\end{array}$ & $\begin{array}{c}24 / 03 \\
16 / 5\end{array}$ & $17,6 \mathrm{H}$ \\
\hline
\end{tabular}

Utilizou-se como fonte de informação primária a entrevista semiestruturada que é aquela que parte de certos questionamentos básicos, apoiados em teorias e hipóteses que interessam à pesquisa, e que, em seguida oferecem um amplo campo de informações ao entrevistado (TRIVIÑOS, 1992). 
Assim, foram realizadas e gravadas 20 entrevistas com profissionais considerados formadores de opinião, portanto com responsabilidades e atribuições que caracterizam o processo de decisão.

Todos os entrevistados possuem formação superior. Atuam em diferentes áreas da diretoria de enfermagem. Cabe destacar que em todas as entrevistas, além de abordar as questões previstas, o pesquisador tomou o cuidado de avançar para o assunto de uma nova questão apenas após o esgotamento da anterior. Todavia, houve situações nas quais o entrevistado espontaneamente abordava algum dos assuntos que ainda seriam investigados - o que provocava a alteração da ordem das questões -, mas isto não prejudicou o alcance dos resultados almejados. Ao mesmo tempo, como se tratava de uma entrevista semi-estruturada, questões complementares serviram para esclarecer ou aprofundar temas pertinentes à pesquisa.

As entrevistas aconteceram no período de março de 2008 a maio de 2008, envolvendo um total de 20 pessoas e 22,2 horas de gravação. Faz-se mister observar que, as opiniões não serão expostas de forma que haja probabilidade de identificação. $O$ objetivo é impossibilitar a identificação de quem disse o quê por parte da organização estudada; esta medida objetivou preservar o sigilo, mesmo não tendo isto sido solicitado. $O$ único que detém esta informação é o pesquisador.

\subsection{1) Instrumento de coleta de dados}

Adotou-se como estratégia de coleta de dados a entrevista em profundidade com um roteiro geral norteador e três específicos compostos por perguntas abertas, subdivididos em três percursos interdependentes (apêndice). Utilizourse uma linguagem o mais próxima possível do entendimento dos pesquisados sobre os temas.

Para a validação do roteiro de entrevistas foi realizado um pré-teste, em fevereiro de 2008, para observar a compreensão dos entrevistados em relação a pesquisa. Este pré-teste foi respondido por três gestores da unidade pesquisada no qual se verificou o entendimento de todas as questões, sendo 
que em alguns casos foram realizadas modificações necessárias no instrumento. O pré-teste foi fundamental para a construção do roteiro de entrevistas.

\subsection{2) Análise e Tratamento dos Dados}

Para análise e tratamento dos dados, utilizou-se a análise de conteúdo, que tem como pressuposto tornar objetivo o conteúdo das entrevistas realizadas. A referida análise utiliza um conjunto de técnicas de análise de comunicação, visando, por meio de procedimentos sistemáticos e objetivos de descrição do conteúdo das mensagens, obterem indicadores, quantitativos ou não, que permitam a inferência de conhecimentos relativos às condições de produção/recepção das mensagens. (BARDIN, 2004)

A presente tese, na busca dos indicadores supra, utilizou a triangulação de diversas fontes de dados (relatórios, entrevistas, discussão teórica e observação em segundo plano) para que as respostas aos objetivos ganhem consistência e sejam sustentáveis. A análise efetivourse classificando os pesquisados em entrevistados $1,2,3 \ldots 20$, numerados, portanto, de forma aleatória, não seguindo nenhum critério lógico.

Para Bardin (2004, p.42), pertencem ao domínio da análise de conteúdo:

"...todas as iniciativas que, a partir de um conjunto de técnicas
parciais mas complementares, consistam na explicitação e
sistematização do conteúdo das mensagens e da expressão deste
conteúdo, com o contributo de índices passíveis ou não de
quantificação [...] Esta abordagem tem por finalidade efectuar
deduções lógicas e justificadas, referentes à origem das mensagens
tomadas em consideração (o emissor e seu contexto, ou,
eventualmente, os efeitos dessas mensagens)".

A análise de conteúdo apresenta diferenças em relação à análise documental. Neste caso, Bardin (2004, p. 46) destaca que há diferenças no sentido de a primeira utilizar a mensagem como objeto de estudo e a segunda trabalhar com os documentos. Bardin (2004, p. 45) define, com base em J. 
Chaumier, a análise documental como sendo "uma operação ou um conjunto de operações visando representar o conteúdo de um documento sob uma forma diferente da original, a fim de facilitar, num estado ulterior, a sua consulta e referenciação". Bardin (2004, p.38) diz, ainda, que na análise de conteúdo "... o interesse não reside na descrição dos conteúdos, mas sim no que estes nos poderão ensinar, após serem tratados (por classificação, por exemplo), relativamente a 'outras coisas'...".

Especificamente na análise de conteúdo das entrevistas, utilizourse um modelo de análise adaptado de Moraes (1993;99), que sugere as seguintes etapas:

1) Preparação das informações: esta etapa foi realizada em dois momentos distintos: a) transcrição das entrevistas gravadas na íntegra e imediatamente após sua realização; e b) leitura flutuante, para destacar e selecionar aspectos pertinentes e relevantes ao estudo, tendo como base os objetivos propostos.

2) Unitarização ou transformação do conteúdo em unidades: esta etapa também foi realizada em dois momentos distintos: a) separação em parágrafos, de acordo com o conteúdo temático; e b) reelaboração das unidades de registro, por meio de uma síntese posterior de cada parágrafo, como recurso facilitador ao manuseio das informações, embora, mantendo constante preocupação em conservar, tanto o sentido original como as próprias palavras do entrevistado, relacionadas aos temas em discussão. Definidas pelo pesquisador, as unidades de análise podem ser palavras, frases, temas ou mesmo documentos integralmente. No caso utilizaram-se frases.

3) Categorização ou classificação das unidades em categorias: a categorização consiste em agrupar dados de acordo com a similitude que apresentam. Os critérios desta semelhança podem ser semânticos, o que origina categorias temáticas, sintáticos ou léxica, contudo deve seguir o mesmo critério em todo o estudo. Neste estudo, optou-se pela análise temática, agrupando-se as unidades de registro, a partir do desmembramento das várias entrevistas e unidades previstas no quadro 8. 
4) Descrição: no contexto da abordagem qualitativa, para cada uma das categorias será produzido um texto síntese no qual será expressado o conjunto de significados presentes nas diversas unidades de análise. Citações diretas serão utilizadas para exemplificar as informações.

5) Interpretação: desenvolvida a partir do arcabouço teórico constituído, além de valorizar a teoria que emergirá a partir dos próprios dados. A interpretação é o momento crucial da análise de conteúdo.

Segundo o mesmo autor, a análise de conteúdo, embora admita um número ilimitado de abordagens, tem historicamente se enquadrado em seis questões básicas: 1) "Quem fala?" 2) "Para dizer o quê?" 3) "A quem?" 4) "De que modo?" 5)"Com que finalidade?" 6) "Com que resultados?" No caso desta análise centrou-se nas questões "Para dizer o quê?", seu enfoque serão as características da mensagem, seu valor enquanto informação através de palavras e argumentos e "Com que resultados?", que procurará identificar e descrever os resultados efetivos das comunicações considerando que os resultados não necessariamente coincidirão com os objetivos mas permitirão explorar as incongruências entre fins e resultados.

Desta forma, a análise de dados se deu, basicamente, de forma qualitativa, ou seja, apoiando-se na análise do conteúdo dos dados e não em sua análise estatística. Para Cooper e Schindler (2003), os objetivos de uma pesquisa exploratória podem ser alcançados mediante o uso de diferentes técnicas, podendo ser aplicadas tanto as técnicas quantitativas como as qualitativas, reforçando que as qualitativas são mais confiáveis dentro de um estudo exploratório.

É preciso ressaltar que a pesquisa de campo deve respeitar o fato de que a análise do trabalho está intimamente relacionada ao próprio processo do trabalho, não sendo possível separá-los. Essa relação entre análise do trabalho e o próprio trabalho é reforçada na obra de Maggi (2006), afirmando-se que a análise é uma reflexão sobre o processo, sendo simultaneamente análise, mudança e formação. Assim, não é possível ao pesquisador, externo ao processo de trabalho, analisá-lo, sendo fundamental que os próprios trabalhadores participem da análise. 
As informações foram tratadas, classificadas e categorizadas, de acordo com seus significados, tendo como orientação o quadro 8, finalizado após análises e re-análises, idas e vindas e negações e afirmações dos aspectos fundamentais a serem discutidos. A partir do quadro, optou-se pela narrativa temática, organizando o texto extraído dos discursos com base no eixo do tema ou conceito do se queria revelar do discurso analisado, como definido na coluna "o que verificar" do quadro 8.

Quadro 8 - Categorias e Unidades de Análise

\begin{tabular}{|c|c|c|c|}
\hline $\begin{array}{c}\text { CATEGORIAS e Sub- } \\
\text { Categorias }\end{array}$ & $\begin{array}{l}\text { AUTORES } \\
\text { BASE }\end{array}$ & $\begin{array}{l}\text { O QUE VERIFICAR } \\
\text { Unidades de Análise }\end{array}$ & FONTES \\
\hline $\begin{array}{l}\text { CONCEPÇÃO } \\
\text { ORGANIZAÇÃO } \\
\text { - SISTEMA SOCIAL } \\
\text { PRÉ-DETERMINADO } \\
\text { EM RELAÇÃO AOS } \\
\text { SUJEITOS AGENTES } \\
\text { - SISTEMA SOCIAL } \\
\text { CONSTRUÍDO PELAS } \\
\text { INTERAÇÕES DOS } \\
\text { SUJEITOS } \\
\text { - AGIR SOCIAL- } \\
\text { PROCESSO DE } \\
\text { AÇÕES E DECISÕES }\end{array}$ & $\begin{array}{l}\text { Maggi } \\
(2006)\end{array}$ & $\begin{array}{l}\text { *Características principais de cada } \\
\text { concepção } \\
\text { *Natureza do processo de decisão } \\
\text { *Estrutura organizativa de ações e decisões } \\
\text { *Níveis de autonomia e discricionariedade }\end{array}$ & $\begin{array}{l}\text { - Pesquisa } \\
\text { bibliográfica } \\
\text {-Entrevista } \\
\text { em } \\
\text { profundidade } \\
\text { - Roteiro I e II }\end{array}$ \\
\hline $\begin{array}{l}\text { CONCEPÇÃO } \\
\text { FORMAÇÃO } \\
\text { - FORMAÇÃO NA } \\
\text { LÓGICA DO } \\
\text { SISTEMA: } \\
\text { MECANICISTA } \\
\text { ORGANICISTA } \\
\text { - FORMAÇÃO NA } \\
\text { LOGICA DO SISTEMA } \\
\text { CONSTRUÍDO: DO } \\
\text { ATOR } \\
\text { - FORMAÇÃO NA } \\
\text { PERSPECTIVA DO } \\
\text { AGIR - SISTEMA } \\
\text { COMO PROCESSO } \\
\text { DE AÇÕES E } \\
\text { DECISÕES } \\
\text { - CONSTRANGI- } \\
\text { MENTOS A } \\
\text { APRENDIZAGEM }\end{array}$ & $\begin{array}{l}\text { Kim (1998); } \\
\text { Kolb } \\
(1978 ; 1997 \\
\text { ); Garvin } \\
\text { (1993); } \\
\text { Senge } \\
\text { (1990); } \\
\text { Maggi } \\
\text { (2006, pag. } \\
\text { 203-206); } \\
\text { Nonaka e } \\
\text { Takeuchi } \\
\text { (1995). }\end{array}$ & $\begin{array}{l}\text { * Aprendizagem Individual } \\
\text { - Ausência de imposição da aprendizagem pelos } \\
\text { superiores. } \\
\text { - Respeito ao tempo e ao jeito de cada sujeito durante a } \\
\text { aprendizagem. } \\
\text { - Conhecimento do porquê e para quê aprender. } \\
\text { - Ausência de restrições e preconceitos a respeito de } \\
\text { novas experiências. } \\
\text { - Disponibilidade para refletir sobre as experiências. } \\
\text { - Apoio de pessoas que não participaram diretamente da } \\
\text { experiência. } \\
\text { - Processo de feedback constante. } \\
\text { - Acesso a teorias a respeito da experiência. } \\
\text { - Autonomia para realizar novas experiências. } \\
\text { * Aprendizagem Organizacional } \\
\text { - Flexibilidade na comunicação. } \\
\text { - Reflexão coletiva sobre as experiências. } \\
\text { - Possibilidade de observar o trabalho dos demais. } \\
\text { - Todos os sujeitos em processo de aprendizagem } \\
\text { individual. } \\
\text { - Constante interação entre os sujeitos. } \\
\text { - Atividades amplas que lidam com imprevistos. } \\
\text { - Autonomia para os sujeitos resolverem os } \\
\text { imprevistos. } \\
\text { - Vivência de circunstâncias incertas e quebras de } \\
\text { rotina. } \\
\text { - Redundância de informação. } \\
\text { * Quadro hipotético } 18\end{array}$ & $\begin{array}{l}\text { - Pesquisa } \\
\text { bibliográfica } \\
\text { - Entrevista } \\
\text { em } \\
\text { profundidade } \\
\text { - Roteiro II } \\
\text { parte B e C }\end{array}$ \\
\hline
\end{tabular}


Continuação Quadro 8 - Categorias e Unidades de Análise

\begin{tabular}{|c|c|c|c|}
\hline \begin{tabular}{lr}
\multicolumn{2}{l}{ CONSEQUÉNCIAS } \\
SOBRE & O \\
PROCESSO & DE \\
FORMAĈ̃O & E \\
APRENDIZAGEM & \\
$-\quad$ NECESSIDADE & E \\
ANÁLISE & DAS \\
NECESSIDADES & \\
- RESULTADO & E \\
AVALIAÇÃO & DOS \\
RESULTADOS & \\
$-\quad$ PLANIFICAÇÃO & E \\
PROJETOS & \\
- ATIVIDADES & E \\
SUJEITOS & DA \\
FORMAÇÃO &
\end{tabular} & $\begin{array}{l}\text { Maggi } \\
(2006)\end{array}$ & $\begin{array}{l}\text { * Planejamento } \\
\text { * Resultados } \\
\text { * Contingências }\end{array}$ & $\begin{array}{l}\text { - Entrevista } \\
\text { em } \\
\text { profundidade } \\
\text { - Pesquisa } \\
\text { bibliográfica } \\
\text { - Roteiro II }\end{array}$ \\
\hline
\end{tabular}

Fonte: a autora.

Para a validação do estudo, Yin (2001, p.55-56) recomenda quatro testes: validade de construto, validade interna, validade externa e confiabilidade. Pensando na validade interna, embora seja mais utilizada e necessária para estudos de caso causais ou explanatórios, foram utilizados protocolos (quadros 5 e 6) para o desenvolvimento, orientação e formalização do estudo de caso e de uma base bibliográfica consistente, que suportou as conclusões e discussões da pesquisa; pensando na validade de construto, trabalhou-se com diversas fontes de dados, pesquisa teórica, entrevista em profundidade e análise documental, objetivando triangular dados e alcançar diversas evidências para as conclusões. Pensando na validade externa, por ser um estudo de caso único, as conclusões ficam circunscritas à organização pesquisada; contudo, a partir da discussão dos dados empíricos, em conjunto com a discussão teórica, oriunda de realidades diversas, observa-se uma aplicabilidade consideravelmente ampla das conclusões encontradas. Pensando na confiabilidade do estudo, procurou-se estabelecer etapas bastante claras e sistematicamente operacionalizadas para que seja possível reconduzir o estudo, seguindo os mesmos passos e chegando às mesmas conclusões. 


\subsection{3) Limitações do Estudo}

Inicialmente, cabe ressaltar que não existe método perfeito, pois todos apresentam uma dimensão subjetiva (MARTINS, 2006) e que a crítica freqüente de que os estudos de caso impedem generalizações foram percebidos pela pesquisadora como uma grande oportunidade de aprofundamento do assunto na organização pesquisada e conseqüente detalhamento de aspectos que não poderiam ser analisados por meio de métodos quantitativos.

A interpretação conjunta dos conceitos aprendizagem e constrangimento devem ser citados como um dos principais desafios desta pesquisa, que carece de aprimoramentos em termos de novos instrumentos de coleta de dados, análises estatísticas comprobatórias das análises exploratórias, enfim, este estudo embrionário deve ser continuado e explorado em suas várias perspectivas descobertas.

No tocante às críticas relacionadas à pesquisa qualitativa como um todo, foram adotados diversos cuidados metodológicos para garantir a cientificidade, minimizando assim as influências da percepção do pesquisador e possibilitando o retrato fiel acerca dos dados coletados. Portanto, esta pesquisa buscou maior segurança nas conclusões através da categorização dos elementos de análise - sustentada na base teórica - e não espera que seus resultados sejam generalizados ou extrapolados para situações nãosemelhantes.

Outra limitação do estudo advém da proposta de melhor compreender a triangulação aprendizagem, concepções organizacionais e constrangimentos, considerada pouco explorada, complexa e ampla em suas possibilidades de estudo e definição conceitual. Isto pode ter contribuído para a existência de pontos sem a atenção necessária. Contudo, a presente tese não tem como objetivo principal ser exaustiva em suas conclusões, mas sim abrir caminhos e lançar questionamentos. Ressalta-se, também, que estudos qualitativos estão em permanente construção; às idas e vindas, a criação e a recriação estão presentes em todas as fases do trabalho. Por outro lado, a profundidade alcançada em estudos qualitativos permite encontrar informações 
amiúde sobre os temas em estudo, o que dificilmente um survey conseguiria. Conforme o desenrolar das entrevistas, cada vez mais, profundidade e confirmação dos dados são possíveis, pois o aumento do conhecimento da pesquisadora sobre a realidade em análise limita as possibilidades de "maquiagem" da mesma por parte dos entrevistados. 


\section{INTERPRETAÇÃO E ANÁLISE DOS DADOS}

Neste capítulo será apresentada a organização na qual se desenvolveu a pesquisa de campo, incluindo informações a respeito de sua estrutura organizacional, área de atuação, norteadores do desenvolvimento organizacional e o porquê de sua escolha.

A seguir, discorre-se sobre os resultados da pesquisa por meio da análise e discussão relacionadas às seqüências expostas nos quadros 5 e 6.

\section{1) Apresentação da Organização}

O Hospital Universitário (HU) é um Órgão Suplementar da Universidade Estadual de Londrina-UEL (Autarquia Estadual), vinculado administrativamente à Reitoria da Universidade e academicamente ao Centro de Ciências da Saúde, foi implantado como Hospital-Escola em 24/03/1970. Tem como missão "Prestar assistência integral à saúde, com excelência e qualidade, participando na prática do ensino, pesquisa e extensão, perfeitamente integrado ao Sistema Único de Saúde, contribuindo para a melhoria da qualidade de vida da população."

Tem como objetivos principais: desenvolver o ensino, a pesquisa e a extensão de serviços à comunidade, através da prestação de assistência à saúde da população em caráter universal, abrangendo todas as especialidades médicas. É o único hospital público de grande porte no Norte do Paraná. Constituindo-se em um Centro de Referência Regional para o Sistema Único de Saúde (SUS), tendo como finalidade precípua o desenvolvimento das seguintes ações: Formação de Recursos Humanos; Educação continuada; Pesquisa e desenvolvimento tecnológico; Cooperação técnica e científica com a rede de serviços; Assistência à saúde da população, atuando como interface natural entre o sistema formador e a comunidade. 
O volume de serviços desenvolvido pelo HU é significativo, sendo que em 2007 foram realizados os seguintes serviços: 138.752 atendimentos ambulatoriais, 50.959 atendimentos de pronto-socorro, 10.881 internações, 6.265 cirurgias, 704.998 exames de análises clínicas, 47.511 exames de radio/imagem, dentre outros. Integra diversos Sistemas de Alta Complexidade do SUS, entre os quais se destacam: Transplante Renal, Transplante de Córneas, Oncologia, Ortopedia, Neurocirurgia, Videolaparoscopia, Implante de Marca-Passo Definitivo, AIDS, Busca Ativa e Abordagem de Possível Doador de Órgãos para Transplantes, Cirurgia Bariátrica (Gastroplastia), Esterilização (Planejamento Familiar), Unidade de Terapia Intensiva e Assistência a Queimados.

Em 14/06/2000 recebeu o título de "Centro Colaborador para a Qualidade da Gestão e Assistência Hospitalar" outorgado pelo Ministro da Saúde, considerando a seleção realizada pela Secretaria de Assistência à Saúde - Portaria GM/MS no 593/2000, de 20/06/2000. Em 14/09/2000 recebeu o título "Hospital Amigo da Criança" outorgado pelo UNICEF - Fundo das Nações Unidas para a Infância e Organização Mundial de Saúde, através do Ministério da Saúde. O HU é o 14ํㅜ Hospital-Escola do País a receber o título. Em 18/04/2001 recebeu o prêmio "Qualidade Hospitalar 2000" outorgado pelo Ministério da Saúde às instituições que se destacaram pela qualidade da assistência prestada aos pacientes do SUS, segundo avaliação dos próprios pacientes. Em 04/07/2001 - Portaria MS 1006 - o HU é qualificado como Hospital Estratégico do Ministério da Saúde.

O HU conta com uma equipe multiprofissional altamente qualificada em diversas áreas de atuação, compreendendo 80 cargos no total, buscando oferecer aos pacientes atendidos pelo mesmo, os melhores serviços técnicos, consoantes com as políticas de saúde e humanização do Ministério da Saúde. Além de sua atuação no campo assistencial, são desenvolvidos no HU diversos cursos de graduação e pós-graduação. Vide organogramas anexo. 


\section{2) Justificativa da Escolha do Hospital como objeto de estudo e da Diretoria de Enfermagem e sua Breve Descrição}

Para a realização deste estudo, foi escolhida esta organização, principalmente, por seu rico campo de pesquisa, possibilidades de explorar muitos conhecimentos e áreas distintas. Um espaço onde é necessária uma aprendizagem de alto nível para a realização de suas atividades e também de desenvolvimento das ações e decisões, mas que tem muito presente, no seu dia-a-dia, os constrangimentos, que é um dos focos de discussão desta pesquisa.

Desde o início, o foco era uma organização de médio porte, que proporcionasse espaço para as discussões do estudo. Através de alguns conhecidos, tive fácil acesso ao hospital, o que facilitou a escolha da organização.

Como o hospital é muito grande e complexo, foi escolhida a diretoria de enfermagem, o maior setor do hospital, para a realização das entrevistas, também de forma aleatória, escolhendo os enfermeiros de acordo com a sua disponibilidade.

Cabe destacar que o $\mathrm{HU}$ tem obtido reconhecimento nacional decorrente de suas ações e atuações em praticamente todas as especialidades médicas. O reconhecimento também tem vindo do usuário, que pelas pesquisas de satisfação registra sua opinião favorável à Instituição. Outra consideração é a de que a missão do HU o inclui como hospital-escola, portanto participa na prática do ensino, da pesquisa e da extensão, integrado ao SUS. Serve de campo de estágio direto para os cursos de graduação em Medicina, Farmácia-Bioquímica, Enfermagem e Fisioterapia, além de programas de estágio de outras áreas, como Serviço Social e Administração. Oferece Residência Médica em mais de 30 especialidades e Residência em Fisioterapia em duas áreas, além de outros cursos de pós-graduação stricto e lato sensu. 
Destaca-se também a estrutura dos grandes investimentos realizados pela organização na área de Treinamento e Desenvolvimento, além da implantação, com êxito, de um programa que vincula a remuneração de seus colaboradores à avaliação de desempenho individual realizada periodicamente pelos gestores das respectivas áreas. E, por último, a organização se mostrou extremamente favorável à realização deste estudo e se colocou como parceira em todas as suas etapas.

A diretoria de enfermagem, maior diretoria do hospital e que lida diretamente com o conceito de "prestação de serviços" tanto como fornecedora quanto como receptora de diversos serviços do hospital. Atenta à complexidade de sua atuação, busca a aproximação entre os seus interesses e os desejos dos funcionários, para o alcance de suas metas e objetivos que são pautados na busca de sua continuidade e na imagem positiva que deseja manter para a sociedade. Portanto, é imprescindível a realização de um trabalho continuo junto aos funcionários para integrá-los à diretoria e desenvolvê-los profissionalmente e pessoalmente.

O desenvolvimento dos profissionais tem sido reforçado pelas atuais e constantes mudanças e transformações que estão ocorrendo no mundo do trabalho. Essas mudanças ocorrem rapidamente devido a facilidade de acesso as informações, em conseqüência do avanço tecnológico e das profundas modificações sócio-econômicas. Essas transformações, também agregaram novos desafios ao comportamento dos funcionários frente aos objetivos e metas da organização, bem com da organização diante dos anseios dos funcionários. Para alcançar as necessidades individuais e organizacionais, a tríade ação - reflexão - ação, é essencial quando se trata de mudanças, que é um processo demorado que depende do indivíduo e da sua da capacidade de aprendizagem.

Neste contexto, o $\mathrm{HU}$, especificamente, a diretoria de enfermagem (DE), busca se inserir neste processo de mudanças e desenvolvimento de pessoal, através da modernização administrativa e do aprimoramento da gestão de pessoal. Assim, os serviços de educação continuada têm um papel de destaque na diretoria, uma vez que permeiam todo o processo de formação 
do profissional através de treinamentos específicos nas áreas de desenvolvimento pessoal, gerencial, técnico-científico e especializado, visando melhorar a qualidade de assistência prestada aos indivíduos doentes. Portanto, a educação continuada tem como desafio estimular 0 profissional a desenvolver uma consciência crítica, ajudando-o a atuar de forma mais efetiva e eficaz.

Desta maneira 0 treinamento tem por finalidade dar complementação educacional ao funcionário de modo a integrá-lo às metodologias e técnicas de trabalho utilizadas na instituição. A educação e treinamento são formas de desenvolver os indivíduos, isto é, de impulsionar o homem a gerar mais idéias, a aprimorar os sentidos, a obter mais emoção e adquirir maiores habilidades. Entende-se, na DE, que a educação tem um caráter contínuo e se confunde com a própria vida, portanto o querer aprender das pessoas deve estar sempre presente ou latente, necessitando ser estimulado e lapidado.

Os serviços de educação continuada, de treinamento ou desenvolvimento do HU têm como desafio estimular o adulto a crescer como indivíduo, a ser feliz, a buscar mais qualidade e satisfação na sua vida, de modo que o reflexo positivo deste desenvolvimento possa ser verificado pela melhoria da qualidade da assistência que presta ao cliente.

A partir de uma concepção adotada, as organizações, independente de sua natureza, têm que ter metas ou diretrizes que enfoquem como principal objetivo o desenvolvimento pessoal e profissional de seus funcionários. Somente a partir de então, ações podem ser planejadas e executadas para o alcance desses objetivos.

Neste contexto, foi escolhida a Diretoria de Enfermagem do Hospital Universitário de Londrina, que possui um grande número de funcionários(em torno de 500) envolvidos diretamente com a complexidade apresentada por este trabalho e, por ter um departamento específico de treinamento, a DEPE Divisão de Educação Continuada e Pesquisa, que planeja suas atividades baseada na política de desenvolvimento de pessoal do $\mathrm{HU}$ e nas diretrizes da DE - Diretoria de Enfermagem. 
Em relação à diretoria de enfermagem, se levantou as seguintes diretrizes:

- Estimular o comprometimento do servidor da equipe de enfermagem com o seu desenvolvimento pessoal e profissional.

- Garantir a qualidade da assistência de enfermagem, prestando atendimento seguro.

- Implementar os padrões de qualidade e os critérios de avaliação da assistência de enfermagem, propostos pela Assessoria de Controle de Qualidades da Assistência de enfermagem - ACQAE.

Em relação aos treinamentos para cumprir estas diretrizes a "DEPE", organiza suas atividades através do "Levantamento da Necessidade de Treinamento - LNT", que é realizado junto a D.E, Chefias de Divisão e funcionários, além dos dados contidos nos relatórios emitidos pela "Assessoria de Enfermagem no Planejamento e Controle - AEPC", "Assessoria de Controle da Qualidade da Assistência de Enfermagem - ACQAE", pela "Comissão de Controle de Infecção Hospitalar - CCIH", pela "vigilância sanitária", entre outros.

A partir deste levantamento, os treinamentos/cursos são organizados pelas áreas de abrangência que se segue:

- Desenvolvimento Pessoal - DP,

- Desenvolvimento Gerencial - DG,

- Desenvolvimento Técnico-Científico - DTC,

- Desenvolvimento Técnico-Científico Especializado-DTCE.

A DEPE preza pelo desenvolvimento pessoal e profissional dos funcionários da Diretoria de Enfermagem. Também estimula todos os membros da equipe de enfermagem e principalmente os enfermeiros especialistas a multiplicarem os conhecimentos adquiridos, possibilitando que esses profissionais busquem com afinco o aprimoramento dos processos de trabalho, revertendo suas ações em uma assistência de enfermagem com excelente qualidade aos pacientes.

Tem como obje tivos:

- Conscientizar o enfermeiro sobre a sua função de educador, visando a melhoria da qualidade da assistência.

- Estimular o desenvolvimento de indivíduos participativos. 
- Desenvolver o potencial crítico-criativo do pessoal da equipe de enfermagem e possibilitar novos conhecimentos para melhorar as habilidades já existentes.

- Aperfeiçoar os processos de capacitação possibilitando o melhor aproveitamento de recursos humanos da enfermagem.

- Desenvolver tecnologias próprias da enfermagem fundamentadas no ensino e na prática.

- Atuar em parceria com a Diretoria de Enfermagem, Assessoria de controle de qualidade da assistência de enfermagem, Assessoria de controle de recursos materiais, Assessoria do planejamento de enfermagem e Divisões de enfermagem, avaliando continuamente os processos de ensino aprendizagem para a melhoria da qualidade da assistência prestada aos pacientes.

- Estabelecer normas técnicas para todo o pessoal de enfermagem.

Seu (DEPE) trabalho abrange principalmente os funcionários da Diretoria de Enfermagem do HU, bem como funcionários das demais diretorias, alunos e funcionários da UEL. A educação continuada dos funcionários da instituição não é função única e exclusiva desta Divisão, é exercida por todos aqueles que têm responsabilidade de supervisão e chefia. Neste sentido, a DEPE adotou o SISTEMA MISTO de funcionamento, onde as atividades de Educação Continuada são realizadas pela equipe de trabalho da DEPE e pelos profissionais especializados das unidades de trabalho.

A comunicação entre a DEPE e os outros setores ocorre para que haja uma relação segura e completa atingindo assim todos os seus objetivos. Portanto, conta com um sistema de comunicação, onde todas as informações estão centralizadas, organizadas, acessíveis e atualizadas, fornecendo assim subsídios para soluções de problemas ou renovação de conhecimentos.

As atividades são:

- divulgação dos eventos e treinamento.

- registros computadorizados dos treinamentos/cursos bem como do no de participantes, carga horária, período, horário, nome e categoria funcional e nome do instrutor.

- emissão e registros de certificados para os coordenadores, instrutores e participantes, contendo os seguintes dados: o nome do curso/treinamento, a carga horária, o período, o local de realização, o nome do promotor e o programa, $n^{\circ}$ de registro, folha e $n^{\circ}$ do livro de registro. 
- relatórios mensal de treinamentos (Anexo I) onde são registrados os cursos promovidos pela DEPE.

- relatórios mensal de eventos (Anexo II) onde são registrados as participações em simpósios, congressos, encontros, visita técnica entre outros, cujos eventos não foram promovidos pela DEPE.

- relatórios mensais dos participantes em treinamentos por Divisão e suas unidades (Anexo III).

- relatório anual (Anexo IV).

- livro de controle dos certificados emitidos.

- livros protocolos de retirada de material bibliográficos, e outros.

O DEPE apresenta também claramente definidas as competências para quem lá atuar. São elas:

- Planejar e elaborar programas de treinamento conforme 0 levantamento das necessidades de desenvolvimento.

- Cooperar com a adaptação do funcionário recém admitido ao novo ambiente de trabalho.

- Preparar tecnicamente a equipe de enfermagem para executar as funções que lhe são atribuídas.

- Elaborar manuais de procedimentos técnicos e administrativos.

- Produzir material didático pedagógico tais como recursos audiovisuais, apostilas, folders de orientação, entre outros.

- Manter contato permanente com os chefes de divisão e seção para planejamento de cursos, treinamentos e estágios.

- Participar dos processos de recrutamento, seleção e movimentação de pessoal;

- Colaborar na implementação de metodologia de assistência de enfermagem.

- Constituir, presidir e participar de grupos e comissões.

- Acompanhar visitas internas e externas.

- Participar no processo de seleção de candidatos a cargos nas diversas categorias de enfermagem.

- Colaborar e realizar pesquisa na área de enfermagem e áreas afins.

- Participar no planejamento e atualização de normas e rotinas de enfermagem.

- Fazer reuniões periódicas com os enfermeiros para avaliação das atividades desenvolvidas.

- Participar de reuniões de serviço.

- Providenciar material didático para realização dos cursos.

- Divulgar atividades, normas, técnicas e rotinas.

- Propiciar a atualização do funcionário, para melhorar e ampliar seus conhecimentos do seu campo específico de ação e possibilitar a manutenção de padrões de trabalho condizente com a evolução da atualidade. 
- Avaliar e acompanhar o aproveitamento dos participantes dos treinamentos.

- Avaliar os recursos didáticos utilizados nos cursos, visando a elevação da qualidade do serviço.

- Elaborar relatórios mensais sobre os cursos e eventos realizados, número de horas treinadas e categoria profissional treinada.

- Estimular o enfermeiro a desenvolver o papel de educador e participar dos grupos e comissões.

- Emitir parecer sobre as avaliações dos treinamentos realizados.

- Elaborar prova para concurso público / seleção.

- Participar da seleção e do recrutamento do candidato para treinamento.

- Promover processo seletivo para estágios administrativos extracurriculares para alunos de Graduação em Enfermagem e de outras áreas afins / residência.

- Planejar e monitorar as atividades dos estagiários, junto as Chefes de Divisão e Seção.

- Elaborar programas dos cursos e treinamentos para a emissão de certificado.

- Promover eventos externos.

Na DEPE também são realizadas atividades específicas das seguintes áreas básicas: avaliação de desempenho, aperfeiçoamento, treinamento, seleção e movimentação, cujas descrições seguem a seguir:

\section{AVALIAÇÃO DE DESEMPENHO}

- acompanhar o desenvolvimento do recém admitido através da emissão de relatório técnico de desempenho no treinamento.

- acompanhamento individual do aprendizado do servidor após o término do treinamento.

\section{APERFEIÇOAMENTO}

- controlar e acompanhar visitas e estágios;

- implantar normas, rotinas e procedimentos;

- promover treinamentos específicos para servidores com déficit de desempenho;

- promover treinamento e atualização para toda equipe de enfermagem;

- possibilitar a participação dos funcionários em eventos científicos e visitas técnicas à empresas locais e de outras localidades.

\section{TREINAMENTO}

- treinar os funcionários nos casos de alteração de função; 
- treinar funcionários recém admitidos;

\section{SELEÇÃO E MOVIMENTAÇÃO}

- emitir parecer do desempenho do servidor no treinamento admissional;

- emitir parecer técnico sobre o desempenho do funcionário recémadmitido nos treinamentos, podendo o mesmo ser utilizado para 0 desligamento de pessoal;

- sugerir unidade mais adequada ao perfil do funcionário;

- promover concurso público conforme demandas de vagas

- estabelecer critério para seleção e contratação do servidos;

- estabelecer critérios para avaliação do curriculum vitae;

- elaborar prova;

- Determinar comissão de seleção de concurso público.

\section{3) Orientações Para a Definição de Treinamentos e Aperfeiçoamento de}

\section{Pessoal}

A DEPE da DE tem como fundamental que a instituição esteja preocupada em manter seus funcionários atualizados e em contínuo desenvolvimento, oferecendo e incentivando a participação em cursos e eventos com a finalidade de formar indivíduos mais capacitados e interessados.

Neste sentido, a primeira etapa para a elaboração do Programa anual de Desenvolvimento é o Levantamento das Necessidades de Desenvolvimento LND de cada setor da instituição. Após este levantamento são estabelecidas as possíveis estratégias pedagógicas, entre elas estão:

- preleção,

- visita técnicas a outras instituições,

- observação da realidade,

- demonstração de procedimento,

- participação em cursos, seminários, congressos, encontros científicos, workshop e outros,

- estudo de caso.

A partir do LND, é elaborado o Programa Anual de Desenvolvimento (Anexo V), onde são considerados os objetivos e as variáveis que se seguem: 
- formação de multiplicadores;

- atualização ou aperfeiçoamento em conhecimentos básicos ou especializados.

- a unidade ou setor solicitante e número de funcionário a ser treinado;

- turno de trabalho dos interessados associado com o horário proposto para o treinamento;

- a carga horária;

- a escolha do instrutor podendo este ser da própria equipe de enfermagem ou outros profissionais;

- necessidade ou não de recursos financeiros,

- disponibilidade de sala de aula;

- tempo hábil para divulgação e outros.

Abaixo, elaborou-se esquemas, a partir dos dados coletados, para demonstrar os fluxos tomados para a definição do que e como será treinado.

Figura 5 - PROCESSO DE DIAGNÓSTICO DO DESENVOLVIMENTO DE PESSOAL

LND - Levantamento da necessidade de desenvolvimento

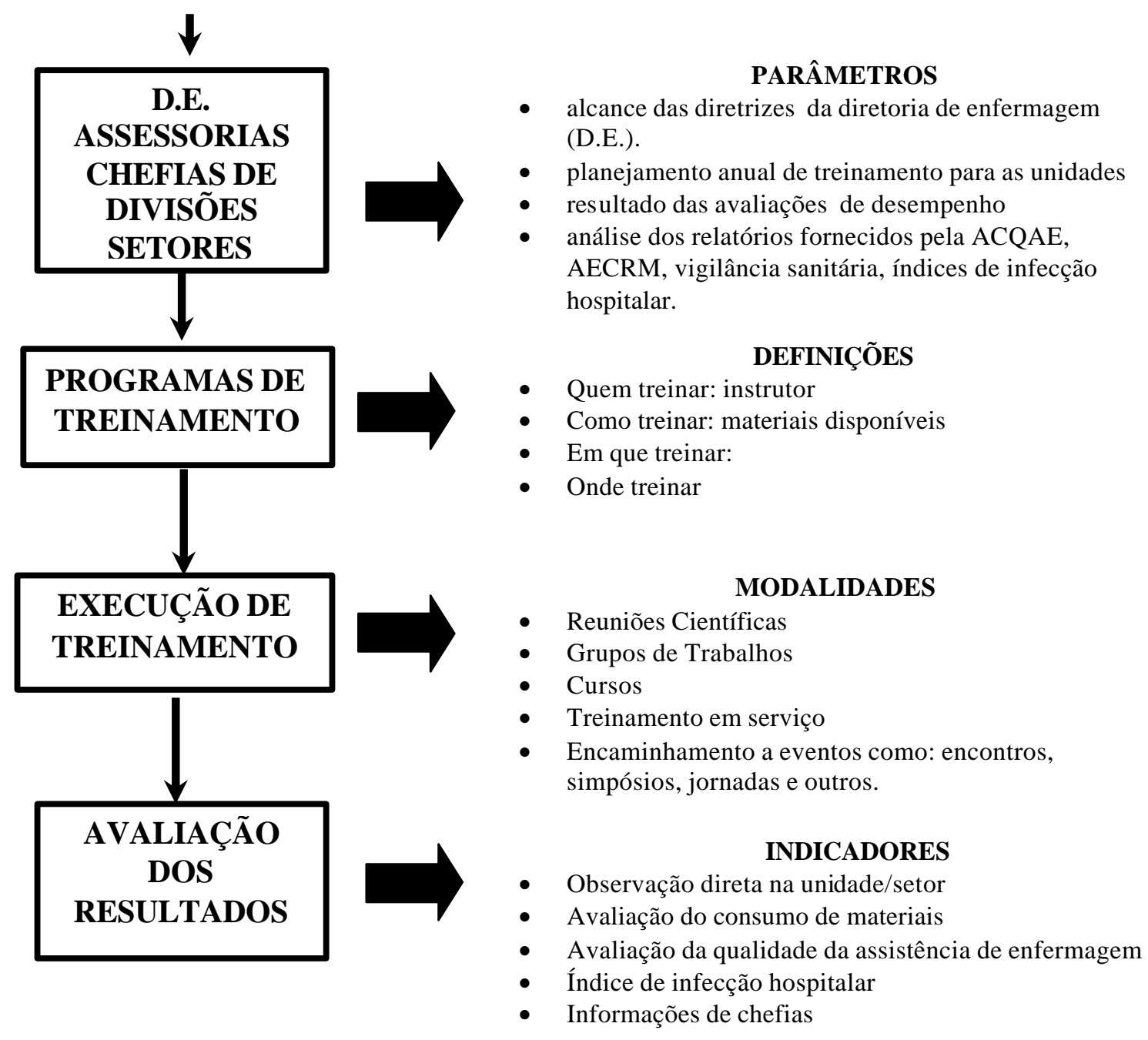


Figura 6 - ESQUEMA SIMPLIFICADO PARA A ELABORAÇÃO DE CURSO/TREINAMENTO
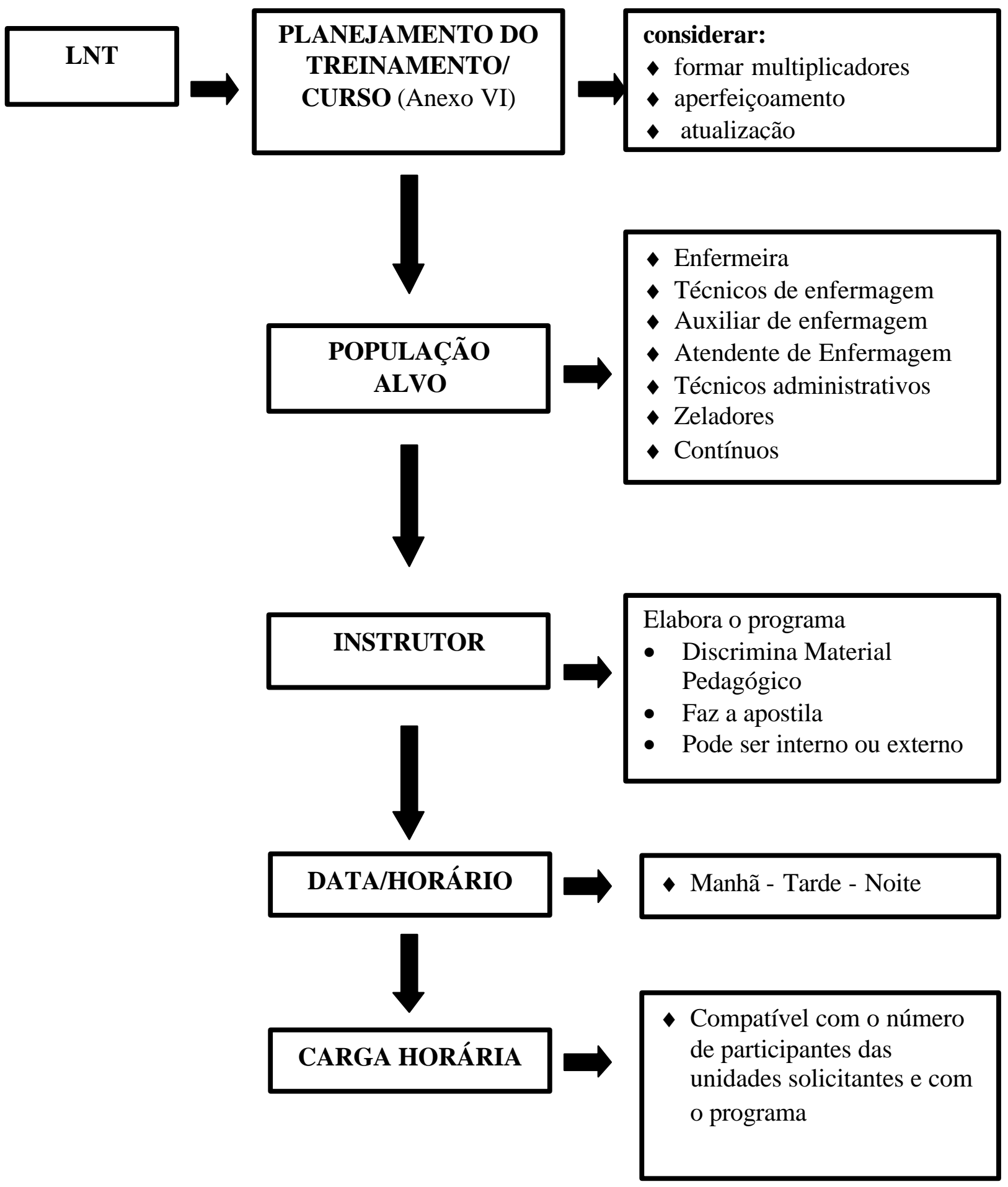

- Enfermeira

- Técnicos de enfermagem

- Auxiliar de enfermagem

- Atendente de Enfermagem

- Técnicos administrativos

- Zeladores

- Contínuos

Discrimina Material

- Faz a apostila

- Pode ser interno ou externo de participantes das unidades solicitantes e com o programa 
Figura 7 - ESQUEMA COMPLEXO PARA A ELABORAÇÃO DE CURSOS/TREINAMENTO

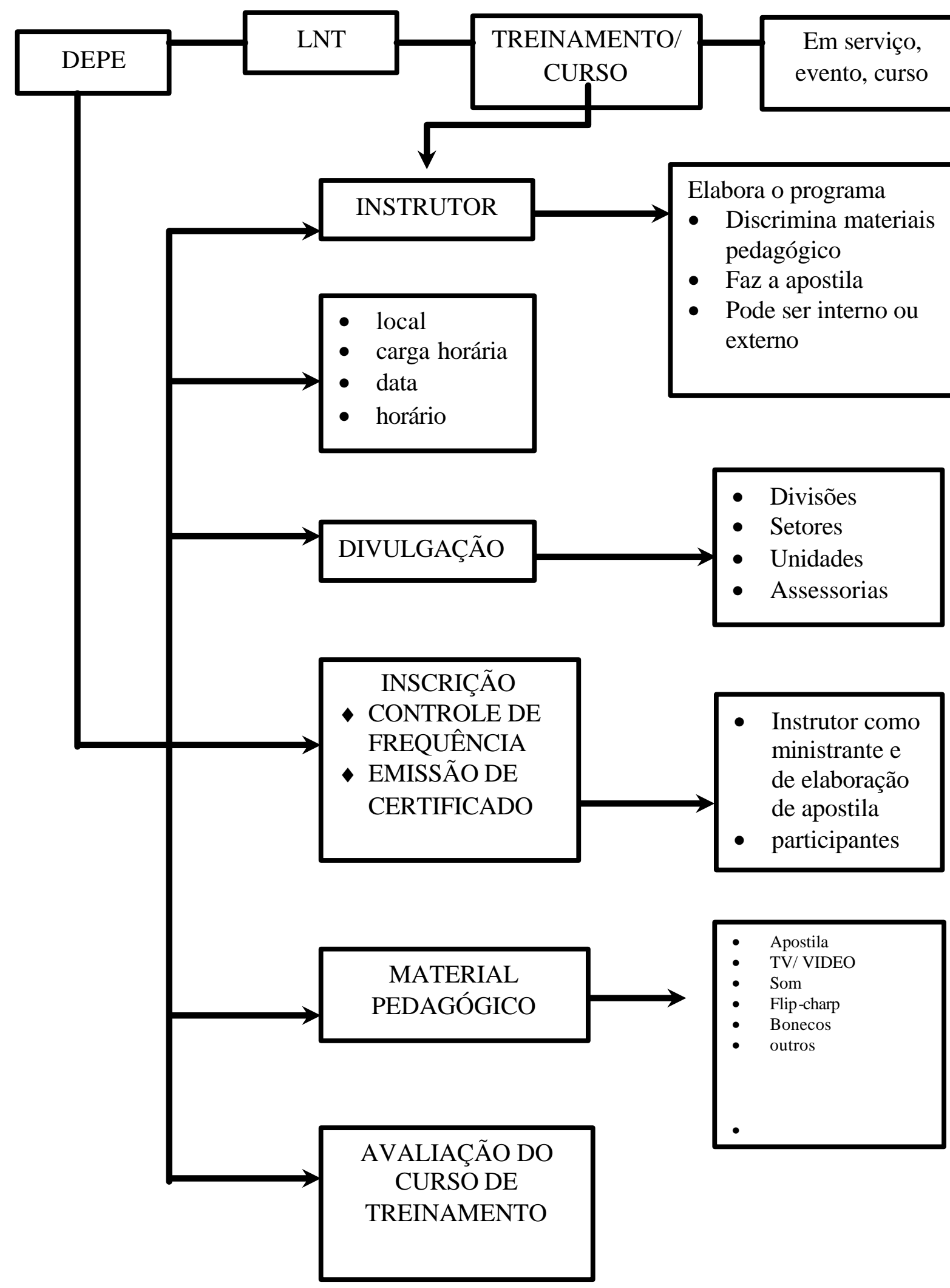




\subsection{1) Programa De Treinamento Para Funcionário Recém-Admitido}

Os programas de treinamentos para funcionários recém admitidos são realizados gradativamente, evitando a sobrecarga de informações em curto período de tempo, dificultando assim o aprendizado do funcionário. Em relação a composição do programa para funcionários recém-admitidos, são fornecidas as orientações que se seguem:

- Gerais: trata-se de um conteúdo informativo e generalizado a ser ministrado a todos os funcionários. Consta de duas fases: Imediata: de conteúdo mínimo necessário para tornar o funcionário apto a entrar na unidade. Mediata: conteúdo relativo à instituição e as atividades peculiares da enfermagem da instituição.

- Orientações específicas: informações específicas de cada unidade de trabalho. Reconhecimento da unidade: relacionadas as rotinas do local como passagem de plantão, escala diária e mensal, planta física, equipamentos e materiais, localização dos medicamentos; Conhecimentos de normas e rotinas;Metodologia da assistência de enfermagem.

O funcionário convocado após a aprovação no concurso público é encaminhado pela $\mathrm{CRH}$ - Coordenadoria de Recursos Humanos e sua trajetória até a contratação está demonstrada no Fluxograma de recepção do funcionário da enfermagem recém-admitido.

\subsection{2) Apresentação e Análise das Entrevistas}

Como são construídos os processos de cooperação e coordenação em relação ao tempo (estabilidade/mutabilidade) e à forma (homogeneidade/heterogeneidade)?

E em relação à coordenação das ações técnicas e à coordenação das ações para o desenvolvimento de ações? (tendo em vista a formação) 
A coordenação e cooperação das ações acontecem de maneiras bastante próximas na realidade pesquisada. Todos estão cientes das limitações em termos de recursos, contudo, prezam pela missão "institucionalizada" de prestação de assistência ao paciente. Demonstram estar isto, acima de tudo na organização.

Uma evidência da estabilidade dos processos cooperativos é que $100 \%$ dos respondentes afirmam que um novo profissional que assuma seus lugares levará no, máximo, um mês para trabalharem no mesmo nível que eles. Evidenciando um roteiro bem definido, contudo, não escrito, da execução das atividades. Como salienta o entrevistado 11 "independente do tempo que a pessoa está aqui na instituição, rapidinho ela pega o jeito do trabalho".

As necessidades de formação, geralmente surgem por causa de problemas detectados por determinados setores. Os supervisores são responsáveis pela coordenação da integração e harmonia dos grupos de trabalho, contudo, têm forte limitação de tempo para isso. Segundo 16 dos 20 entrevistados "fazem o possível". Para coordenar a escala de trabalho, muitas vezes, citado por cinco entrevistados, há um "abuso" dos funcionários temporários. Como salientam dois deles (E12; E4; E19 respectivamente) "Às vezes mudam o nosso horário sem se preocupar que nós também temos família e não podemos estar toda hora a disposição. Existe um abuso dos "crês" (temporários) para fazer as tarefas mais chatas e tampar muitos buracos ... As coisas são impostas". "Trocamos idéias sim, mas não freqüentemente. A palavra dos estatutários tem mais peso na opinião".

Os processos de coordenação e cooperação se repetem, ou seja, o tempo não é uma variável preponderante na coordenação das ações e a forma segue os padrões estabelecidos pelo departamento de treinamento e pesquisa. Embora este, tente variá-los conforme salienta o entrevistado E10: que comprar a causa, acreditar no treinamento." 
Observou-se grande preocupação dos supervisores com as motivações, mas não sempre por falta de tempo. Quando há momentos de encontros, estão sempre juntos, buscando a motivação. Há na organização o planejamento das atividades, o que foi citado por $60 \%$ dos entrevistados, contudo, sempre acontecem os imprevistos. Exemplo falta material e tempo para tomar decisões, daí cada um resolve como entende melhor. Como salienta E13 "Falta de tudo! Estamos vivendo uma situação difícil. Nunca tivemos falta de material como agora. Precisamos nos preocupar como vamos fazer para atender o nosso paciente sem prejudicá-lo". O que ficou evidente é que os enfermeiros que trabalham na assistência direta ao paciente, têm espaços discricionários mais amplos que os da administração. Entre a vida e a morte, podem fazer o que quiser dentro da heteronomia do processo. Como salienta E2, "Sim, meu supervisor coordena a integração, mas temos que prestar muita atenção no que estamos fazendo, pois muita coisa foge ao "coordenado". E4 reforça "precisamos mais auto-crítica, o que você representa no seu papel, temos dificuldades de seguir um planejamento, isto dificulta o desenvolvimento das nossas atividades".

Contudo, salientaram $50 \%$ dos entrevistados, resumido nas palavras do E3 "na insegurança de tomar uma decisão frente ás incertezas é melhor tirar uma opinião com um colega de serviço. A responsabilidade é muito alta." O que demonstra formas de coordenação das ações próprias, sem intervenção de supervisores, mesmo porque, em grande parte das vezes estão ocupados, como já salientado. Como reforça E9 "a comunicação poderia ser melhor intra e entre as áreas, pois são os supervisores e a diretoria que articulam os aprendizados".

$40 \%$ dos entrevistados afirmaram não participar muito de diálogos com os colegas. É uma deficiência. Segundo E3 "precisaríamos mais reuniões para conversar sobre estes assuntos. Já foi passado para a chefia a necessidade de ter mais reuniões". Ainda reforça "as unidades pecam em fazer a integração entre todos os profissionais, deixar com que cada um expresse sua necessidade, apesar de todos se empenharem, falta tempo para todos estarem juntos, às vezes nos resolvemos questões importantes no corredor. Às vezes, literalmente, como no caso do atendimento pronto-socorro". 
Outro elemento articulador de ações, citado por $100 \%$ dos entrevistados, é a necessidade de respeitar interesses políticos, a boa relação e articulação das ações passam por não confrontar o poder, mesmo estando certo, abre-se mão da posição para evitar o conflito. Como salienta E10 "eu que gosto de dar satisfação das coisas que estou fazendo". Embora muitos o façam, no caso de privilegiar o paciente, o que é respeitado mesmo pelo poder instituído, aliás, o bem-estar do paciente é uma instituição per si.

Autonomia, comunicação, decisão e discricionariedade. Como os sujeitos dominam o processo de trabalho?

Oitenta por cento dos entrevistados afirmaram ter autonomia no processo de trabalho, contudo, como salienta Maggi (2006) autonomia é possibilidade de criar rumos próprios sem impedimentos, aqui percebe-se que se faz válido diferenciar autonomia e discricionariedade. Pois o que se verificou foi a existência desta. Como salienta o entrevistado 3 "dependendo da situação [...] tenho recursos para tomar decisões". E1 afirma que "devido a quantidade de pacientes é muito difícil conversar com os colegas, ficando a comunicação restrita ao já ente ndido".

Em relação ao valor do paciente para os enfermeiros, ressalta e1 'Eu faço o contrário, realizo o meu trabalho pensando primeiro no paciente, depois no meu supervisor". Como a enfermagem lida praticamente com todos os demais setores do hospital (farmácia, nutrição, médicos, manutenção, etc.) e deles dependem, os enfermeiros administradores, devem ter a habilidade de se comunicar muito desenvolvida, contudo, não é bem o que acontece. A comunicação foi citada por $90 \%$ dos entrevistados com um dos principais empecilhos ao aprimoramento das ações, muitos perdem muito tempo negociando com as demais áreas para conseguir o que é preciso, além disso ainda há a dificuldade na própria área de enfermagem, unidades que dependem uma da outra e não se entendem, competem entre si. Como salienta E15 "na enfermagem temos alguns problemas, por exemplo, com a nutrição que não conhece a necessidade do paciente". Continua, "tem muita falha na comunicação, entre nós (enfermeiros) e os outros profissionais, se não 
tivesse esta dificuldade o trabalho poderia ser mais ágil, prejudicando menos o paciente".

Ainda em relação à comunicação, percebeutse um esforço dos supervisores em alinhá-la na organização, além disso, mesmo com a grande carga de trabalho, eles conseguem se comunicar formal e informalmente, tanto sobre temas relacionados ao trabalho quanto sobre variedades. Salienta E4, "participo de diálogos com colegas, temos uma reunião mensal com os enfermeiros e uma vez por semana com a divisão". E6 salienta que "comunicome com todos na organização para melhorar meu trabalho, sem restrições, procuro sempre ajudar os outros para ser ajudada, consigo coisas que normalmente ninguém consegue [...] porque eu procuro ser legal”.

A autonomia para decisão, como já salientado, é tida œmo presente em seus trabalhos por todos os enfermeiros que lidam direto com o paciente. Alegam E2, E7 e E10 "nossa ação é detectar o problema e orientar o que deve ser feito, não temos tempo para discutir em grupo, não temos reuniões préestabelecidas para discutir o problema, mas quando tem a necessidade, quando acontece algo fora do normal, leia-se fora do padrão, daí fazemos para compartilharmos". Estas posições mostram que a maioria segue uma rotina de trabalho que, embora variável em número de acontecimentos, é muito conhecida pelos que ali trabalham. Portanto, fica o questionamento, a discricionariedade, por eles chamada de autonomia, não acontece por já saberem os procedimentos por as situações se repetirem com freqüência? Ou seja, dominaram o processo de trabalho, mesmo com amplas possibilidades de variação, e segue um padrão conhecido pela maioria, o que lhes dá independência frente aos supervisores.

A constatação acima se fortifica nas palavras de alguns entrevistados, seguem suas posições, saliente-se que estão a menos de cinco anos no hospital, E2, E3, E6 e E8, respectivamente "os imprevistos acontecem tanto que aprendemos a lidar com eles". "O imprevisto faz parte do nosso trabalho". "até ouvem a minha opinião, mas não dão muita importância". "Eu até já busquei algumas coisas em teorias e pesquisas, mas não adianta dar opinião".

Em relação ao planejamento para execução das atividades, de forma geral, percebeurse que há uma preocupação com ele, $60 \%$ dos entrevistados 
citaram que o fazem, contudo, frente aos desafios diários deixam o planejamento de lado e, na linguagem deles, "fazemos o que tem que ser feito". Como expressam E13, E7, respectivamente, "quando se lida com o ser humano há uma complexidade muito grande, algumas coisas são planejadas, mas dependendo do dia o meu planejamento fica de lado, para eu resolver outras situações". "Lido constantemente com situações inesperadas, não sendo possível definir previamente as atividades que irei desenvolver, sim, tento fazer um planejamento, mesmo com as atividades planejadas, acontecem conforme a necessidade, independente de nosso planejamento".

Como as ações são reguladas, estruturadas, de forma discricionária ou autônoma?

O processo regulatório de ações e decisões apresenta particularidades importantes quando o discutimos frente ao aprendizado necessário. Percebese, como já salientado, que há abertura para conversas fora do contexto de trabalho, contudo, alguns setores, devido a alta carga de trabalho, a comunicação se restringe estritamente ao relacionado com as atividades de trabalho. Como salienta E1 "a minha atividade permite conversas e contato com os outros colegas (profissionais), mas, especificamente, sobre o trabalho". Complementa expondo a orientação para suas ações "recebo instruções da equipe médica e da fisioterapia, mas o contato maior fica com a equipe médica".

Observou-se que os enfermeiros seguem corretamente as instruções que recebem, mas quando há dúvidas, mesmo tendo sido a ordem passada por um médico ou residente, vão em busca de informações e procuram se informar e verificar se o procedimento é o mais apropriado. Expõe E1 "como aqui é um hospital escola, às vezes algumas orientações que eles dão para gente, nós sabemos que não é correta, uma via que ele colocou errado ou uma dose de medicamento, então é preciso confirmar".

Em alguns setores quem faz a prescrição é o residente, em outros, o interno (acadêmico). E1 afirma "neste setor quem faz a prescrição é o residente (formados em medicina). Acontece erro, mas a chance é bem menor. Em 
muitos outros setores são os internos (alunos de medicina) que fazem. A possibilidade de erros é bem maior". O que demonstra a presença da lógica exposta por Arbix \& Sznelwar (2002), "a fronteira entre o que pode e o que não pode ser feito não é rítida, o que, em determinado momento, pode ser tido como adequado para garantir a qualidade, em outro, pode ser contestado". Portanto, o enfermeiro ao tomar uma decisão contrária ao médico, residente ou interno, corre o risco de em determinado momento ser considerado irresponsável. Irresponsável se der errado a correção feita e irresponsável se não corrigir o procedimento errado passado pelo "médico". Ou seja, vive em estado de tensão extrema. O que acaba acarretando prejuízos ao bem estar. Expõe E2 "em relação às condições de trabalho, temos colegas que estão doentes, inclusive depressão. Poderia melhorar a qualidade de vida dentro do trabalho".

Mesmo frente aos desafios da sempre relatividade dos procedimentos, eles têm "autonomia" para resolver os problemas às suas maneiras. Podem dar sugestões aos supervisores para melhorar o trabalho, há abertura para isso. Contudo, sofrem com a autonomia recebida, pois não têm tempo de pensar nas atividades durante o trabalho, e não foi exposto por nenhum entrevistado que durante o trabalho eles podem discutir e aprender com algum procedimento. Como afirma E1 "tenho a todo o momento autonomia para analisar o trabalho que realizo, contudo não há tempo, sinto um desgaste de ir para casa e ainda pensar no que acontece e aconteceram aqui, as falhas e oportunidades. Às vezes, na correria do trabalho não dá tempo para pensar, acabo pensando fora".

Contudo, evidenciourse que algumas decisões principais cabem ao chefe sim. Expõe o entrevistado 19 "se o chefe precisa de mim em um determinado horário e eu não posso, mesmo assim eu preciso obedecê-lo". Os maiores espaços para atuações discricionárias acontece nos plantões, onde o controle é menor. Salienta E6 "tenho autonomia para atuar frente as situações de incertezas, principalmente nos finais de semana, porque nós temos plantão e as supervisoras não estão, daí nós resolvemos tudo sozinhas. Ou nos ligamos, mas dependendo da situação não dá tempo". Aqui também se 
comprova que a regulação das ações na parte administrativa segue uma lógica mecanicista, contudo, na atuação do enfermeiro frente ao paciente, o sujeito é ser ativo e tem liberdade para fazer o que for necessário para resolver o problema.

Expõe E2,

\begin{abstract}
"tenho autonomia para realizar novas experiências, tem uma rotina de atividades principais que devo realizar e dentro desta rotina podemos fazer mudanças se necessário. Preciso pedir permissão pra realizar adaptações nas instruções que recebo. Tudo que vai mudar precisa do aval de alguém. Se caso não encontrar alguém, muda com a cara e a coragem e depois agüenta o rojão!".
\end{abstract}

Todos conhecem as rotinas, mas lidam com surpresas, que na realidade observada, se tornaram rotina, enfim, como existe sempre imprevistos, a própria liderança faz "vistas grossas" frente a procedimentos executados fora do padrão. Os próprios enfermeiros regulam suas ações frente a seu julgamento, sua racionalidade limitada, do que é possível fazer com os recursos que possuem, contudo, pela falta de interação e aprendizagem, acabam não expandindo sua racionalidade e mantendo procedimentos que deram certo, mas não sendo os mais viáveis.

Expõem E8, E14, E3 e E18, respectivamente, "sim, há autonomia para resolvermos imprevistos, desde que seja emergência". "Tem autonomia para realizar novos projetos, mas não temos vontade! Quando se trata de um paciente, sim". "Existem rotinas da unidade, mas temos flexibilidade, dependendo da situação, preciso pedir permissão para realizar adaptações nas instruções sim. Se for urgência não!". "Temos autonomia para reestruturar o processo de trabalho, mas depende da situação. Se esta rotina foge do âmbito da nossa unidade temos que seguir, mas se é da unidade temos que negociar, caso seja urgência faço pelo paciente e pago o preço!".

Percebe-se que a regulação permite abertura, contudo, se a ordem vem de outro setor, como da fisioterapia, por exemplo, devem seguir sem adaptações. Enfim, lidam com a heteronomia, e dentro de seus espaços, já calculados, exercem sua discricionariedade. Relata E4, "converso bastante, sobre o trabalho e outros assuntos também, dependendo da situação eu tenho que modificar os métodos, dentro de alguns parâmetros eu tenho autonomia, 
tem monitoramento das atividades, mas que me permite ações autônomas". Continua "nem sempre as principais atividades estão pré-definidas, eles contam muito com a criatividade da gente, tem um norte e vamos nos adequando".

E17 expõe que "sim, posso dar sugestões, se as propostas são possíveis de execução são implantadas. Estamos, inclusive, tentando padronizar alguns protocolos, para que sejam realizadas adaptações nas instruções recebidas. Em partes eu tenho autonomia para realizar projetos novos. Os enfermeiros, nos setores de contato direto com o paciente, têm mais autonomia de decisão do que eu aqui com a parte administrativa. Minha chefia toma decisão, muitas vezes, a partir do que eu falo".

Tal posição indica que alguns, frente às várias intervenções nas rotinas do processo, estudam regras para guiar as intervenções. O que, pela realidade observada, não será possível. As ações estruturantes seguem um misto de "foco no cliente" (paciente) e defesa de interesses próprios. A organização apresenta fortes traços da lógica organicista, onde há uma preocupação em ouvir e cuidar do indivíduo, contudo, tendo em perspectiva o melhor funcionamento dos processos pré-existentes a eles. É bem próximo ao que acontece no hospital, todos tem liberdade, desde que ela não interfira nas boas práticas dos processos padrões. Corrobora E6, "[...] não relacionado a procedimentos técnicos, mas a nível administrativo podemos melhorar de outras formas, a ordem do médico nós não podemos mudar, se precisar vamos conversar com ele e convencê-lo".

Em relação à questão "preciso pedir permissão para realizar adaptações nas instruções que recebo para alcançar os objetivos esperados?" E8 respondeu "dependendo do conteúdo da informação eu posso mudar, mais para sim, mas preciso dar ciência das coisas. Eles, enfermeiros assistenciais, tem mais autonomia do que eu. Eles podem autorizar e efetivar uma mudança sem consulta". E9 relata "quando eu não sei o que fazer, não faço nada. $\mathrm{Na}$ parte prática, se for vida e morte eu resolvo, na parte administrativa eu espero. Minha equipe é muito legal, mas sempre tem pessoas que destoam, criam intrigas". Complementa E2 "aqui gira muita política, é sofrido ser político, mas temos que ser para conseguir as coisas". 
Como se dá a busca do saber, do saber-fazer e do saber-ser? Eles estão voltados para quê? Como se dá a vinculação do que se aprende com a realidade operacional?

Existe na organização um processo que orienta claramente as ações de formação. Existe um departamento exclusive que cuida dos direcionamentos do que se deve aprender, sempre em consonância com o que é pedido ou sugerido pelos líderes de unidades. Contudo, alguns aspectos importantes puderam ser verificados.

Salienta E1 "os treinamentos que tem são bem específicos para nós (enfermeiros), mas às vezes abrange outros temas, tivemos, por exemplo, um treinamento sobre comportamento. Tem na medida em que precisa. Não é aprofundada, mas acho que nem tem necessidade de ser". Aqui, já começa a se evidenciar uma deficiência das ações de formação no sentido do saber-ser.

Existe na diretoria a possibilidade de aprender com os outros, mas podia ser melhor. Por exemplo, salienta E7 "com os médicos docentes nos temos mais possibilidade de aprender, mas com os médicos que não são docentes é difícil, porque eles passam muito rápidos e não dá tempo para discutir algo com eles". Aqui ressalta-se o mecanismo mais utilizado para o aprendizado, a prática diária.

Outro fator interessante e que a maioria das pessoas está preocupada com o processo de aprendizagem individual, muitas estão fazendo pós-graduação. O grande objetivo da aprendizagem, segundo $90 \%$ dos entrevistados, é melhorar a assistência ao paciente, nada mais.

E2 expõe "meu maior aprendizado advém de minhas próprias experiências, de situações novas onde eu tenho que buscar conhecimentos para resolver. Eu procuro me colocar no lugar da outra pessoa. Usamos o conhecimento adquirido nos treinamentos para melhorar a assistência na prática". Continua "vivencio sempre a prática, porque fixa mais, através das discussões, mas as chefias devem estar preparadas para esta discussão. É mais comum buscarmos novos treinamentos e soluções quando passamos por situações difíceis". 
Embora, foquem o aprendizado na busca da melhoria da assistência ao paciente, os treinamentos mais valorizados são os treinamentos técnicos, diretamente relacionados a área de atuação. Contudo, E6 expõe que:

\begin{abstract}
"é mais difícil lidar com os relacionamentos do que cuidar do paciente, aprender uma técnica nova é fácil. Não somos preparados para este relacionamento, principalmente a forma de falar e como abordar as situações. Não existe planejamento, as coisas acontecem de acordo com a necessidade".
\end{abstract}

E3 relata "ainda preciso aprender muito. Precisamos aprender mais para construir um melhor atendimento ao paciente. Eu converso com os pacientes. Temos uma psicóloga contratada só para este setor, mas o trabalho dela não atinge os objetivos".

Em relação à orientação para a oferta dos treinamentos, E6 expõe que "o treinamento tem que partir de cada setor e a diretoria sabe o que precisa lançar para os enfermeiros". Segundo E8:

\footnotetext{
"uma vez por ano os setores solicitam os treinamentos. Alguns treinamentos sempre vão ter, são básicos (cateter, curativo, pic). Contudo, muitos não admitem que precisam de treinamento. Às vezes é pago hora extra e as pessoas não vem. Quem dá o exemplo de ir ao treinamento é o chefe. Ele tem que valorizar e incentivar. Tenho a liberdade de chamar as pessoas que precisam se capacitar, mas sempre com muita política e uma abordagem sedutora. As pessoas não estão sendo cobradas em manter o conhecimento. Outros hospitais não tem nada de cursos, então aqui é uma grande oportunidade".
}

Fato comprovado por E4 "A minha vivência me permite isto. Tenho condições de saber qual conduta ter na instituição, independente dos treinamentos, porém os treinamentos ajudam a melhorar atitudes".

Em relação aos questionamentos se os treinamentos provocam mudanças no dia-a-dia, E4 relata que "sim, os treinamentos refletem mudanças no local de trabalho, mas se sustenta por um curto período. Por isso as reuniões são importantes. Para todos se capacitarem constantemente".

Interessante perceber que o aprendizado não se mantém, inclusive, observourse que certos treinamentos acontecem constantemente, repetitivamente. Fica a questão, por que o aprendizado não se mantém. Será 
que está restrito a algumas pessoas? Evidencia-se que o conhecimento tácito prevalece. Não havendo ações estruturadas para explicitar os conhecimentos, bem como para tornar tácitos os conhecimentos explícitos. Enfim o ciclo proposto por Nonaka e Takeuchi não se confirma. Com isso, o ciclo de aprendizagem proposto por Kim, também não se completa, fica restrito à aprendizagem operacional, ou seja, prevalece a aprendizagem individual em ciclo único.

As constatações podem ser observadas nas palavras dos entrevistados E2, E1, E7, E14, E1, E4 e E16, respectivamente, "as reflexões das experiências vivenciadas acontecem somente nos treinamentos". "Muitas julgam que deveria haver melhor organização do aprendizado, ou melhor, do conhecimento, para aprender mais e evoluir [...] mas o dia-a-dia nos consome...". "não dá tempo para procurarmos teorias e pesquisas sobre o que aprendemos". "Fomos treinados no dia-a-dia. Fomos jogados em UTI sem saber mexer em respirador, a nossa sorte é que os fisioterapeutas nos ensinam. Treinamento qualificado nós não temos". "Mesmo assim, depois de um tempo que aconteceu o treinamento muitas coisas voltam a ser como antes, por falta de motivação, entre outros". "Faz tempo que não nos juntamos para refletir. Neste último ano tivemos umas 3 reuniões". "A maior fonte de aprendizagem é o próprio trabalho".

Percebe-se que embora haja um forte incentivo para a busca do aprendizado na organização, ele fica restrito aos treinamentos, na maioria das vezes, é realizado em sala de aula, conforme prevê a lógica do sistema, fora do contexto real. A ponte do que foi treinado com a realidade é atravessada por poucos. De acordo com o E4 "a aprendizagem enfoca a aprendizagem para a identificação de problemas, pois os treinamentos são feitos para resolver problemas que já aconteceram". Continua, "as atividades que levam as pessoas a melhorarem no lidar com imprevistos são as experiências na prática". O que demonstra a individualidade do processo de aprendizagem. $O$ que é confirmado por E12, "a educação não acontece somente nos treinamentos, mas também na prática. O enfermeiro precisa ensinar sempre".

Os acontecimentos, bons e ruins, são registrados na ficha funcional, todos são avaliados. No final do ano realizam-se oficinas sobre os acontecidos, 
daí, a partir das necessidades levantadas, o comitê de treinamento, já com as orientações dos supervisores, avalia e decidem quais serão realizados. Caso tenha uma necessidade é possível criar um novo treinamento, assim são definidos os temas para os treinamentos. Contudo, salienta E10:

\begin{abstract}
"durante 0 ano as pessoas não participam muito dos treinamentos, mas esperamos melhorar. Falta divulgar melhor este treinamento. É complicado tirar o pessoal do trabalho. Falta estratégia para motivar estas pessoas, os supervisores motivarem mais e levantar os interesses. A partir das necessidades levantadas o comitê avalia e decidem quais serão realizados. Caso tenha uma necessidade é possível criar um novo treinamento".
\end{abstract}

Percebe-se claramente que a preocupação maior é com as ações de formação e menos com o aprendizado, aliás, não se verificou nas respostas, algo que comprovasse preocupação e ações frente à aprendizagem individual e conseqüentemente organizacional. Redunda-se, o foco principal está nos treinamentos em si, com pressupostos organicistas.

Em relação às dificuldades frente aos treinamentos oferecidos, encontrou-se, além das já citadas, muito desinteresse individual, muitos têm dois empregos, portanto, não há tempo disponível para realizar o treinamento. De acordo com E3, "parte das pessoas quererem aprender, temos a internet, a biblioteca com um acervo muito grande, o dia-a-dia e a troca de informações com os melhores profissionais, que entram e saem daqui”. Mas conforme expõe E1, "quem deve ter interesse é o funcionário. Esse é o problema. Às vezes, tem treinamento, mas o funcionário não participa. No holerite, todo mês, vem a programação mensal dos treinamentos que serão oferecidos, daí o funcionário escolhe qual se inscrever. Não é obrigatório. A maior parte dos treinamentos é dada de forma geral para todos, sem particularidades". Contudo, ressalta E3,:

Devido a meu interesse "tenho certeza que estou cada vez mais preparado para lidar com situações complexas sim. Aqui se adquire muito conhecimento. Eu sempre venho aqui para aprender. Sairei muito engrandecido por tudo que eu aprendi. Tenho muita vontade de voltar a trabalhar aqui através de um concurso, pois aqui o enfermeiro tem muitas oportunidades de aprendizagem". 
E6 expõe que "muitas vezes depois do treinamento temos que buscar mais, conforme nossa área de atuação, a pessoa tem que ter vontade para complementá-lo". Contudo, a maioria não tem. Ficando o treinamento com o caráter de "lembrete" ou algo que tem que acontecer, sem o vínculo necessário com o aprimoramento no dia-a-dia.

O feedback sobre o treinamento ocorre somente depois de encerrado o curso, ou seja, é sobre o curso, se foi bom, se atendeu as expectativas, não há mecanismos de verificação sobre o resultado prático do treinamento. Como salienta E20 "somente verificamos se o treinamento gerou mudanças, nas observações informais que alguns fazem, não há mecanismos formais". Confirmando mais uma vez o foco no treinamento. E14 relata "auxilio na identificação da aprendizagem, indico os treinamentos na comissão que eu participo".

Não se encontrou registros de ações de gestão do conhecimento. Os ciclos propostos por Nonaka e Takeuchi (1995) e Kim (1998), ficam distantes de acontecer na íntegra, até mesmo a aprendizagem em ciclo único (single loop) é duvidosa.

O aprendizado não é duradouro. Se não existir cobrança acaba a voltando nos mesmos erros. Quem determina os aprendizados (leia-se treinamentos) é o departamento de treinamento junto com as supervisoras. Percebeu-se que os treinamentos mais freqüentados são os específicos da área de atuação. $90 \%$ dos entrevistados salientam que aprendem coisas novas dia-a-dia, os próprios funcionários se oferecem para dar cursos. O porque dos treinamentos, todos responderam, como já salientado, "para um melhor atendimento". "Só não aprende (diga-se, treina) quem não quer, porque oportunidade aqui nós temos muito. Quando acontece na hora do trabalho, nem sempre os funcionários podem deixar o setor para participar. Quando é muito importante para o setor é pago um extra para todos participarem". Salienta E2.

Uma dificuldade das ações de formação, as pessoas têm dificuldade de seguir o planejamento estratégico. Acabam esquecendo. Focam no presente, nas exigências do dia-a-dia. Salienta E11, "deveríamos treinar isso, 
pois treinamento é uma reação a alguns comportamentos, falhas como esta, não seguir o planejado, precisa ser melhorada". Continua, "tem que ter treinamento constante para obter mudanças no local de trabalho. Para ter atitudes adequadas sempre. A supervisão é muito importante e a educação deve ser continuada". Corrobora E7, "às vezes nos retrocedemos em atitudes que davam certo, pois, infelizmente apenas alguns estão em situação de aprendizagem".

Quais são as maneiras de ver a formação?

A forma com que os próprios funcionários da diretoria de enfermagem vêem a formação, de forma mais detalhada, reforça um bloqueio no ciclo de aprendizagem. Salienta E1, "falta interesse das pessoas pelo treinamento. Acho que nem se eles fossem obrigatórios dariam certo. Talvez a supervisora pudesse incentivar mais". Complementa "poucas pessoas estão em processo de aprendizagem individual'.

$50 \%$ dos entrevistados salientaram que queriam que houvesse mais atividades de formação para lidar melhor com imprevistos. Nós aprendemos no susto, ás vezes fazendo errado, fui treinada com as colegas do setor. Eu não tive uma recepção por ser nova. Fiz alguns treinamentos aqui. Destaca E12.

Alguns $40 \%$, sugerem que os treinamentos sejam modulares, específicos de cada setor, seria mais atrativo e assertivo em resultados. Antes do treinamento deveria ser feito um levantamento da carência de cada um. "Eu estou aqui há quase 2 anos e nunca tive a oportunidade de ter esta possibilidade". Expõe E10.

O próprio ser humano é a barreira para obter mais conhecimento. Ele é o fator que mais impede o crescimento. E8 relata que "tenho como atuar nas incertezas sim, mas há falta de comunicação e isso interfere muito no nosso trabalho. Precisa melhorar muito mais".

O quadro 9 sintetiza as respostas principais conforme sua incidência. 
Quadro 9 - VISÃO GERAL DO CONTEXTO DE APRENDIZAGEM

\begin{tabular}{|c|c|c|}
\hline CATEGORIA & VARIÁVEL & $\begin{array}{c}\text { ENTREVISTADOS RESPONDENTES } \\
\text { VOLUME DE INCIDÊNCIAS }\end{array}$ \\
\hline $\begin{array}{l}\text { NATUREZA } \\
\text { DO } \\
\text { PROCESSO } \\
\text { DECISÓRIO }\end{array}$ & Autonomia & $\begin{array}{l}{ }^{*} \text { Reestruturar o trabalho: } 1,2,4,7,8,19 \text { e } 20 \\
\text { Depende da complexidade: } 3,5 \text { e } 16 \\
\text { * Decisões principais são do chefe: } 2,3 \text { e } 14 \\
\quad \text { Algumas vezes: } 1,5,6,7,9,18, \text { e } 10 \\
{ }^{*} \text { Frente a situações de incertezas: } 1,12,4,5,8 \text { e } 10 \\
\quad \text { Procuro ajuda de colegas: } 3,6,17,7 \text { e 9 } \\
\text { * Para planejar modificações no trabalho: 1, 3, 4, 5, } 7 \text { e } 10 \\
\text { Vai acontecendo: } 2,6,8 \text { e } 9 \\
\text { * Liberdade para rejeitar ordens superiores: 1, 13, 4, } 15 \text { e } 6 \\
\quad \text { Não convém: } 2,7,8,9 \text { e } 10 \\
\text { * Sua opinião é importante: TODOS }\end{array}$ \\
\hline \multirow[t]{2}{*}{$\begin{array}{c}\text { APRENDIZA } \\
\text {-GEM }\end{array}$} & Comunicação & $\begin{array}{l}\text { *Intra e entre as áreas: } 2,7,9 \text { e } 10 \\
\quad \text { Existem falhas: } 1,3,4,5,6 \text { e } 8 \\
\text { * Reflexão das experiências vivenciadas: } 1,7,8 \text { e } 10 \\
\quad \text { Pouca: } 2,13,4,15,6 \text { e } 9 \\
\text { *Interação para melhorar o trabalho: } 3,4,7,9 \text { e } 10 \\
\quad \text { Pode melhorar: } 1,2,5,6 \text { e } 8\end{array}$ \\
\hline & Aprendizagem & $\begin{array}{l}\text { *Aprender com os outros: TODOS } \\
\text { * Processo individual: } 1,4,6,7,8 \text { e } 9 \\
\quad \text { Poucos: } 2,3,5 \text { e } 10 \\
\text { * Para lidar com imprevistos: } 3,4,6,7,9 \\
\quad \text { Na prática: } 1,2,5,8 \text { e } 10 \\
{ }^{*} \text { Passar informações repetitivas: TODOS }\end{array}$ \\
\hline FORMAÇÃO & Treinamento & 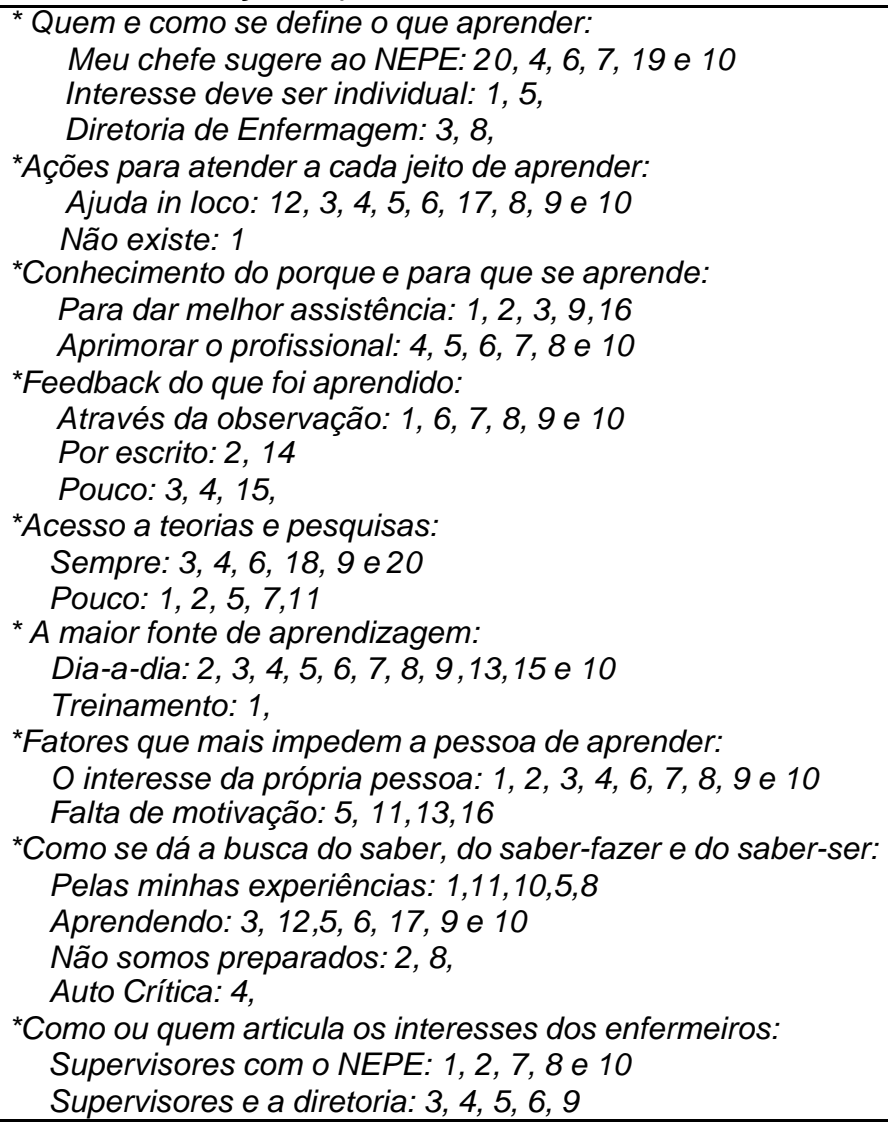 \\
\hline
\end{tabular}

O quadro 10 sintetiza a incidência de praticamente todos os constrangimentos possíveis à aprendizagem retirada do referencial teórico. Destacando-se os constrangimentos à aprendizagem organizacional. O quadro 
pode ser lido da seguinte maneira, de acordo com o constrangimento, anotour se sua citação pelo entrevistado. Então, por exemplo, à possibilidade de reflexão sobre o aprendido, 50\% dos entrevistados anotaram sua existência.

Quadro 10 - CONSTRANGIMENTOS x CITAÇÕES PELOS ENTREVISTADOS

\begin{tabular}{|c|c|c|}
\hline CONCEPÇÕES & $\begin{array}{c}\dot{A} \text { APRENDIZAGEM } \\
\text { INDIVIDUAL }\end{array}$ & $\begin{array}{l}\text { A APRENDIZAGEM } \\
\text { ORGANIZACIONAL }\end{array}$ \\
\hline $\begin{array}{l}\text { - SISTEMA SOCIAL } \\
\text { PRÉ- } \\
\text { DETERMINADO EM } \\
\text { RELAČ̃̃O AOS } \\
\text { SUJEITOS } \\
\text { AGENTES }\end{array}$ & 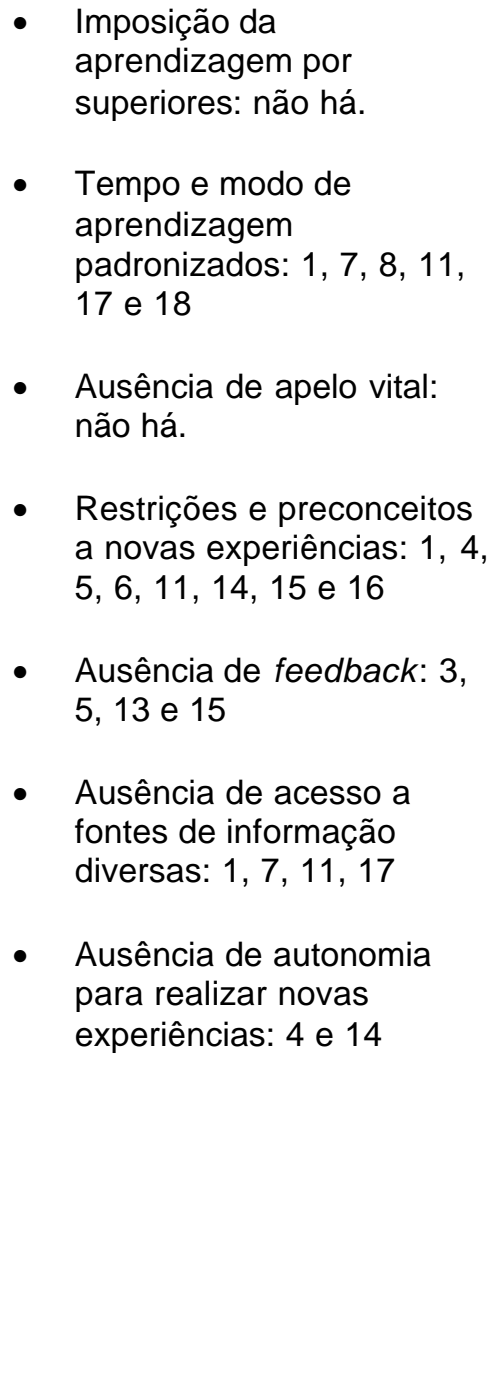 & $\begin{array}{l}\text { - Canais de comunicação } \\
\text { rígidos: } 3,5,13 \text { e } 15 \\
\text { - } \quad \text { Impossibilidade de observar o } \\
\text { trabalho dos demais } \\
\text { trabalhadores: todos disseram } \\
\text { que aprendem muito com os } \\
\text { outros. } \\
\text { - } \quad \text { Ausência de interação com os } \\
\text { demais trabalhadores: } 5 \text { e } 15 \\
\text { - } \quad \text { Atividades limitadas e } \\
\text { rotineiras: } 1,5,6,10,11,15,16 \\
\text { e } 20 \\
\text { - Informações limitadas: } 5,10, \\
15 \text { e } 20 \\
\text { - Impossibilidade de } \\
\text { exteriorização do } \\
\text { conhecimento: não há } \\
\text { Ausência de autonomia para } \\
\text { resolver imprevistos: } 1 \mathrm{e} 11 \\
\text { Ausência de disponibilidade } \\
\text { dos trabalhadores para } \\
\text { reflexão-coletiva: } 2,3,5,7,9 \text {, } \\
12,13,15,17 \text { e } 19 \\
\text { - Limitações à aprendizagem } \\
\text { individual: } 2,3,5,6,9,12,13 \text {, } \\
15,16 \text { e } 19\end{array}$ \\
\hline
\end{tabular}


Continuação quadro 10.

\begin{tabular}{|c|c|c|}
\hline $\begin{array}{l}\text { - SISTEMA SOCIAL } \\
\text { PRÉ- } \\
\text { DETERMINADO EM } \\
\text { RELACCÃO AOS } \\
\text { SUJEITOS } \\
\text { AGENTES } \\
\\
\text { ORGANICISTA }\end{array}$ & $\begin{array}{l}\text { - Imposição da } \\
\text { aprendizagem por } \\
\text { superiores: não há. } \\
\text { - Tempo e modo de } \\
\text { aprendizagem } \\
\text { padronizados: } 1,7,8,11 \text {, } \\
17 \text { e } 18 \\
\text { - Restrições e preconceitos } \\
\text { a novas experiências: } 1,4 \text {, } \\
5,6,11,14,15 \text { e } 16 \\
\text { Limitações ao acesso a } \\
\text { fontes de informação } \\
\text { diversas: } 1,7,11,17 \\
\text { Ausência de autonomia } \\
\text { para realizar novas } \\
\text { experiências: } 4 \text { e } 14\end{array}$ & $\begin{array}{l}\text { - Ausência de autonomia para } \\
\text { resolver imprevistos: } 1 \text { e } 11 \\
\text { - } \\
\text { Alto grau de estabilidade dos } \\
\text { processos realizados: } 1,7,8, \\
11,17 \text { e } 18 \\
\text { - Limitações à reflexão coletiva: } \\
2,3,5,7,9,12,13,15,17 \text { e } 19 \\
\text { - Limitações à aprendizagem } \\
\text { individual: } 2,3,5,6,9,12,13, \\
15,16 \text { e } 19\end{array}$ \\
\hline $\begin{array}{l}\text { SISTEMA SOCIAL } \\
\text { CONSTRUIDO } \\
\text { PELAS } \\
\text { INTERAÇÕES DOS } \\
\text { SUJEITOS }\end{array}$ & 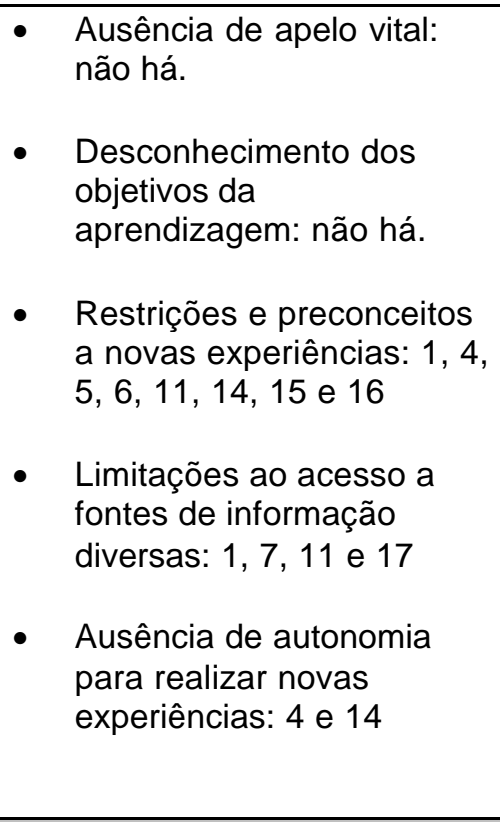 & $\begin{array}{l}\text { - Limitações aos meios de } \\
\text { comunicação entre os sujeitos: } \\
3,5,13 \text { e } 15 \\
\text { - Limitações à interação entre os } \\
\text { sujeitos: } 5 \text { e } 15 \\
\text { - Limitações à reflexão coletiva: } \\
2,3,5,7,9,12,13,15,17 \text { e } 19 \\
\text { - Limitações à aprendizagem } \\
\text { individual: } 2,3,5,6,9,12,13 \text {, } \\
15,16 \text { e } 19 \\
\text { - Restrições ao fluxo de } \\
\text { informações circulante: } 5,10, \\
15 \text { e } 20 \\
\text { - Ausência de autonomia para } \\
\text { lidar com imprevistos: } 1 \text { e } 11\end{array}$ \\
\hline $\begin{array}{l}\text { - AGIR } \\
\text { ORGANIZACIONAL } \\
\text { - PROCESSO DE } \\
\text { AÇÕES E } \\
\text { DECISÕES }\end{array}$ & Não identificado. & Não identificado. \\
\hline
\end{tabular}

Sabe-se, que segundo Maggi (2006) a aprendizagem deveria fazer encontrar dispositivos que se baseiam no encontro de três eixos. O primeiro é o dos saberes metodológicos provenientes da teoria do agir organizacional, na qual os sujeitos precisam desse saber para analisar, avaliar e modificar seu 
processo. O segundo é o das competências específicas dos sujeitos do processo, em que, é a partir de suas competências, inerentes às ações de trabalho, e nelas e por elas desenvolvidas, que os sujeitos podem apropriar-se do método do qual necessitam. E o terceiro é o da epistemologia que a abordagem pressupõe que colocam em relação os saberes metodológicos do agir organizacional e as competências intrínsecas ao processo de trabalho. Verifica-se que o terceiro eixo não se consolida e atua como forte impedimento à aprendizagem na realidade estudada. 


\section{9.) CONCLUSÃO E CONSIDERAÇÕES FINAIS}

Percebeu-se que o estudo sob o tema proposto agrega informações importantes sobre o processo de aprendizagem nas organizações. A proposta de Maggi (2006), de discutir não somente a ação mais o agir organizacional permite alcançar debates que extrapolam o subjetivismo e o objetivismo. A abordagem se aproxima do que deveria ser o modelo real das organizações para contextos macro-econômicos atuais.

Na presente pesquisa, explorourse relações importantes e evidenciourse que a concepção organizacional realmente, no caso estudado, influencia nas formas de conceber a formação. A partir desta constatação, percebeurse na prática que a racionalidade, tanto individual quanto coletiva, orientada pela concepção de organização define rumos e constrangimentos. Em relação aos constrangimentos, constatourse são elementos que impedem a evolução organizacional, no caso estudado. Pois limitam a ampliação da racionalidade. $\mathrm{Na}$ organização embora exista uma política clara e bem definida de treinamentos. Está muito focada no treinamento em si. Além disso, segue as propostas de formação da lógica do sistema/organicista. Ou seja, "cabe aos trabalhadores apenas decisões de menor impacto estrutural, que não alteram a organização em seus fundamentos e processos, mas apenas asseguram uma melhor adequação das atividades às necessidades tanto do ambiente quanto do sujeito.

A formação acontece em sala de aula, a partir de uma coleta coletiva sobre o que deve ser treinado. Observa-se que o "que deve ser treinado" esta restrito à realidade interna, com poucas consultas a acontecimentos externos. Tendendo a manter a aprendizagem operacional em loop único como propõem Kim (1998) e Argyris (2002).

Conforme a existência dos constrangimentos expostos no quadro 10 e sua incidência conforme os entrevistados, percebe-se que a organização tem 
uma estrutura de formação, centrada na formação unicamente. Seria importantíssimo um debate acerca da mudança para o modelo double loop, pois com isso, multiplicaria um saber rico, presente tacitamente nos indivíduos. Como ações orientadas pela DEPE, que apresenta condições para isto, a DE poderia rapidamente se tornar uma organização de aprendizagem. Pois saber, e saber-fazer, como ressaltado existe, só falta o compartilhamento. Em suma, falta fazer girar os ciclos propostos por Nonaka e Takeushi (1995) e Kim (1998).

Estas constatações foram possíveis à medida que se observou o processo de ações e decisões, ações reguladoras dos processos de formação e aprendizagem. Enfim, analisou-se sob a perspectiva do agir estruturante ou regulador proposto por Maggi (2006) em sua teoria do agir organizacional.

Ainda na perspectiva do agir, percebeurse que a formação na organização se encaixa, quase totalmente, na lógica de formação presente na lógica do sistema organicista. Muitos acreditam ter autonomia, mas gozam de espaços discricionários para suas ações. Percebeu-se que na parte administrativa a discricionariedade é bem menor. Contudo, na ação de assistência direta ao paciente, quando envolve vida ou morte, o enfermeiro tem autonomia para agir da forma que achar melhor, é o mais próximo que a organização chega das propostas do agir organizacional. Pois para se aproximar mais seria necessário ter como característica intrínseca a possibilidade estratégica de produção de ordem, ou seja, de compreensão, construção e reconstrução do processo de regulação, reorganizando o processo de ações e decisões se auto-organiza. Passado este momento, ele volta para seus espaços discricionários abertos pelo processo decisório. Além disso, o aprendizado adquirido, com estas experiências fica restrito a ele, que a partir dai pode propor um treinamento para lidar com os problemas enfrentados.

Percebeu-se também, por ser uma organização pública, a incidência de algumas características citadas pela lógica do ator, principalmente no que tange à obediência da corrente que está no poder. Embora a quebra de regras seja permitida, principalmente quando se refere ao bem estar do paciente, 
muitos não o fazem para não contradizer o poder instituído. Os que fazem, discutem posteriormente o que fazer frente à divergência. Portanto, só é possível explicar a ação depois de acontecida.

Em relação às conseqüências ao processo de formação, percebeuse que: os treinamentos são bem planejados, contudo, não contam com uma visão externa e, portanto, estão sujeitos aos efeitos da racionalidade limitada, ninguém sabe exatamente o que realmente precisaria ser treinado, muitos não aderem por desinteresse e falta de tempo; além disso, não apresentam uma relação próxima com os processos de aprendizagem, pois não há verificação formal do aprendido, somente do treinado. Ou seja, não existem na organização mecanismos formais para discussão da aprendizagem individual e organizacional, bem como da Gestão do conhecimento. Muitos treinamentos são feitos por si. Têm objetivos claros, contudo, os treinados não levam conscientemente e continuamente $o$ aprendido para sua prática e a par daí o compartilham.

Enfim, evidenciourse que a busca do saber, saber-fazer e do saber ser, acontece, efetivamente, na prática diária, não nas práticas de formação. Portanto, a vinculação do se aprende com a realidade operacional, se dá de maneira muito própria, no campo do tácito para o tácito. Como já salientado, atuando como um forte constrangimento ao aprendizado organizacional. Como salienta Dodgson (1993), se não compreendidos e revisados os processos, a aprendizagem ficará restrita aos padrões internos (racionalidades) que corroborarão paradigmas pouco confiáveis do ponto de vista das novas exigências competitivas.

A contribuição científica para o campo da teoria das organizações está centrada na profunda análise de uma obra que por si só já é uma síntese da evolução da teoria das organizações ao longo dos anos. Explorar as concepções da transformação por Maggi sugeridas joga luz em uma questão diferencial quando tratamos da adequação de treinamentos e desenvolvimentos necessários para o crescimento de competências relevantes para a evolução da gestão organizacional. Evidenciou-se que as práticas de treinamento e desenvolvimento são, em grande parte, desvinculadas das reais necessidades de aprendizagem, provocando um efeito ilusório sobre o 
desenvolvimento individual e organizacional. A melhor compreensão da lógica dominante permitirá às organizações reverem seus processos de formação no sentido de torná-los mais eficazes, consistentes e reais. 


\section{REFERÊNCIAS}

ANDERSON, L. Argyris and Schön's theory on congruence and learning [On line]. Available at http://www.scu.edu.au/schools/gcm/ar/arp/argyris.html. 1997.

ARBIX, G. \& SZNELWAR, L. Trabalho, Controle e Impedimento no Setor de Serviços. In: SILVA, J. et al. (orgs). Crítica Contemporânea. São Paulo: Anablume, 2002.

ARGYRIS, C. and SCHÖN, D. Theory in Practice. San Francisco: JosseyBrass, 1974.

ARGYRIS, C., Putnam, R., \& McLain Smith, D. Action science: concepts, methods, and skills for research and intervention, San Francisco: JosseyBass. 1985.

ARGYRIS, C. On organizational learning. Massachusetts: Blackwell Publishers, 1994.

ARGYRIS, C. Double - loop learning, teach and research. Academy management learning and education. v. 1, n.2, p. 206-218, 2002.

BANDIN, Laurence. Análise de conteúdo. $3^{\underline{a}}$ ed. Lisboa/Portugal : Edições 70, 2004.

BARNARD, C. I. The functions of the executive. . $30^{\circ} \mathrm{Ed}$. Cambridge, Harvard University Press, 1968.

BLAU, P. M.; SCOTT, W. R. Organizações formais: uma abordagem comparativa. Trad. Maria Ângela e Lobo de Freitas Levy. São Paulo: Atlas, 1970.

BOTERF, G. Desenvolvendo a competência dos profissionais. Trad. Patrícia C. R. Reuillard. Porto Alegra: Artmed, 2003. 
BOUYER, G. C. A Categoria "Impedimento" como Objeto de Investigação: Uma Aproximação pelo Reverso do Trabalho. XXIV ENEGEP. Florianópolis, SC, Brasil. 03 a 05 de novembro de 2004.

BURNS, T. and STALKER, G. The management of innovation. London: Tavistock Publ., 1961.

BURRELL, Gilson; MORGAN, G. Sociological paradigms and organization analys. Hants: Ashgate, 2006.

CALDERANO, M. A. Notas sobre a fenomenologia social de Schutz. Revista Estudos de Sociologia Online, Universidade Federal do Pernambuco, 2007. Disponível em: http://www.ufpe.br/eso/revista7/social.html Acesso em: 25/09/2007.

CASSEL, C.; SYMON, G. Qualitative Methods in Organizational Research: A pratical Guide. UK, SAGE Publications Ltd, 1994.

CHAUÍ, Marilena. Conformismo e resistência. $3^{\circ}$ ed. São Paulo: Brasiliense, 1989.

. Os trabalhos da memória. IN: BOSI, Ecléa. Memória e sociedade: lembranças de velhos. 2 ed. São Paulo: T.A. Queiroz, pp. 17-33. 1987.

CLOT, Y. A função psicológica do trabalho. Trad. Adail Sobral. Petrópolis: Vozes, 2006.

CROZIER, M. O fenômeno burocrático: ensaio sobre as tendências burocráticas dos sistemas de organização modernos e suas relações, na França, com o sistema social e cultural. Trad. Juan A. G. Sobrinho. Brasília: Editora Universidade de Brasília, 1981.

COOPER, Donald. R.; SCHINDLER, Pamela. S. Métodos de Pesquisa em Administração. Porto Alegre: Bookman, 2003.

CYERT, R. and MARCH, J. A Behavioral theory of the firm. E.C., New Jersey: Prentice-Hall, 1963. 
DEMO, Pedro. Pesquisa e informação qualitativa. São Paulo: Papirus, 2001.

DE GEUS, A. Planning as learning. Harvard Business Review, March/April, v. 66, n. 2, p. 70-74, 1988.

DODGSON, M. Organizational learning: a review of some literatures. Organization Studies, v. 14, n. 3, pp. 375-94, 1993.

DUNCAN, R. and WEISS, A. Organizational learning: implications for organizational design. Research in Organizational Behavior, v. 1, pp. 75-123, 1979.

DUTRA, J. S. Competências: conceitos e instrumentos para a gestão de pessoas na empresa moderna. São Paulo: Atlas, 2004.

HEDBERG, B. How organizations learn and unlearn? In: NYSTROM, P. and STARBUCK, W. (Eds.), Handbook of Organizational Design. London: Oxford University Press, 1981, p.8-27.

FAYOL, H. Administração industrial geral. Trad. Irene de Bojano e Mário de Souza. $8^{\mathrm{a}}$ ed. São Paulo: Atlas, 1970.

FIOL, C. and LYLES, M. Organizational learning. The Academy of Management Review, v. 10, n. 4, pp. 803-813, 1985.

FLEURY, A. e FLEURY, M. Aprendizagem e Inovação Organizacional: As Experiências do Japão, Coréia e Brasil. 2a ed. São Paulo: Atlas, 1997.

FLEURY, M. T. L.; OLIVEIRA, M. M. J. Aprendizagem e gestão do conhecimento. in As pessoas na organização. São Paulo: Editora Gente, 2002.

GARVIN, D. Building a learning organization. Harvard Business Review, v. 71, n. 4, p. 78-91, 1993.

GIDDENS, Antony. New rules of sociological method: a positive critique of interpretative sociologies. Londor, Hutchinson, 1976. 
. The constituition of society. Cambridge, Polty Press, 1984.

GODOY, A.S. Introdução á pesquisa qualitativa e suas possibilidades. Revista de Administração de Empresas, Rio de Janeiro, v.35, n.2, p.57-63, abr./mar, 1995.

$\mathrm{KIM}$, Daniel $\mathrm{H}$. O elo entre a aprendizagem individual e a aprendizagem organizacional. IN: KLEIN, D. A. A gestão estratégica do capital intelectual. Rio de Janeiro: Qualitymark, , pp.61-92, 1998.

KOLASA, B. J. Ciência do comportamento na administração. São Paulo: LTC, 1978.

KOLB, David A.; RUBIN, Irwin M.; McINTYRE, James M. Psicologia organizacional. Uma abordagem vivencial. São Paulo: Atlas, 1978.

D. A. Experiential learning: experience as the source of learning and development. New Jersey: Prentice Hall, 1984.

D. A gestão e o processo de aprendizagem. IN: STARKEY, Ken. Como as organizações aprendem. São Paulo: Futura, pp. 321-341, 1997.

LAZARINI, S. Estudos de caso: aplicabilidade e limitações do método para fins de pesquisa. Economia \& Empresa, São Paulo, 2(4), p.17-26, 1995.

LAWRENCE, P.; LORSCH, J. W. O desenvolvimento da organização: diagnóstico e ação. São Paulo: Edgar Blüncher, 1972.

LIKERT, R. Novos padrões de Administração. $2^{a}$ ed. Trad. Albertino Pinheiro Jr. e Ernesto D’Orsi. São Paulo: Pioneira Editora, 1979.

MAGGI, B. Do agir organizacional: um ponto de vista sobre o trabalho, o bem estar, a aprendizagem. Trad. Laerte Idal Sznelwar. São Paulo: Edgard Blüncher, 2006.

MARCH, J. G.; SIMON, H. A. Teoria das organizações. Trad. Hugo Wahrlich. 5ª ed. Rio de Janeiro: Editora da Fundação Getúlio Vargas, 1981. 
MARTIN, J. Stories and scripts in organizational settings. In: HASTORF, A. and ISEN, A. (Eds.), Cognitive Social Psychology. New York: Elsevier-North Holland, 1982. p. 225-305.

MARTINS, G. A. Estudo de caso: uma estratégia de pesquisa. São Paulo: Atlas, 2006.

MINER, A. and MEZIAS, S. Ugly duckling no more: pasts and futures of organizational learning research. Organizational Science, Jan.-Feb., v. 7, n. 1, pp. 88-99, 1996.

MITROF, I. and KILMANN, R. On organization stories: an Approach to the design and analysis of organizations through myths and stories. In: KILMANN, R., PONDY, L., and SLEVIN, D. (Eds.), Management of Organization Design. New York: Elsevier-North Holland. 1976. Vol. 1, p. 189-207.

MINTZBERG, Henry. Criando organizações eficazes. São Paulo : Atlas, 2006.

MORAES, Roque. Análise de Conteúdo. Porto Alegre, PUCRS, mimeo, 1993. . Roque. Análise de Conteúdo. Revista Educação. Porto Alegre. № 37. Março 1999.

MORIN, Edgar; Le MOIGNE, Jean-Lois. A inteligência da complexidade. $2^{\circ}$ ed. São Paulo: Peirópolis, 2000.

MOTTA, F. C. P; VASCONCELOS, I. G. Teoria geral da Administração. 3 $3^{\underline{a}}$ ed. São Paulo: Thomson Learning, 2006.

NONAKA, I. TAKEUCHI, $H$. The knowledge-creating company: how Japanese companies create the dynamics of innovation. New York: Oxford University Press, 1995.

REED, Michael. Teorização Organizacional: um Campo Historicamente Contestado. In: CLEGG, Stewart, R.; HARDY, C.; NORD, W.R. Handbook de estudos organizacionais. Vol I. São Paulo: Atlas, 1999. Capítulo 1, p. 61-98. 
REYNAUD, Jean Daniel. Les régulations dans lês organisations: régulaton de contrêole et régulation autonome. Revue française de sociologia, 29, 1,5-18. 1988.

RILEY, P. A structurationist account of political culture. Administrative Science Quartely, 28, 414-437, 1983.

ROSSETTI, J. P. Introdução à economia. 20ª ed. São Paulo: Atlas, 2003.

SAMPIERI, R; COLLADO, C.;LÚCIO, P. Metodologia de la investigacion. México, McGraw-Hill, 1991.

SELLTIZ, C. et al. Métodos de pesquisa nas relações sociais. São Paulo: Herder, 1987.

SENGE, P. M. A quinta disciplina. São Paulo: Best Seller, 1990.

SIMON, Herbert A. Administrative behavior. 4를 Ed. New York, McMillan, 1997.

SCHWARTZ, Y. Os Ingredientes da Competência: Um Exercício Necessário para uma Questão Insolúvel. Educação \& Sociedade, n.65, p.101-139, dez. 1998.

SOTO, E. Comportamento organizacional: o impacto das emoções. Trad. Jean Pierre Marras. São Paulo: Pioneira Thomson Learning, 2005.

STATA, R. Organizational learning: the key to management innovation.

Sloan Management Review, v. 30, p.63-74, 1989.

SZNELWAR, L.; MASCIA, F. L. The Organisation of Work Based on Standardisation: The Question of Scripts in Call Centers. Human Factors in Organizational Design and Management, 6, p.647-652, 1998.

TAYLOR, F. W. Princípios da Administração Científica. Trad. Arlindo V. Ramos, 8aㅡ ed. São Paulo: Atlas, 1990. 
THOMPSON, J. D. Dinâmica organizacional: fundamentos sociológicos da teoria da administração. Trad. Gert Meyer. São Paulo: McGraw-Hill do Brasil, 1976.

TRIVINOS, Augusto Nibaldo Silva. Bases teórico-metodológicas da pesquisa qualitativa em ciências sociais. Porto Alegre: Ritter dos Reis, 2002.

VERGARA, S. C. Projetos e relatórios de pesquisa em administração. São Paulo: Atlas, 1998.

WEBER, M. A "objetividade" do conhecimento nas ciências sociais. Trad. Gabriel Cohn. 1973. In: COHN, G. (org.). Weber. $7^{\text {an }}$ ed. São Paulo: Atlas, 2004

WEICK, K. A psicologia social da organização. Trad. Dante Moreira Leite. São Paulo: Edgar Blüncher, 1973.

WILMOTT, $\mathrm{H}$. The structuring of organizational structure: a note. Administrative Science Quartely, 26, 470-474, 1981.

YIN, R. K. Estudo de caso: planejamento e métodos. Trad. Daniel Grassi. $2^{\underline{a}}$ ed. Porto Alegre: Bookman, 2001.

ZARIFIAN, P. Objetivo competência: por uma nova lógica. Trad. Maria Helena C. V. Trylinski. São Paulo: Atlas, 2001. , P. O modelo da competência. São Paulo : Editora Senac, 2003. 


\section{APÊNDICE}

\section{I - ROTEIRO NORTEADOR E DE CHECAGEM}

1) Minha atividade permite conversas com outros trabalhadores na organização durante o trabalho.

2) Tenho que seguir corretamente as instruções recebidas de forma a alcançar os objetivos sem pos sibilidade de modificações nos métodos.

3) O treinamento que recebo fornece-me apenas informações práticas para que eu realize meu trabalho dentro das normas determinadas.

4) A maior parte dos treinamentos que recebo trata apenas da atividade que realizo, não se preocupando em explicar as demais atividades realizadas na organização como um todo.

5) Meu supervisor monitora todas as atividades que realizo não permitindo ações autônomas.

6) Qualquer pessoa que passar pelo mesmo treinamento que eu estará apta a realizar o trabalho que realizo.

7) As atividades principais que devo realizar são pré-definidas pela organização do sistema ou pelo meu supervisor, independente de minha opinião.

8) Os cargos nesta organização são estáveis, sendo fácil reconhecer as relações hierárquicas.

9) Posso dar sugestões ao meu supervisor para melhorar a sistemática de execução de meu trabalho? Com que freqüência? Elas são implantadas?

10) Recebo e transmito informações apenas para meu supervisor?

11) Tenho tempo para conversar sobre assuntos diversos com meus colegas de trabalho durante o trabalho?

12) Preciso pedir permissão para realizar adaptações nas instruções que recebo para alcançar os objetivos esperados?

13) Meu supervisor preocupa-se com minhas motivações e expectativas sobre o trabalho, preocupando-se em manter um ambiente de trabalho sempre agradável? Frequência?

14) O treinamento que recebo enfoca a aprendizagem para identificação de problemas no decorrer do trabalho e suas possíveis soluções? Quantos?

15) Se sair do meu cargo atual, para alguém conseguir realizar o trabalho da mesma forma que eu o faço levará muito tempo?

16) Lido constantemente com situações inesperadas, não sendo possível definir previamente as atividades que irei desenvolver?

17) Recebo instruções expressas, porém tento realizar meu trabalho de forma a contentar quem está no poder em primeira instância e depois os pacientes?

18) As mudanças que ocorrem sobre a execução de meu trabalho surgem a partir das necessidades percebidas, por meio de tentativa e erro?

19) Preciso respeitar interesses políticos dos outros trabalhadores para alcançar meus objetivos?

20) Tenho que conhecer as relações de poder existentes na organização para melhorar minha comunicação e negociação com os demais trabalhadores e, conseqüentemente, a qualidade de meu trabalho?

21) Participo de diálogos com meus colegas expondo minhas idéias e buscando conhecer as opiniões dos demais?

22) Analiso, com o auxílio de colegas, situações que ocorreram na organização que causaram desconforto e/ou conflito, buscando entender o "porquê".

23) Meu superior trabalha como coordenador para auxiliar a integração e harmonia dos grupos de trabalho existentes na organização? Frequência?

24) Tenho autonomia para analisar o trabalho que realizo, identificando oportunidades e falhas e corrigindo-as? Frequência. 
25) Tenho autonomia para realizar projetos novos dentro da organização e alterar os projetos em andamento conforme as necessidades percebidas.

26) Comunico-me com todos na organização para melhorar meu trabalho, sem restrições?

27) Mantenho-me informado sobre os objetivos organizacionais, pois sei que eles interferem no meu trabalho?

28) Tenho disponibilidade(recursos e tempo) para buscar as informações necessárias para tomar uma decisão?

29) Estou preparado para lidar com situações cada vez mais complexas graças a experiência que estou adquirindo?

30) Auxilio na identificação de necessidades de aprendizagem e desenvolvimento de competências, e participo da formulação de planos para atendê-las? Frequência.

\section{II - ROTEIROS A, B e C}

\section{A- NATUREZA DO PROCESSO DE DECISÃO}

1. Você tem autonomia para reestruturar seu processo de trabalho? Em que proporção?

2. As decisões principais em relação à execução de seu trabalho cabem ao chefe, restando a você obedecê-las e respeitá-las?

3. Sua opinião é considerada como uma fonte de informação aos projetistas ob trabalho/ organização (pessoas capazes de mudar o sistema de gestão)? Em que sentido?

4. Há oportunidade para aceitar ou rejeitar ordens e pedidos de seus superiores, desde que se respeite as relações de poder instituídas na organização?

5. As modificações na organização de seu trabalho são planejadas ou acontecem naturalmente de acordo com a necessidade? Qual a sua influência no processo?

6. Frente ás situações de incerteza quanto aos meios e/ou quanto aos fins, você tem autonomia para atuar frente a elas? Com que freqüência ocorrem?

\section{B - APRENDIZAGEM ORGANIZACIONAL}

1. Há comunicação intra e entre áreas e pessoas no sentido de melhorar a execução do trabalho?

2. Há reflexão coletiva sobre as experiências vivenciadas. Se sim, como?

3. Há possibilidade de observar o trabalho dos demais envolvidos e aprender com eles?

4. Você considera que todos os sujeitos da área/organização estão em processo de aprendizagem individual?

5. Há na organização constante interação entre os sujeitos agentes para buscar de melhores condições de execução do trabalho?

6. Há atividades de formação que levam as pessoas a melhor lidar com imprevistos?

7. Há autonomia para os sujeitos resolverem os imprevistos? Em que momentos, com que freqüência? Como é registrado o aprendizado?

8. Há possibilidade de executar em circunstâncias incertas quebras da rotina prescrita? Em que momentos, com que freqüência?

9. Há ações para repassar informações repetitivamente entre os pares? Quais? Frequência? 


\section{C- APRENDIZAGEM INDIVIDUAL}

1. Quem e como se define o que se deve aprender?

2. Há ações no sentido de atender ao tempo e ao jeito de cada sujeito aprender? Enfim, releva-se particularidades?

3. Há conhecimento de sua parte do porquê e do para quê aprender o que aprende?

4. Há disponibilidade de tempo e recursos para reflexão sobre as experiências vivenciadas?

5. Há uma preocupação com o processo de feedback do que foi aprendido? Com que freqüência?

6. Há possibilidade de acesso a teorias/pesquisas a respeito da experiência vivenciada ou do treinamento realizado?

7. Há autonomia para realização de novas experiências frente a experiência adquirida em seu trabalho? Como?

8. Como se dá a avaliação do treinamento recebido? Você verifica ligação do aprendido com suas necessidades de aprendizagem? Frequência.

9. Qual a sua maior fonte de aprendizagem na organização? Como aprimora sua ação?

10. Os treinamentos recebidos tem implicado em mudanças no local de trabalho? Comente.

11. O que você acha do ciclo. Experiência, discussão da experiência, novos conceitos, testagem dos novos conceitos na prática, nova experiência? Como ele se dá?

12. Que fatores mais the impede de aprender na organização?

13. Como se dá a busca do saber, do saber-fazer e do saber-ser? Eles estão voltados para quê? Como se dá a vinculação do que se aprende com a sua realidade operacional? Quais são seus guias?

14. Como ou quem articula os aprendizados dos diversos enfermeiros? Como se dá este processo? 